\title{
De arbeidsmarkt naar opleiding en beroep tot 2002
}

\author{
Citation for published version (APA):
}

Researchcentrum voor Onderwijs en Arbeidsmarkt, ROA. (1997). De arbeidsmarkt naar opleiding en beroep tot 2002. Researchcentrum voor Onderwijs en Arbeidsmarkt, Faculteit der Economische Wetenschappen. ROA Reports No. 007 https://doi.org/10.26481/umarep.1997007

Document status and date:

Published: 01/01/1997

DOI:

10.26481/umarep.1997007

Document Version:

Publisher's PDF, also known as Version of record

\section{Please check the document version of this publication:}

- A submitted manuscript is the version of the article upon submission and before peer-review. There can be important differences between the submitted version and the official published version of record.

People interested in the research are advised to contact the author for the final version of the publication, or visit the DOI to the publisher's website.

- The final author version and the galley proof are versions of the publication after peer review.

- The final published version features the final layout of the paper including the volume, issue and page numbers.

Link to publication

\footnotetext{
General rights rights.

- You may freely distribute the URL identifying the publication in the public portal. please follow below link for the End User Agreement:

www.umlib.nl/taverne-license

Take down policy

If you believe that this document breaches copyright please contact us at:

repository@maastrichtuniversity.nl

providing details and we will investigate your claim.
}

Copyright and moral rights for the publications made accessible in the public portal are retained by the authors and/or other copyright owners and it is a condition of accessing publications that users recognise and abide by the legal requirements associated with these

- Users may download and print one copy of any publication from the public portal for the purpose of private study or research.

- You may not further distribute the material or use it for any profit-making activity or commercial gain

If the publication is distributed under the terms of Article $25 \mathrm{fa}$ of the Dutch Copyright Act, indicated by the "Taverne" license above, 


\section{De arbeidsmarkt naar opleiding en beroep tot 2002}

ROA-R-1997/7

Researchcentrum voor Onderwijs en Arbeidsmarkt

Faculteit der Economische Wetenschappen en Bedrijfskunde Universiteit Maastricht

Maastricht, oktober 1997 
Niets uit deze uitgave mag worden verveelvoudigd en/of openbaar gemaakt door middel van druk, fotocopie, microfilm, of op welke wijze ook, zonder voorafgaande schriftelijke toestemming van de directeur van het Researchcentrum voor Onderwijs en Arbeidsmarkt. In geval van overname van het data-materiaal moet telkens als bron worden vermeld: "Researchcentrum voor Onderwijs en Arbeidsmarkt" of "ROA". Van publicaties waarin gebruik wordt gemaakt van gegevens uit dit rapport ontvangen wij gaarne een exemplaar.

Hoewel de grootst mogelijke zorg is besteed aan de inhoud van dit rapport, kan het ROA in generlei opzicht verantwoordelijkheid op zich nemen voor eventuele onvolledigheden of onjuistheden. 


\section{Inhoud}

Ten geleide

Resumé $\quad$ V

Doel en opzet van de arbeidsmarktprognoses $\quad$ XI

1 De arbeidsmarkt in vogelvlucht 1

1.1 De verwachte arbeidsmarktontwikkeling 1

1.2 Werkgelegenheidsontwikkeling naar bedrijfssector 3

1.3 Werkgelegenheidsontwikkeling naar beroepssector 5

1.4 Werkgelegenheidsontwikkeling naar opleidingsniveau 6

1.5 Arbeidsmarktperspectieven naar opleidingsniveau 7

2 Ontwikkelingen op de arbeidsmarkt 1997-2002 11

2.1 Uitbreidingsvraag 11

2.2 Vervangingsvraag $\quad 15$

2.3 Baanopeningen 21

2.4 Arbeidsmarktinstroom $\quad 25$

2.5 Substitutie-effecten 28

3 De aansluiting tussen onderwijs en arbeidsmarkt 31

3.1 Huidige aansluitingsproblemen 31

3.2 Conjunctuurgevoeligheid en uitwijkmogelijkheden 41

3.3 Arbeidsmarktperspectieven voor schoolverlaters 44

$\begin{array}{ll}3.4 \text { Toekomstige knelpunten in de personeelsvoorziening } & 47\end{array}$

4 Aanpassingsprocessen op de arbeidsmarkt 51

4.1 Inleiding 51

4.2 Gevolgen van discrepanties tussen vratg en aanbod 52

4.3 Verwachte veranderingen in de aard van het werk 57

4.4 Structurele aanpassingen en mogelijkheden voor beleid 67

5 Besluit: veranderende perspectieven op de arbeidsmarkt 8,3

Enkele centrale begrippen 


\section{Ten geleide}

Dit rapport met afzonderlijk uitgebrachte Statistische Bijlage vormt de vierde versie van het tweejaarlijkse overzichtsrapport dat het Researchcentrum voor Onderwijs en Arbeidsmarkt (ROA) uitbrengt in het kader van het Project Onderwijs-Arbeidsmarkt (POA). Het POA-project wordt momenteel gefinancierd door het Ministerie van Onderwijs, Cultuur en Wetenschappen, het Landelijk Bureau Arbeidsvoorziening, het Landelijk Dienstverlenend Centrum voor studie- en beroepskeuzevoorlichting (LDC), het Ministerie van Sociale Zaken en Werkgelegenheid en het Ministerie van Landbouw, Natuurbeheer en Visserij.

Het POA-project heeft als doel inzicht te verschaffen in de huidige en de toekomstige positie van de verschillende beroeps- en opleidingscategorieën op de arbeidsmarkt. Hierbij staan de verwachte ontwikkelingen op de middellange termijn centraal. Er is voor deze tijdshorizon gekozen, om degenen die op dit moment voor een studiekeuzebeslissing staan, zo goed mogelijk te kunnen informeren over de arbeidsmarktsituatie op het moment dat zij na het afronden van hun opleiding instromen op de arbeidsmarkt. Deze voorlichtingsfunctie wordt in het bijzonder vervuld door het verwerken van de arbeidsmarktinformatie uit het POA-project in de voorlichtingsproducten van het LDC. Zo is deze informatie opgenomen in de op CD-ROM verkrijgbare voorlichtingsproducten die zijn uitgebracht in de Traject-reeks, de reeks Straks Studeren en op de internet-site www.werk.net van de Arbeidsvoorzieningsorganisatie. Geheel toegesneden op de verspreiding van de arbeidsmarktinformatie van het ROA ten behoeve van voorlichtingsdoelen zijn de LDC-publicaties Kansen op werk 2002, Arbeidsmarktperspectieven van opleidingen en beroepen en de Arbeidsmarktkrant van Nederland.

Het voorliggende rapport, heeft daarentegen als belangrijkste doelgroep degenen die beleidsmatig betrokken zijn bij de aansluiting tussen het onderwijs en de arbeidsmarkt. Daarbij is het rapport in het bijzonder bedoeld voor de overheid, de Arbeidsvoorzieningsorganisatie, de sociale partners en het onderwijsveld.

De komende jaren zal er naar gestreefd worden de kwaliteit van de voortgebrachte arbeidsmarktinformatie verder te verbeteren en de bruikbaarheid van de informatic voor de beoogde doelgroepen te vergroten*. Daarbij is het in het bijzonder van belang dat onlangs de aanzet is gegeven tot het opzetten van een enquête onder schoolverlaters, die betrekking heeft op universitair opgeleiden. De komst van deze W( -Monitor zal het mogelijk maken de actuele aansluitingsproblemen op de arbeidsmarkt in katrt te brengen over de volle breedte van het initieel onderwijs. Bovendien zal met behulp van deze databron meer inzicht kunnen worden gegeven in de wijze waarop de voorspelde arbeidsmarktperspectieven zich voor de verschillende opleidingstypen naar verwachting zullen manifesteren.

- I it evaluatiestudies van eerdere prognoses blijkt dat de arbeidsmarktperspecticven naar opleidings type achteraf vrij goed voorspeld bleken te zijn. L. Borghans. P. van Fijs, W. Smits, frahuate arbeids markt prognoses naar opleiding en beroep tot 1994, ROA-R-1996/9. Maastricht. 1996. 
In het voorliggende rapport wordt slechts in beperkte mate ingegaan op de gehanteerde onderzoeksmethoden, de gehanteerde classificaties enz. Daarvoor wordt verwezen naar de specifieke werkdocumenten en research-memoranda van het ROA. In het werkdocument Methodiek arbeidsmarktprognoses en -indicatoren 1997-2002 (ROAW-1997/6) wordt een totaaloverzicht gegeven van de voor deze versie van het tweejaarlijkse rapport gebruikte methodieken. Er zal in dit rapport wel kort worden ingegaan op de gebruiksdoelen van de prognoses en een globaal overzicht worden gegeven van het gebruikte prognosemodel. Achterin het rapport zijn enkele centrale begrippen nader omschreven, waarbij verwijzingen zijn opgenomen naar de publicaties waarin over het desbetreffende aspect nadere informatie is te vinden.

Bij de samenstelling van het rapport is in belangrijke mate gebruik gemaakt van de Enquête Beroepsbevolking van het Centraal Bureau voor de Statistiek (CBS). Op basis van een samenwerkingsverband met het CBS zijn de gebruikte gegevens door ROAmedewerkers samengesteld bij het CBS. Op het publiceren van deze gegevens heeft het CBS enkele restricties gesteld. Mede in verband hiermee worden er geen afzonderlijke gegevens gepubliceerd voor enkele kleine beroepsgroepen en opleidingstypen met minder dan 2.500 werkenden.

Het rapport bestaat uit vijf hoofdstukken. In hoofdstuk 1 wordt een globaal overzicht gegeven van de ontwikkelingen die voor de periode 1997-2002 zijn te verwachten op de arbeidsmarkt. Daarbij wordt verbijzonderd naar bedrijfssector, beroepscategorie en opleidingsniveau. Tevens wordt een vergelijking gemaakt met de ontwikkelingen in de afgelopen jaren. De in dit hoofdstuk gepresenteerde informatie heeft betrekking op een relatief hoog aggregatieniveau. Verdere verbijzonderingen volgen in de latere hoofdstukken. In hoofdstuk 2 worden voor de jaren 1997-2002 de meest saillante arbeidsmarktontwikkelingen naar opleiding en beroep in beeld gebracht. Hoofdstuk 3 gaat nader in op achtereenvolgens de actuele ansluitingsproblematiek op de arbeidsmarkt, de conjuncturgevoeligheid van de werkgelegenheid in relatie tot de uitwijkmogelijkheden op de arbeidsmarkt, de arbeidsmarktperspectieven voor schoolverlaters en de verwachte knelpunten in de personeelsvoorziening in de verschillende bedrijfssectoren. Ioofdstuk 4 gatat in op de betekenis van de verwachte arbeidsmarktontwikkelingen voor zowel de aanpassingen op de korte termijn, als voor de aanpassingen op de langere termijn en de mogelijkheden voor beleid. Bovendien wordt in dit hoofdstuk ingegaan op de implicaties van de verschuivingen in de beroepenstructuur voor de a ard en het niveau van het werk, de vereiste vaardigheden en de fysieke belasting die het werk met zich mee brengt. Ten slotte wordt in hoofdstuk 5 de betekenis van de verwachte arbeidsmarktontwikkelingen nader belicht vanuit een aantal beleidsmatige invalshoeken. Er wordt respectievelijk ingegaan op de knelpunten in de personeelsvoorziening, de arbeidsmarktperspectieven aan de onderkant van de arbeidsmarkt, de arheidsmarktperspectieven voor allochtonen, de opleidingen met een hoge instroom en slechte arbeidsmarktperspectieven, de veranderingen in het onderwijsanbod en de macro-doelmatigheid datarvan en het scholingsbeleid met betrekking tot het potentiële abridsalanbod.

De projectleiding van het POA-project is in handen van dr. A. de Grip en dr. L. Borghans. Aan de huidige versie van het overzichtsrapport en de bijhehorende Statistische Bijlage is meegewerkt door drs. J. Delmee, S. Dijksman, prof.dr. J.A.M. Heijke. drs. J. B. van Loo, 
drs. A.G.M. Matheeuwsen, J.M.J.A. Pisters, drs. W. Smits, H. Schonk, drs. M. de Steur en drs. E.J.T.A. Willems.

Onze dank gaat uit naar de leden van de begeleidingscommissie voor hun deskundige en intensieve begeleiding van het project. Deze commissie bestaat uit de volgende leden: prof.dr. J.L. Peschar (voorzitter; Rijksuniversiteit Groningen), drs. J.W. Altena (Centraal Bureau voor de Statistiek), drs. A. Bouman (Landelijk Bureau voor de Arbeidsvoorziening), H. Daale (Noordelijke Hogeschool Leeuwarden), drs. E. Janissen (LDC), drs. J. Lint (Ministerie van Landbouw, Natuurbeheer en Visserij), drs. H.J. Roodenburg (Centraal Planbureau), drs. J.J. Smit (Ministerie van Sociale Zaken en Werkgelegenheid), drs. R. Thönissen (Ministerie van Economische Zaken), drs. B.T.M. Verlaan (Ministerie van Onderwijs, Cultuur en Wetenschappen), drs. J.P. Vosse (Organisatie voor Strategisch Arbeidsmarktonderzoek), drs. M. Wegerif (Landelijk Bureau voor de Arbeidsvoorziening) en drs. G.R. de Wit (LDC).

Maastricht, oktober 1997

Prof.dr. J.A.M. Heijke

Directeur 


\section{Resumé}

\section{Toekomstige arbeidsmarktperspectieven}

- Voor de periode 1997-2002 wordt een gemiddelde jaarlijkse groei van de werkgelegenheid verwacht van $1,7 \%$ per jaar, tegenover $1,4 \%$ in de periode $1992-1996$. Voor de komende jaren wordt een gemiddelde jaarlijkse uitstroom van werkenden verwacht van 3,3\%. In de afgelopen jaren bedroeg deze uitstroom jaarlijks 3,0\% van het aantal werkenden. Er zal de komende vijf jaar dus sprake zijn van een toename van zowel de groei van de werkgelegenheid als de arbeidsmarktuitstroom van werkenden. Tegenover deze toename van de vraag naar nieuwkomers op de arbeidsmarkt staat een afname van de jaarlijkse arbeidsmarktinstroom van schoolverlaters van $5,6 \%$ in de afgelopen jaren naar 4,2\% in de jaren 1997-2002.

- Deze ontwikkelingen wijzen op een sterke omslag in de arbeidsmarktsituatie in de loop van de jaren negentig, die deels in de actuele situatie reeds tot uiting komt. Door aan de ene kant het aantrekken van de werkgelegenheidsgroei en de toename van de arbeidsmarktuitstroom van werkenden en aan de andere kant de teruglopende instroom van schoolverlaters op de arbeidsmarkt zullen de arbeidsmarktperspectieven voor schoolverlaters de komende jaren duidelijk verbeteren.

- Eerdere prognoses, die betrekking hadden op de periode 1995-2000, wezen al in de richting van duidelijk verbeterende arbeidsmarktperspectieven voor met name hoger opgeleiden. Op grond van de huidige prognoses mag verwacht worden dat deze tendens zich voortzet en dat deze verbetering zich ook voor lagere oplejdingsniveaus zal aftekenen. Zo verbeteren de arbeidsmarktperspectieven voor het $\mathrm{MBO} /$ leerlingwezen en het $\mathrm{HAVO} / \mathrm{VWO}$, terwijl ook aan de onderkant van de arbeidsmarkt het arbeidsmarktperspectief voor diverse opleidingen verletert. Al met al wordt voor driekwart van de bijna 100 onderscheiden opleidingstypen een goed tot zeer goed arbeidsmarktperspectief verwacht.

- Op de verschillende opleidingsniveaus bestaan er wel sterk uiteenlopende arbeidsmarktperspectieven. Met uitzondering van het basisonderwijs komen er op elk opleidingsniveau zowel opleidingen met goede tot zeer goede perspectieven als opleidingen met matige tot slechte arbeidsmarktperspectieven voor. Wel worde op HBO- en WO-niveau voor bijna alle opleidingstypen een goed tor zeer goed arbeidsmarktperspectief verwacht. Ook op MBO/leerlingwezen-nivealu word voor veel opleidingstypen een gunstig perspectief verwacht. Een gedetailleerd overzicht van de arbeidsmarktperspectieven is te vinden in tabel 3.27 van de stalistische Bijlage.

\section{Knelpunten in de personeelsvoorziening}

- Hoewel de komende jaren vrijwel alle bedriffsectoren met grote knelpunten in de. personeelsvoorziening zullen worden geconfronteerd, zullen de grootste knelpunten zich naar verwachting voordoen in de rakelijke dienstvertening. de gerond- 
heidszorg en de overheidssector. Daarbij gaat het vooral om knelpunten bij de werving van hoger opgeleiden, al worden in bepaalde sectoren ook zeer grote knelpunten in de personeelsvoorziening verwacht op $\mathrm{MBO}$ /leerlingwezen-niveau in de richtingen procestechniek, operationele techniek en horeca. Een gedetailleerd overzicht van de verwachte knelpunten in de personeelsvoorziening naar bedrijfssector is te vinden in tabel 1.13 van de Statistische Bijlage.

\section{De onderkant van de arbeidsmarkt}

- De arbeidsmarktperspectieven voor de laag opgeleiden blijven duidelijk achter bij die van de middelbaar en hoger opgeleiden. Toch is er een aantal VBO-opleidingen waarvoor de arbeidsmarktperspectieven goed zijn. De oorzaak voor dit gunstige arbeidsmarktperspectief ligt geheel aan de aanbodkant. Steeds minder leerlingen betreden de arbeidsmarkt met alleen een VBO-diploma, terwijl bovendien veel van hen na enkele jaren alsnog een diploma op MBO/leerlingwezen-niveau behalen. Andere ontwikkelingen laten echter zien dat de positie van deze laag geschoolden niet zonder meer rooskleurig genoemd kan worden. De beschikbare baanopeningen voor lager opgeleiden zijn vooral het gevolg van de hoge arbeidsmarktuitstroom van laag geschoolden op relatief jonge leeftijd. Deze uitstroom creëert weliswaar een vervangingsvraag voor schoolverlaters met een lagere opleiding, maar als de situatie op de arbeidsmarkt in dit opzicht niet verandert, hebben zij slechts een perspectief op een betrekkelijk kortstondig verblijf op de arbeidsmarkt. Alleen door verder te leren via bijvoorbeeld het leerlingwezen kan deze categorie schoolverlaters het ongunstige langere-termijn-perspectief ontlopen.

- Ongeschoolden komen steeds vaker terecht in functies waarvoor bepaalde vaardigheden vereist zijn. Daarbij gaat het vooral om communicatieve vaardigheden. Deze tendens leidt tot een toenemende spanning tussen de vereiste vaardigheden en de competenties van de ongeschoolden. Deels zullen zij deze achterstand kunnen compenseren door werkervaring, mar deels duidt dit ook op een evidente scholingsbehoefte.

\section{Allochtonen}

- Allochtone arbeidskrachten hebben op basis van hun opleidingsachtergrond een duidelijk minder goed arbeidsmarktperspectief dan de gemiddelde beroepsbevolking in Nederland. Wel wordt verwacht dat allochtonen ook zullen profiteren van de goede arbeidsmarktperspectieven die voor veel opleidingstypen worden verwacht. Datarbij bestaan er tussen de diverse groepen allochtonen echter grote verschillen. Turken en Marokkanen zullen het minst profiteren van deze betere arbeidsmarktperspectieven. Dit komt met name doordat zij vaak een lage opleidingsachtergrond hebhen walarvoor de werkgelegenheid krimpt. Surinamers en Antillianen hebben datrentegen een wat beter perspectief. Van de allochtonen uit landen die genoemd worden in de Wet Bevordering Arbeidsdeelname Allochtonen (WBEAA) blijken atbeidskrachten afkomstig uit het voormalige Joegoslavië, vooral door hun hoge gemiddelde opleidingsniveau, de beste perspectieven te hebben.

- Allochtonen afkomstig uit niet-WBEAA-landen hebben opmerkelijk genoeg gemid- 
deld genomen iets betere perspectieven dan autochtone Nederlanders. Dit geldt met name voor allochtonen afkomstig uit de overige E.U.-landen, Oost-Europa en de Verenigde Staten. Aangenomen mag worden dat hier sprake is van een 'pull effect'. Opleidingstypen met goede arbeidsmarktperspectieven trekken mensen uit deze landen aan.

\section{Beroependomein en niveau van het werk}

- De mate waarin werk wordt gevonden in de eigen vakrichting neemt duidelijk toe naarmate het opleidingsniveau hoger is. Zo werkt op VBO-niveau momenteel slechts $25 \%$ van de werkenden in een vakspecifiek beroepsterrein, tegenover $51 \%$ op HBO-niveau en $55 \%$ op WO-niveau. Voor alle opleidingsniveaus wordt de komende jaren een verschuiving van de werkgelegenheid verwacht nat beroepen buiten het vakspecifieke domein. Daarbij zijn de verschuivingen het grootst bij universitair opgeleiden. Waarschijnlijk zijn deze verschuivingen deels toe te schrijven aan 'nieuwe' beroepen, waarvoor de op deze beroepen gerichte opleidingen nog een te geringe arbeidsmarktinstroom van schoolverlaters hebben om in de vraag te voorzien.

- Het percentage werkenden dat werk heeft beneden het gevolgde opleidingsniveau neemt eveneens toe met de hoogte van het opleidingsniveau. Van de middelbaar opgeleiden werkt slechts $7 \%$ beneden het eigen opleidingsniveau, terwijl van de HBO'ers $24 \%$ en van de WO'ers $32 \%$ werk heeft op een, gezien hun opleidingsachtergrond, te laag functieniveau. Dit beeld zal de komende jaren vrijwel stabiel blijven. Alleen bij het WO zal het deel van de werkenden dat werkzaam is beneden het eigen niveau stijgen.

\section{Studiekeuze en onderwijsbeleid}

- Opvallend is dat bij de opleidingen waarvoor de arbeidsmarktperspectieven matig of slecht zijn, veelal sprake is van een (erg) hoge arbeidsmarktinstroom. Beperking van deze hoge instroom lijkt derhalve een belangrijke bijdrage te kunnen leveren alan het verbeteren van de arbeidsmarktperspectieven voor deze opleidingen.

- Studiekeuzevoorlichting is het belangrijkste beleidsinstrument om dergelijke arbeidsmarktdiscrepanties te beperken. Dit temeer daar er alanwijzingen zijn dal leerlingen die voor een opleiding met een minder gunstig arbeidsmarktperspectief kiezen, bij hun studiekeuze ook alternatieven met goede perspecticven heblen overwogen. De mate warin het keuzegedrag van leerlingen zou moeten veranderen om vraag en aanbod voor het desbetreffende opleidingstype in evenwicht te brengen, loopt echter sterk uiteen van $8 \%$ bij MBO/LLW bande/ 10 t $65 \%$ hij $/ / 130 / \mathrm{pe}$. soneelswerk.

- Om de zeer extreme verschillen tussen vraag en aanbod op de arbeidsmarka ke beperken zou ook een numerus fixus voor de onderwijsinstroom kunnen worden ingesteld. Bij een dergelijke arbeidsmarktfixus dient te worden vermeden dat de aansluitingsproblemen op de arbeidsmarkt worden verschoven naar andere opleidingen. Een goed functionerende arbeidsmarkt is slechts gebaat bij ecen lxepcrkt gebruik van de arbeidsmarktfixus. Als een arbeidsmarktfixus voor een bepaalde 
opleiding gedurende lange tijd wordt ingesteld, ontneemt deze fixus de arbeidsmarkt haar aanpassingsvermogen.

- Omgekeerd kan het onderwijsbeleid ook gericht worden op het bevorderen van de instroom in opleidingstypen met goede of zeer goede arbeidsmarktperspectieven. Daarbij kan gedacht worden aan het verbeteren van de geografische spreiding van het onderwijsaanbod voor de desbetreffende opleidingen of de introductie van een opleidingsvariant die op dat moment nog niet wordt aangeboden. Nieuw aanbod van opleidingen zal vooral baat hebben wanneer er leerlingen worden aangetrokken die anders een opleiding zouden kiezen met duidelijk slechtere perspectieven. Een goed voorbeeld hiervan zijn opleidingstypen die meer meisjes weten aan te trekken voor de technische opleidingen die (zeer) goede arbeidsmarktperspectieven bieden.

- Naast het arbeidsmarktperspectief voor de komende jaren, kan het onderwijsbeleid ook de structurele positie van opleidingen als richtlijn nemen. Daarbij kan gedacht worden aan het verbreden van het curriculum van opleidingen met een beperkt beroependomein warvoor de werkgelegenheid bovendien erg conjunctuurgevoelig is. Ook bij nieuwe specialistische opleidingen is het van belang om te toetsen of de voordelen van de nieuwe specialisatie opwegen tegen de risico's die men met een dergelijke specialisatie op de arbeidsmarkt loopt.

\section{Scholingsbeleid}

- Gezien de omvang van de voor de komende jaren verwachte knelpunten in de personeelsvoorziening voor een groot atantal opleidingstypen en de beperkte mogelijkheid om hierop in te spelen door verschuivingen in de arbeidsmarktinstroom vanuit het initiële onderwijs, is het evident dat een belangrijke impuls zal moeten worden gegeven aan het bij- of omscholen van het beschikbare arbeidsanbod.

- In de eerste plaats zou daarbij kunnen worden gedacht aan het omscholen van het aanbodoverschot bij de opleidingen met een matig tot slecht arbeidsmarktperspecetief. Datarbij moet bedacht worden dat de grote knelpunten in de personectsvoorzicning zich vark voordeen bij de hoger opgeteiden, terwijl de alanbodowerschotten zich concentreren bij de lager opgeleiden. Desalniettemin zijn er, zoals gezegd, hij vecl opleidingen met minder gunstige arbeidsmarktperspectieven ter dege reële alternatieven met goede perspectieven.

- Ien belangrijle doelgroep voor het bij- of omscholingsbeleid is ongetwijfeld de groep langdurig werklozen. Het is opmerkelijk dat bijna de helft van de langdurig werklozen een opleidingsachtergrond heeft met goede arbeidsmarktperspectieven. Het gital hier om 110.000 personen. Voor een zestal opleidingen op VBO-, MBO- of IIBO-niveatu zou het inzetten van een deel van de langdurig werklozen de verwachte a anbodtckorten in principe kunnen roorkomen.

- Ten slotte zou ook het stimuleren van de arbeidsparticipatie een belangrijke bijdrage kunnen leveren aan het workomen van de verwachte knelpunten. Voor eenderde van de opleidingstypen walarvor grote tot zeer grote knelpunten in de personeelsvorziening worden verwacht. zou echter zelfs een volledige inzet van de niet-par- 
ticiperenden met de desbetreffende opleidingsachtergrond nog ontoereikend zijn om in de vraag te voorzien. Voor een aantal andere opleidingstypen zou de non-participatie met meer dan de helft moeten worden teruggebracht. 


\section{Doel en opzet van de arbeidsmarktprognoses}

\section{Doelgroepen}

Dit rapport, met afzonderlijke uitvoerige Statistische Bijlage, biedt een overzicht van de door het Researchcentrum voor Onderwijs en Arbeidsmarkt (ROA) opgestelde prognoses van de ontwikkelingen op de Nederlandse arbeidsmarkt in de periode 1997-2002. Het gepresenteerde overzicht heeft als doel inzicht te verschaffen in de toekomstige arbeidsmarktpositie van beroeps- en opleidingscategorieën. De prognoses worden elke twee jaar herhaald voor een nieuwe periode van viff jaar. De volgende versie van dit rapport zal derhalve in 1999 verschijnen. De Statistische Bijlage wordt echter jaarlijks geactualiseerd.

Een belangrijke doelgroep van de prognoses wordt gevormd door jongeren die voor de keuze van een (vervolg) opleiding staan. De prognoseresultaten stellen hen in stat hun keuze te funderen op de arbeidsmarktperspectieven die de verschillende opleidingen bieden op de middellange termijn. Deze voorlichtingsfunctie wordt, zoals in het Ten geleide reeds werd opgemerkt, in het bijzonder vervuld door het Landelijk Dienstverlenend Centrum voor studie- en beroepskeuzevoorlichting (LDC). Daarnaast is de geboden informatie bedoeld voor het onderwijsbeleid. Daarbij kan vooral gedacht worden aan onderwijsinstellingen en hun financiers die overwegen nieuwe opleidingen te beginnen of bestaande aan te passen. Eenderde doelgroep zijn de werkgevers voor wic de prognose-uitkomsten aanwijzingen geven waar zich in de toekomst problemen in de personeelsvoorziening zullen voordoen, zodat zij hierop kunnen anticiperen. In de vierde plaats zijn de arbeidsmarktprognoses bedoeld voor het arbeidsvoorzieningsbeleid. Met name voor het in dit verband gevoerde scholingsbeleid kunnen de prognoses een belangrijke signaalwerking hebben. Daarbij moet wel de kanttekening worden gemaakt dat de scholing van werkzoekenden doorgaans een kortere doorlooptijd heefi dan de opleidingen in het initiële onderwijs. In het Regionaal Arbeidsmarkt Informatiesysteem Limburg (RAIL) dat wordt ontwikketd ten behoeve van het scholingsbeleid van Arbeidsvoorziening Limburg worden daarom korte-termijn-arbeidsmarktprognoses opgesteld die overigens vortbouwen op de in dit rapport gepresenteerde middellange-termijn-prognoses. Ten slotte zijn de prognoses bedoeld vorl het arbeidsmarktbeleid in ruime zin. Daarbij kan gedacht worden aan o.a. het doelgroepenbeleid en het arbeidsmarktbeleid ten aanzien van de onderkant van de arlecidsmarkt.

\section{Prognosemodel}

Bij het maken van de arbeidsmarktprognoses is uitgegaan van een stronmcijfer-alanpak. Bij deze aanpak worden prognoses gemaakt van de stromen van en naar de arbeidsmarkt in een bepaalde toekomstige periode. Deze benadering heeft als voordeel dat de processen in kaart worden gebracht die van belang zijn voor de ontwikkeling van vraag en aanbod op de arbeidsmarkt. De prognoses worden opgesteld voor in totial 123 
Figuur 1

Globale opzet prognosemodel

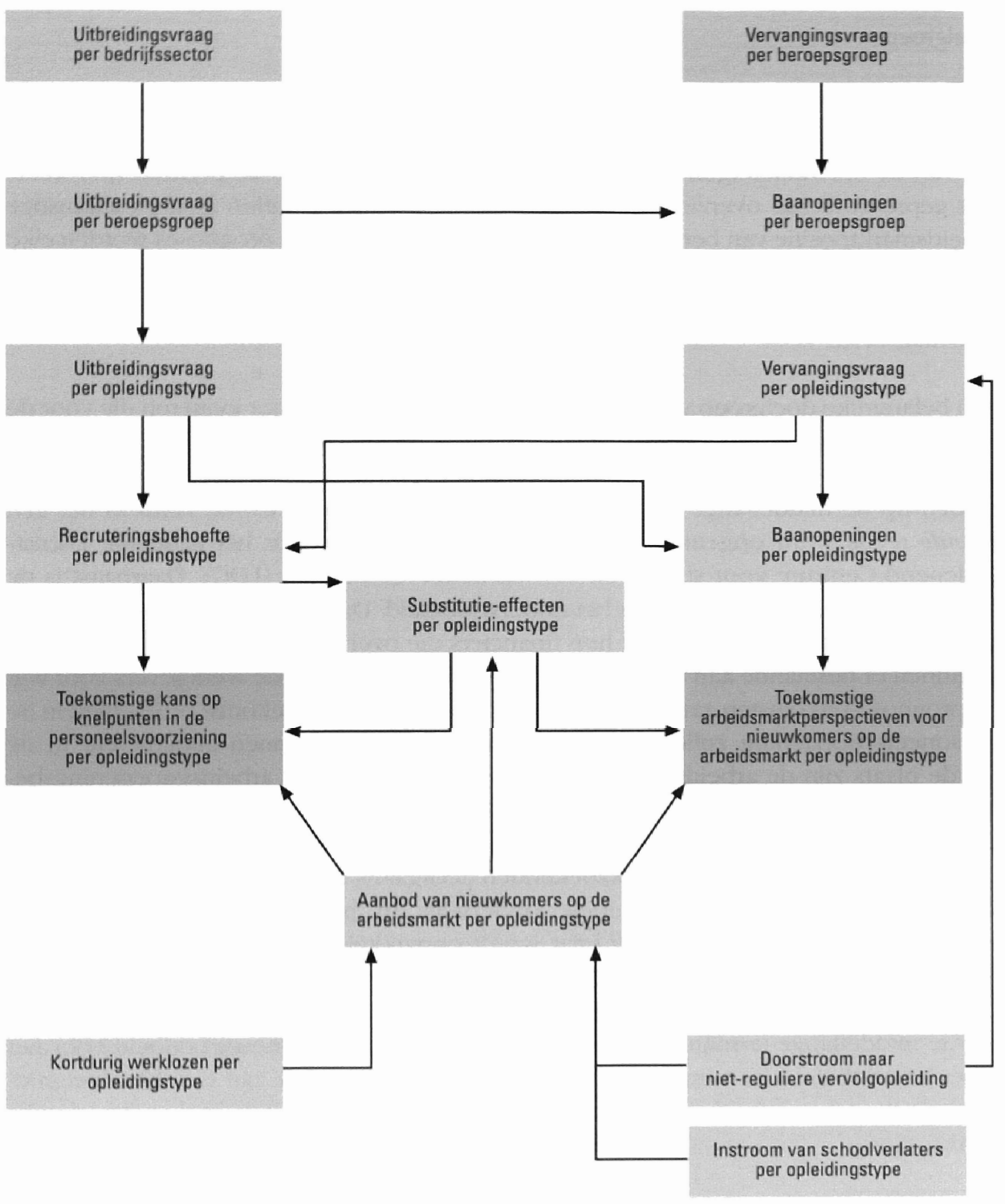


beroepsgroepen en 98 opleidingstypen, gespreid over de volle breedte van de arbeidsmarkt*.

Figuur 1 geeft een schematisch overzicht van het prognosemodel**. Een stroomgrootheid die van belang is voor de vraagzijde van de arbeidsmarkt is de uitbreidingstraag, die de ontwikkeling weergeeft van de werkgelegenheid in een bepaalde beroepsgroep of voor een bepaald opleidingstype. De prognoses van de uitbreidingsvraag zijn gebaseerd op de werkgelegenheidsprognoses voor bedrijfssectoren van het Centraal Planbureau. Voor de jaren 1997 en 1998 is uitgegaan van de korte- termijn prognoses afkomstig uit het Centraal Economisch Plan 1997. De prognoses voor 1999 en 2000 zijn gebaseerd op de middellange-termijn prognoses volgens het gunstig scenario uit het Centraal Economisch Plan 1996. Kenmerkend voor dit scenario zijn een stabiele hoge economische groei, weinig inflatoire spanningen en een rustige valutamarkt. De keuze voor dit scenario is ingegeven door de constatering dat de Nederlandse economie zich momenteel al op een groeipad bevindt dat in positieve zin afwijkt van het gunstig scenario. Voor de jaren 2001 en 2002 is uitgegaan van een voortzetting van de werkgelegenheidsontwikkeling volgens dit scenario.

In aansluiting daarop worden door het ROA prognoses gemaakt van de verschuivingen in de beroepenstructuur binnen de onderscheiden bedrijfssectoren. Hierdoor kan er rekening gehouden worden met het feit dat binnen een bedrijfssector bepaalde beroepsgroepen zich sneller ontwikkelen dan andere. Vervolgens wordt bepaald welke implicaties de voorspelde groei van de verschillende beroepsgroepen heeft voor de uitbreidingsvraag per opleidingstype. Hierbij wordt rekening gehouden met het optreden van verschuivingen in de opleidingenstructuur van beroepsgroepen. De uithreidingsvraag per opleidingstype heeft betrekking op het aantal personen met een bepaalde opleidingsachtergrond, dat werkgevers zouden willen aannemen om te kunnen voorzien in een grotere vraag naar goederen en diensten. De feitelijke ontwikkeling van het aantal werkenden per opleidingstype zal hiervan doorgaans van afwijken door de mede door de ontwikkeling van het arbeidsaanbod veranderende schaarsteverhoudingen en de als gevolg daarvan optredende substitutieprocessen.

Naast uitbreidingsvraag is er op de arbeidsmarkt sprake van vervangingsvraag door - al dan niet vervroegde - pensionering, arbeidsongeschiktheid, tijdelijke terugtreding van de arbeidsmarkt, beroepsmobiliteit, e.d. Er wordt overigens alleen van vervangingsvralag gesproken voor zover het vertrek van een werknemer ook daadwerkelijk leidt tot vraag naar een nieuwkomer. Als het vertrek van een arbeidskracht gebruikt wordt om een werkgelegenheidskrimp te effectueren, is er derhalve geen sprake van vervangingsvraag. Deze uitstroom is immers niet relevant voor nieuwkomers. Dit betekent dat nict de volledige arbeidsmarktuitstroom daadwerkelijk leidt tot vervangingsvraag.

- Zowel het aantal onderscheiden beropsgroepen als het aantal opleidingstypen is aanzicnlijk groter dan in het vorige rapport waarin 93 beroepsklassen en 79 opleidingstypen werden onderseheiden. Bovendien sluit de nieuwe indeling beter aan bij de feitelijke segmentatic van de arbeidsmarkt. \%ic. H. Heijke. A. Matheeuwsen en F. Willems, Chestering educational calegories in a beterogenerns labour market. ROA Maastricht (verschijnt binnenkort).

* Voor een uitgebreide toelichting wordt verwezen naar Borghans et al., Methedick arbeidsmarke prognoses en -indicatoren 1997-2002, ROA-W-1997/6. Maastricht, 1997. 
Bovendien is er een belangrijk verschil tussen de vervangingsvraag per beroepsgroep en per opleidingstype. De beroepsmobiliteit is namelijk wel van invloed op de vervangingsvraag per beroepsgroep, maar heeft geen effect op de vervangingsvraag per opleidingstype. Het veranderen van beroep heeft immers geen gevolgen voor de opleidingsstructuur van de werkgelegenheid. Daarentegen kan het naast een baan afronden van een vervolgopleiding betekenen dat een werkende in feite uitstroomt naar een ander opleidingstype. In dat geval is er sprake van een vervangingsvraag bij het opleidingstype waartoe de vooropleiding van deze werkende wordt gerekend.

Bij toename van de werkgelegenheid vormen de uitbreidingsvraag en de vervangingsvraag tezamen de baanopeningen voor nieuwkomers op de arbeidsmarkt. Bij krimpende werkgelegenheid kan er alleen sprake zijn van baanopeningen uit hoofde van vervangingsvraag.

Tegenover de totale vraag naar nieuwkomers staat het verwachte aanbod van nieuwkomers, bestaande uit de toekomstige instroom van schoolverlaters en de doorstroom naar niet-reguliere vervolgopleidingen in de prognoseperiode en het nog boven de markt zwevende aanbod van kortdurig werklozen aan het begin van deze periode. Verondersteld wordt dat langdurig werklozen, die langer dan een jaar op zoek zijn naar werk, geen serieuze concurrenten meer vormen voor schoolverlaters. De prognoses van de instroom van schoolverlaters op de arbeidsmarkt hebben als uitgangspunt de Referentieraming 1997 van het Ministerie van Onderwijs, Cultuur en Wetenschappen met betrekking tot de verwachte uitstroom uit het initiële onderwijs. Door het ROA zijn deze prognoses nader verbijzonderd en angevuld met prognoses van de doorstroom naar het niet-reguliere onderwijs.

Door de verwachte vraag- en aanbodstromen met elkaar te confronteren wordt per opleidingstype een indicatie verkregen van de toekomstige arbeidsmarkiperspectieven vorr nieuwkomers op de arbeidsmarkt. De desbetreffende indicator geeft aan welke vraag-aanbod-discrepantic er per opleidingstype te verwachten is. Een aanbodoverschot impliceert echter niet vanzelfsprekend dat de desbetreffende groep werkloos zal worden en cen atanbodtekort betekent niet automatisch dat er sprake zal zijn van onvervulde vacatures. Het is immers ook mogelijk dat werkgevers in het eerste geval hun cisen aanpassen en mensen aannemen met een hogere opleidingsachtergrond dan aanvankelijk gevaangd werd. Schoolverlaters met een opleiding waarvoor het aanbod de vratag overtreft ervaren in een dergelijke situatie een verslechtering van hun positie doordat zij bijvoorbeeld vaker beneden hun niveau moeten werken, een minder goed contrat krijgen, slechter beloond worden of vaker genoegen moeten nemen met parttime werk, kerwijl men liever een full-time betrekking had*. Omgekeerd zal bij een tekortschietend a anbod de positie van schoolverlaters verbeteren. Deze hoeven in dat geval minder valak genoegen te nemen met een functie op een lager niveau, een lagere beloning e.d.

* M.II. Wieling, L. Borghans, Aansluitingsproblemen en ampassingsprocessen op de arbeidsnarkt, in:

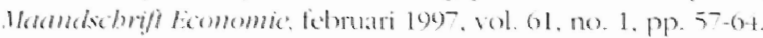


Bij de opleidingen die door opleidingstypen met een aanbodoverschot worden verdrongen, zal het aantal baanopeningen vanwege dit substitutieproces kleiner worden. Daarentegen zal er voor de opleidingen die verwant zijn aan de opleidingen met een tekortschietend aanbod juist sprake zijn van extra baanopeningen. Deze passiete substitutie-effecten zijn derhalve van belang voor de arbeidsmarktperspectieven van de desbetreffende opleidingen.

De vraag-aanbod-confrontatie geeft voor elk opleidingstype ook een indicatie van de toekomstige knelpunten in de personeelsvoorziening. Daarbij bepalen de uitbreidingsen vervangingsvraag samen de recruteringsbeboefte per opleidingstype. Bij krimpende werkgelegenheid voor een bepaald opleidingstype wordt deze recruteringsbehoefte op een andere wijze berekend dan het aantal baanopeningen voor nieuwkomers op de arbeidsmarkt. In dat geval bestaat immers vanuit het perspectief van bedrijven de mogelijkheid om de gedwongen uitstroom van het zittende personeel te verminderen. Zeker wanneer bedrijven geconfronteerd worden met een krappe arbeidsmarkt voor een bepaald opleidingstype, zullen zij van deze mogelijkheid gebruik maken. 


\section{De arbeidsmarkt in vogelvlucht}

In dit boofdstuk komen de geprognosticeerde arbeidsmarktontwikkelingen op een boog aggregatieniveau aan de orde. Eerst wordt een beeld geschetst van de ontwikkeling van de arbeidsmarkt op macro-niveau. Hierbij zal aandacht worden besteed aan de achterliggende economische en sociale factoren die een belangrijke invloed bebben op de ontwikkeling van vraag en aanbod op de arbeidsmarkt. Daarna worden de verwachte arbeidsmarktontwikkelingen verbijzonderd naar bedrijfssector; beroepssector en opleidingsniveau, waarbij de ontwikkeling van bedrijfssectoren en beroepssectoren alleen betrekking zal bebben op de ontwikkelingen aan de vraagzijde van de arbeidsmarkt. Bij de bespreking van de ontwikkelingen op macro-niveau en die op het niveau van bedriffsectoren en beroepssectoren zal steeds een vergelijking worden gemaakt met de ontwikkelingen in de afgelopen jaren. Overigens betreft met name de geschetste ontwikkeling naar beroepssector en opleidingsniveau nog steeds ontwikkelingen op een relatief hoog aggregatieniveau. Een verdere verbijzondering naar beroepsgroepen en opleidingstypen volgt in de latere boofdstukken.

\subsection{De verwachte arbeidsmarktontwikkeling}

De economische groei die Nederland de laatste jaren doormakt, zal volgens ramingen van het CPB ook in de nabije toekomst doorzetten. Naar verwachting zal het bruto binnenlands product (BBP) tussen 1997 en 2000 jaarlijks toenemen met 3\%. De samenstelling hiervan zal echter een verschuiving te zien geven van gezinsconsumptie naar uitvoer. De depreciatie van de gulden ten opzichte van de dollar zal een verbeterde concurrentiepositie tot gevolg hebben. In combinatie met de aantrekkende wereldeconomie zal dit leiden tot een stijging van het uitvoervolume. In 1997 zal deze stijging o.a. door de nadelige effecten van de varkenspest beperkt blijven tot $5,75 \%$, maar in de periode 1997-2000 zal de toename van de uitvoer gemiddeld 7,5\% per jatar bedragen.

De hierboven geschetste verwachtingen voor de Nederlandse economie op de midclellange termijn betreffen het zogenaamde gunstig scenario wit het Centraal Economisch Plan 1996. Deze verwachtingen resulteren in een stijging van de werkgelegenheidsgrexi van 1,4\% per jaar in de periode 1992-1996 naar 1,7\% per jaar in de periode 1997-2002 (zie tabel 1.1). Hierdoor zal de werkgelegenheid (de 'uitbreidingsvraag') tussen 1997 en 2002 stijgen met gemiddeld ca. 110.000 banen per jaar.

Uit de Enquête Beroepsbevolking van het CBS blijkt dat het aandeel van de ouderen (50-64 jarigen) in de werkzame beroepsbevolking van 1992 tot 1996 is toegenomen van $13.7 \%$ tot $15.3 \%$. Door deze vergrijzing zal in de toekomst het aantal werknemers dat wegens arbeidsongeschiktheid, pensionering en vervroegde wittreding de arbeidsmarkt verlaat, stijgen. Volgens de arbeidsmarktprognoses zal de uitstrom van $3,0 \%$ per jaar in de periode 1992-1996 toenemen tot 3,3\% per jaar in de periode 1997-2002. I it betekent dat voor de prognoseperiode het aantal hierdoor vrijkomende banen op jaarlasis 28.000 hoger geraamd wordt dan voor de voorgaande vif jaar. 
Tabel 1.1

Arbeidsmarktontwikkeling 1992-1996 en prognoses voor 1997-2002 (gemiddelde jaarlijkse percentages)

$\begin{array}{lrr} & 1992-1996 & \mathbf{1 9 9 7 - 2 0 0 2} \\ & \% & \% \\ \text { Werkgelegenheidstoename } & 1,4 & 1,7 \\ \text { Arbeidsmarktuitstroom } & 3,0 & 3,3 \\ \text { Baanopeningen } & 4,4 & 5,0 \\ \text { Instroom schoolverlaters } & 5,6 & 4,2\end{array}$

Bron: $\mathrm{CPB} / \mathrm{ROA}$

Niet in alle openvallende banen zal worden voorzien, omdat de uitstroom van werkenden ook benut kan worden om het personeelsbestand te laten krimpen. Wel wordt verwacht dat, evenals de arbeidsmarktuitstroom, ook de vervangingsvraag groter zal zijn dan in de afgelopen vijf jaar. Daarnaast zal een deel van de vrijkomende arbeidsplaatsen worden opgevuld door personen met een andere opleidingsachtergrond dan de vertrekkende werknemer, waardoor ook de uitbreidingsvraag naar deze laatstgenoemde opleidingstypen toeneemt.

De grotere werkgelegenheidstoename en arbeidsmarktuitstroom leiden tot een stijging van het aantal baanopeningen. In de periode 1997-2002 zal dit aantal stijgen met 5,0\% per jaar tegen een jaarlijkse stijging met $4,4 \%$ in de eerste helft van de jaren negentig.

Aan de aanbodzijde eist de ontgroening zijn tol. Het aantal jongeren tot 24 jaar daalt al enkele jaren. Hierdoor neemt het aantal onderwijsvolgenden af, waardoor uiteraard ook het aantal schoolverlaters afneemt. Daarnaast volgen jongeren steeds langer een voltijdopleiding, waardoor hun intrede op de arbeidsmarkt wordt uitgesteld. Zo volgde in 1975 slechts $3 \%$ van alle 24 -jarige mannen en $1 \%$ van alle vrouwen van 24 jaar voltijdonderwijs. In 1995 waren deze percentages gestegen tot respectievelijk 19 en 14\%. Het aantal schoolverlaters dat instroomt op de arbeidsmarkt zal als gevolg van deze ontwikkelingen dalen van $5,6 \%$ per jaar in de eerste helft van de jaren negentig tot $4,2 \%$ per jaar in de periode 1997-2002.

Dus enerzijds zal het aantal baanopeningen stijgen als gevolg van de economische groei in combinatie met de demografische ontwikkelingen. Anderzijds zal de instroom op de arbeidsmarkt dalen, watadoor schoolverlaters gewildere kandidaten worden voor werkgevers. Per saldo resulteert dit in gemiddeld gunstiger perspectieven voor nieuwkomers op de arbeidsmarkt dan in de afgelopen periode.

In tegenstelling tot het in de periode 1992-1996 op macro-niveau opgetreden arbeidsoverschot zal in de periode 1997-2002 op dit niveau een tekort aan arbeidskrachten ontstaan. Dit kan leiden tot grote knelpunten in de personeelswoorziening. Werkgevers kunnen op deze ontwikkeling inspelen door enerzijds de uitstroom van oudere werk-

I Zie CBS, Kuantaalschrift Onderwigstatistieken 199--1. Vorburg Heerlen. 199- 
nemers af te remmen en anderzijds door personeel aan te trekken afkomstig uit een aantal groepen met een zwakke arbeidsmarktpositie, zoals ongeschoolden en langdurig werklozen". Ook het verhogen van de participatiegraad zou een belangrijke rol kunnen spelen bij het voorkomen van de verwachte knelpunten in de personeelsvoorziening. Het spreekt voor zich dat dit noodzaakt tot aanzienlijke bij- en omscholingsinspanningen. Daarbij kunnen ook overheidsmaatregelen worden genomen om de grote uitstroom uit de beroepsbevolking tegen te gaan. Zo heeft de afgelopen jaren bijvoorbeeld de herkeuringsoperatie voor de WAO een positief effect gehad op het arbeidsaanbod. Het CPB verwacht dat ook de nieuwe bijstandswetgeving het arbeidsaanbod voor 1997 zal doen aantrekken.

\subsection{Werkgelegenheidsontwikkeling naar bedrijfssector}

Tabel 1.2 geeft aan dat de gunstige ontwikkeling van de werkgelegenheid naar verwachting zal optreden in vrijwel alle onderscheiden bedrijfssectoren. Alleen de sectoren landbouw en visserij en energie geven een afwijkend beeld te zien. Voor de energiesector is er echter in de periode 1997-2002 wel sprake van een duidelijke verbetering in vergelijking met de periode 1992-1996. Belangrijkste oorzaak hiervan is de groei van de energie-intensieve sectoren. De sector landbouw en visserij gaf in de afgelopen jaren ook reeds een daling van de werkgelegenheid te zien. Deze dalende ontwikkeling is dus structureel. Daarnaast hebben productiebeperkende overheidsmaatregelen in de zuivel en milieu-maatregelen een negatief effect .

De grootste toename van de werkgelegenheid wordt verwacht in de horeca, reparatic en zakelijke dienstverlening. Een belangrijke oorzaak hiervoor is het feit dat de uitzendbranche deel uitmaakt van deze sector. Naast uitbesteding van dienstenactiviteiten door bedrijven vormt met name de flexibilisering van de arbeidsmarkt een structurele factor achter de toenemende werkgelegenheid in deze sector. De ongunstige arbeidsmarktsituatie in de afgelopen jaren heeft de flexibilisering nog bevorderd. Desondanks wijzen de prognoses voor de periode 1997-2000 op een lagere werkgelegenheidsgroei in deze bedrijfssector in vergelijking met de voorafgatande periode. Dit houdt o.a. ver band met ontwikkelingen in andere sectoren. De aantrekkende afzet van goederen en diensten werd daar in eerste instantie opgevangen door het inhuren van uilzendkrach ten. Nu echter verwacht wordt dat de economische groei aanhoudt, gaan steeds meer bedrijven ertoe over deze uitzendkrachten in eigen dienst te nemen. Hierdoor treedt een verschuiving in de werkgelegenheid op van de sector horeca, reparatic en zakelijke dienstverlening naar met name de industriële sectoren. Deze ontwikkeling ten gevolge van de verder aantrekkende conjunctur biedt aldus enig tegenwicht an hee effect van de structurele toename van het flexibel werken.

De sector handel laat een enigszins sterkere groei van de werkgelegenheid zien in vergelijking met de periode 1992-1996. Deze hogere toename van de werkgetegenheid

2 Bij het bepalen van de arbeidsmarktperspectieven van schoolverlaters word veronderstedd dal werkzoekenden die langer dan een jatar zonder werk zijn. niet concurreren med schoolverlatem

3 Het betreft hier een sectorindeling op een hoger aggregatieniveau dan de indeling die in de Statistisc be Bijlage wordt gehanteerd.

+ Zie CPB. Centraal Economisch Plan 1997. Den Haag. 1997. 
houdt mogelijk mede verband met de verruiming van de openingstijden in de detailhandel. Onderdelen van de sector transport en communicatie (o.a. luchtvaart, openbaar vervoer en communicatie) zullen een sterkere marktwerking ondervinden als gevolg van deregulering en liberalisering. Enerzijds zal dit de prijzen doen dalen, waardoor de afzet toeneemt en daarmee ook de werkgelegenheid. Anderzijds zal echter de arbeidsproductiviteit stijgen, waardoor de werkgelegenheid afneemt. Per saldo lijken deze ontwikkelingen evenwel tot een stijging van de werkgelegenheid te leiden.

Tabel 1.2

Ontwikkeling aantal werkenden per bedrijfssector 1992-1996* en uitbreidingsvraag 1997-2002 (gemiddelde jaarlijkse percentages)

\begin{tabular}{|c|c|c|c|}
\hline Bedrijfssector & $\begin{array}{r}\text { Aantal werkenden } \\
\text { (gem. '95/96) }\end{array}$ & $\begin{array}{r}1992-1996 \\
\%\end{array}$ & $\begin{array}{r}1997-2002 \\
\%\end{array}$ \\
\hline Landbouw en visserij & 228.000 & $-0,8$ & $-1,0$ \\
\hline Voeding & 158.000 & $-1,1$ & 0,4 \\
\hline Chemie & 130.500 & $-1,7$ & 1,7 \\
\hline Metaal en elektrotechniek & 510.500 & $-0,7$ & 1,8 \\
\hline Overige industrie & 209.000 & $-5,1$ & 0,9 \\
\hline Energie & 61.500 & $-1,8$ & $-0,1$ \\
\hline Bouw en onroerend goed & 455.500 & 2,8 & 0,8 \\
\hline Handel & 865.000 & 1,9 & 2,2 \\
\hline Transport en communicatie & 385.500 & 1,0 & 1,5 \\
\hline Bank-en verzekeringswezen & 223.500 & 1,2 & 0,4 \\
\hline Horeca, reparatie en zakelijke dienstverlening & 889.000 & 5,6 & 3,6 \\
\hline Kwartaire diensten & 982.500 & 1,6 & 1,7 \\
\hline Overheid en onderwijs & 909.500 & 1,6 & 0,3 \\
\hline Totaal (incl. sector onbekend) & 6.115 .000 & 1,4 & 1,7 \\
\hline
\end{tabular}

* Het betreft hier een sectorindeling op een hoger aggregatieniveau dan de indeling die in de Sratistische Bijlage wordt gehanteerd.

Bron: $\mathrm{CBS} / \mathrm{CPB} / \mathrm{ROA}$

De door de Europese monetaire integratie bevorderde toename van de internationale concurrentie in de financiële dienstverlening zal leiden tot verdere organisatorische aanpassingen en technologische vernieuwingen in deze sector. Hierdoor zal in het bank- en verzekeringswezen de werkgelegenheidsgroei geringer zijn in vergelijking met de situatie in de eerste helft van de jaren negentig. Toen werden de nadelige werkgelegenheidseffecten van de in die periode doorgevoerde organisatorische en technologische veranderingen nog enigszins beperkt door invoering van de 36-urige werkweek, matar die mogelijkheid is inmiddels nagenoeg uitgeput ${ }^{5}$.

5 Zie CPB. Contral Ecomomisch Plan 1996, Den Ha:g. 1996. 


\subsection{Werkgelegenheidsontwikkeling naar beroepssector}

Behalve veranderingen van de werkgelegenheid in bedrijfssectoren, spelen ook verschuivingen in de beroepenstructuur binnen die sectoren een rol in de totstandkoming van de uitbreidingsvraag voor beroepen. Daarom worden in deze paragraaf de werkgelegenheidsprognoses voor de onderscheiden beroepssectoren besproken.

Nagenoeg alle beroepssectoren vertonen in de prognoseperiode een stijgende werkgelegenheid, zoals blijkt uit tabel 1.3. Alleen de agrarische beroepen vertonen een enigszins teruglopende werkgelegenheidsontwikkeling, hetgeen een weerspiegeling is van de verwachte werkgelegenheidsdaling in de bedrijfssector landbouw en visserij. Overigens lijkt er wel sprake te zijn van een licht herstel in vergelijking met de periode 1992-1995.

Tabel 1.3

Ontwikkeling aantal werkenden per beroepssector 1992-1995* en uitbreidingsvraag 1997-2002 (gemiddelde jaarlijkse percentages)

Beroepssector

Pedagogische beroepen

Culturele beroepen

Agrarische beroepen

Technische en industrieberoepen

Transportberoepen

Medische en paramedische beroepen

Economisch-administratieve beroepen

Informaticaberoepen

Sociaal-culturele beroepen

Verzorgende en dienstverlenende beroepen

Openbare orde en veiligheidsberoepen

Totaal (incl. beroep onbekend) aantal werkenden

(gem. '95/'96)

336.500

116.000

274.000

1.431 .500

353.500

337.000

1.659 .500

154.000

158.000

990.500

99.500

6.115 .000
1992-1995

\section{$\%$}

1997-2002

\section{$\%$}

0,8

$5,4 \quad 1,5$

$-1,4 \quad-0,1$

$-0,7 \quad 1,0$

$1,2 \quad 2,0$

$1,3 \quad 0,9$

$0,8-2,5$

$1,0 \quad 3,5$

$1,9 \quad 2,8$

$2,4 \quad 2,0$

$1,0 \quad 0,2$

1,2

17

* Doordat in 1996 de restcategorie 'beroep onbekend' tot een minimum kan worden teruggebracht, wordt hier cen verge lijking gemaakt met de ontwikkeling in de periode 1992-1995, omdat anders de werkgelegenheidsgroei in de verschillende beroepssectoren zou worden overschat.

Bron: CBS/ROA

Ook voor de andere beroepen treden er natr verwachting verschuivingen op ten opzichte van deze eerdere periode. Voor de transportheroepen, de economisch-administratieve beroepen, de sociaal-culturele beroepen en de informaticabereepen wordt een grotere uithreidingsvraag verwacht. Voor de technische en industrieterexpen wordt zelfs een omslag verwacht van een dalende werkgelegenheid natr cen stijging van de werkgelegenheid. Daar deze beroepen geconcentreerd zijn in de industriële bedrijfssectoren - waar de werkgelegenheidsontwikkeling zich sterk herstelt - is dit echter niet verrassend. 
Overigens geldt voor alle beroepssectoren dat zij qua samenstelling een zeer heterogeen karakter hebben. Binnen beroepssectoren kunnen daardoor, zoals in hoofdstuk 2 zal blijken, sterk uiteenlopende ontwikkelingen optreden en zowel groeiende als krimpende beroepen voorkomen.

\subsection{Werkgelegenheidsontwikkeling naar opleidingsniveau}

Over de periode 1997-2002 wordt een totale werkgelegenheidstoename van 8,8\% verwacht. Wanneer echter onderscheid gemaakt wordt naar de verschillende opleidingsniveaus, worden binnen de totale vraagontwikkeling duidelijk grote verschillen zichtbaar.

Tabel 1.4 geeft een overzicht van de verwachte uitbreidingsvraag voor de onderscheiden opleidingsniveaus. De voorspelde uitbreidingsvraag is gebaseerd op ontwikkelingen aan de vraagzijde van de arbeidsmarkt. Door aanpassingsreacties op discrepanties tussen vraag en aanbod kan de feitelijke ontwikkeling van het aantal werkenden met een bepaalde opleidingsachtergrond evenwel afwijken van de uitbreidingsvraag.

Tabel 1.4

Componenten van de werkgelegenheidsverschuivingen per opleidingsniveau (netto-effecten)* , 1997-2002**

\section{Opleidingsniveau}

Basisondenwijs

VBO, MAVO

MBO/LLW, HAVO/NWO

HBO

WO

Totaal

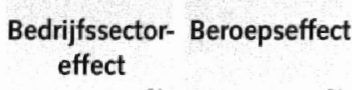

$\%$

9,3

9,1

9,0

8,2

9,0

8,8

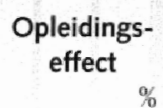

Totaal substitutie $\%$

$-24,5$
$-7,4$
4,7
7,0
7,3

0,0

$-17,6$

$-4,8$

13,8 17,1 24,6

8.8

* In legenstelling tot de tabellen 1.2 en 1.3 hebben de percentages in deze tabel betrekking op de gehele periode 1997-2002.

"W" Ilet totalniveau van het beroepseffect, opleidingseffect en substitutie-effect is steeds nul, ondat het hier gat on verschuivingen in de werkgelegenheidsaandelen. Een positief beroepseffect op het ene opleidingsniveau impliceert derhalve een negatief effect op een ander niveat.

Bron: ROA

Voor het basisonderwijs wordt een forse daling van de uitbreidingsvratag van rum $17{ }^{\circ}$ verwatht. Dit in tegenstelling tot de situatie op WO-niveau, die een stiiging met bijna $25^{\circ}$ te zien geeft. Er geld dat hoe hoger het opleidingsniveau, hoe groter de verwachte uithreidingsvratag is.

Op hasis van de groei van de verschillende bedriffssectoren watrin de werkenden met cen beparalde opleidingsachtergrond emplooi vinden. zou op alle opleidingsniveaus een groei van de vraig mogen worden verwacht. Dit bedrijfsectoreffect is het grootst vor het basisonderwijs diar mensen met uitsluitend basisonderwijs sterk vertegenwoordigd zijn in de sterkst groeiende bedriffsectoren horeca, reparatie en zakelijke dienstretening. handel, metaial en elektrotechniek en transport en communicatie. De verschillen in dit sectoreffect tussen de opleidingsniveaus zijn overigens zeer klein. 
Het beroepseffect, dat optreedt door het veranderen van de spreiding van de werkgelegenheid per bedrijfssector over beroepsklassen, is voor geen enkel opleidingsniveau erg groot. Het is negatief voor de laagste twee opleidingsniveaus en positief voor de overige. Lager opgeleiden hebben dus relatief veel te lijden van verschuivingen van de beroepenstructuur binnen de bedrijfssectoren. Universitair opgeleiden profiteren het sterkst van dit effect.

Verder blijkt dat er een verschuiving optreedt in het niveau van de gevraagde kwalificaties. Het opleidingseffect wordt immers kleiner naarmate het opleidingsniveau lager is. De opleidingseffecten wijzen in dezelfde richting als de beroepseffecten, maar zijn wel veel groter. Ongeschoolden ondervinden de meeste hinder van de verhoging van de kwalificatie-eisen die door werkgevers worden gesteld. Personen met een opleiding op WO-niveau en in iets mindere mate op HBO-niveau, hebben hiervan het meeste voordeel.

Bij verschillen tussen vraag en aanbod zullen zowel aanbieders als vragers van arbeid hun eisen aanpassen. Werkzoekenden die geconfronteerd worden met een gebrek aan baanopeningen binnen hun opleidingsgebied zullen eerder een functie accepteren op een lager niveau of in een afwijkende richting. Er is dan sprake van actieve substitutie. Ook zullen werkgevers mensen met een ander opleidingstype of opleidingsniveau gain aantrekken als ze problemen krijgen met het vervullen van openstaande banen. In dal geval heeft de substitutie een passief karakter.

Dit laatste substitutie-effect is naar verwachting negatief voor de opleidingsniveaus VBO, MAVO en MBO/leerlingwezen, HAVO/VWO. VBO- en MAVO-opgeleiden hebben onder meer te lijden van verdringing door mensen met uitsluitend een basisopleiding. Daarentegen worden degenen met een $\mathrm{MBO} /$ leerlingwezen- of $\mathrm{HAVO} / \mathrm{VWO}$-opleiding geconfronteerd met een neerwaartse verdringing door HBO'ers. Het WO-niveau profiteert het meest van het ontstaan van extra vraag als gevolg van het tekortschictend atnbod uit verwante opleidingsrichtingen.

\subsection{Arbeidsmarktperspectieven naar opleidingsniveau}

Door de verwachte baanopeningen te confronteren met de verwachte instrom van schoolverlaters kunnen de arbeidsmarktperspectieven worden aangegeven. Voor de verschillende opleidingsniveaus zijn in tabel 1.5 de zogeheten Indicator toekomstige

Tabel 1.5

Toekomstige arbeidsmarktperspectieven per opleidingsniveau, 1997-2002

\section{Opleidingsniveau}

Basisonderwijs

IBO, MAIO

MBOLLLW. HAVONWO

$\mathrm{HBO}$

WO

Bron: ROA

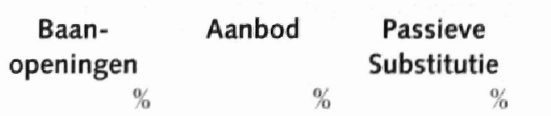

ITA

Typering

23,3

31,2

33,7

34,1

38.2
0,3

$-3,9$

$-0,7$

1,1

5.0
26,2

30,3

21,4

32,1
1,07

0.99

0,98

0.90

0,93 matig

goed

goed

goed

goed 
arbeidsmarktperspectieven (ITA) ${ }^{6}$ vermeld. Naarmate de ITA kleiner is, zijn er meer baanopeningen dan instromers en is het arbeidsmarktperspectief dus gunstiger. Met uitzondering van het basisonderwijs zijn de perspectieven op alle niveaus gemiddeld goed.

Eerdere prognoses voor de periode $1995-2000^{7}$ wezen al in de richting van gunstige vooruitzichten voor met name het hoger onderwijs. Op grond van de huidige prognoses mag worden verwacht dat deze ontwikkeling zich voortzet. Bovendien verbeteren ook duidelijk de arbeidsmarktperspectieven van het $\mathrm{MBO} /$ leerlingwezen en het HAVO/VWO

Overigens kunnen er binnen de verschillende opleidingsniveaus nog sterk uiteenlopende arbeidsmarktvooruitzichten bestaan. Met uitzondering van basisonderwijs komen op elk niveau zowel opleidingstypen met goede tot zeer goede perspectieven als opleidingstypen met matige of slechte arbeidsmarktperspectieven voor.

Tabel 1.6 laat zien dat het percentage schoolverlaters met een opleidingstype met een slecht of matig arbeidsmarktperspectief, afneemt naarmate het opleidingsniveau hoger is. Schoolverlaters met uitsluitend basisonderwijs hebben matige arbeidsmarktperspectieven, zoals al uit tabel 1.5 bleek.

Tabel 1.6

Percentage schoolverlaters met opleidingen waarvoor een slecht of matig arbeidsmarktperspectief wordt verwacht, per opleidingsniveau

Opleidingsniveau

Basisonderwijs

VBO, MAVO

MBO/LLW, HAVO/NWO

WO

Bron: $\mathrm{ROA}$

Hoewel op VBO- en MAVO-niveau gemiddeld een goed arbeidsmarktperspectief geldt, heeft ruim $20 \%$ van de schoolverlaters op dit niveau toch een opleidingstype gevolgd met slechte of matige vooruitzichten. Dit betreft met name de schoolverlaters van de opleidingstypen VBO installatietechniek, brood en banket, horeca en levensmiddelentechniek en administratie, handel en textiel. Daarentegen zijn de vooruitzichten voor schoolverlaters van MAVO, VBO landbouw en natuurlijke omgeving, vervoer, beveiliging en diverse technische opleidingstypen goed.

Gediplomeerden uit het MBO/leerlingwezen en HAVO/VWO hebben eveneens een gemidkleld goed arbeidsmarktvooruitzicht. Circa 13\% van de schoolverlaters op dit niveau zal worden geconfronteerd met matige of slechte vooruitzichten op de arbeids-

6) Zie voor een definitic de verklarende woordenlijst.

- Zie De arbeidsmarkt natar opleiding en beroep tot 2000. ROA-R-1995 3. Malastricht. 1995. 
markt. Vooral voor gediplomeerden van het opleidingstype MBO toerisme en recreatie zijn de vooruitzichten niet florissant. In mindere mate geldt dat voor de opleidingstypen MBO grafische techniek, bewegingstherapie, verzorging en opleidingstypen die opleiden tot dokters-, tandarts- en dierenartsassistent. Zeer gunstige perspectieven zijn er op dit niveau voor degenen met een opleiding operationele techniek, procestechniek, gezondheidstechniek, verpleging en horeca.

Op HBO-niveau heeft slechts 6,2\% van de schoolverlaters een opleidingstype gevolgd dat, gelet op het arbeidsmarktperspectief, minder gunstig is. Dit betreft degenen die $\mathrm{HBO}$ personeelswerk of $\mathrm{HBO}$ milieukunde en levensmiddelentechnologie studeren. De HBO-opleidingstypen die een zeer gunstig vooruitzicht bieden zijn zeer divers: radiologie, landbouw en veeteelt, informatica, vervoer en logistiek, lerarenopleiding economie en maatschappij, recht en bestuur en bouwkunde.

Van de universitair opgeleiden, tenslotte, hebben uitsluitend de kunstwetenschappers een matig perspectief op de arbeidsmarkt. Zij maken in de komende periode evenwel slechts $1,7 \%$ van de instroom op WO-niveau uit. Ook op dit niveau biedt bouwkunde zeer goede perspectieven op de arbeidsmarkt. Dit geldt eveneens voor de opleidingstypen civiele techniek, informatica en bestuurlijke informatiekunde, accountancy en belastingen, tandheelkunde en bedrijfskunde. 
$\bar{c}$ 


\section{Ontwikkelingen op de arbeidsmarkt 1997-2002}

In dit boofdstuk komen de meest opmerkelijke verwachte ontwikkelingen op de arbeidsmarkt in de periode 1997-2002, verbijzonderd naar beroep en opleiding, gedetailleerd aan de orde. Eerst zullen de ontwikkelingen aan de vraagzijde van de arbeidsmarkt in de paragrafen 2.1 en 2.2 nader worden belicht. In paragraaf 2.1 zal worden ingegaan op de beroepen en opleidingen met de boogste uitbreidingsuraag en de opleidingen en beroepen met de sterkste werkgelegenheidskrimp. Daarna worden in paragraaf 2.2 de beroepen en opleidingen met de boogste en laagste vervangingsvraag gepresenteerd. Vervolgens wordt in paragraaf 2.3 een beeld geschetst van de verwachte baanopeningen. Bij een toename van de werkgelegenheid vormt de som van vervangingsvraag en uitbreidingsvraag bet aantal baanopeningen voor nieuwkomers op de arbeidsmarkt. Als er sprake is van een negatieve uitbreidingsvraag zijn er daarentegen alleen baanopeningen als gevolg van vervangingsvraag. Tegenover de vraag naar nieuwe arbeidskrachten staat bet verwachte aanbod op de arbeidsmarkt. Een belangrijk deel van bet toekomstige aanbod op de arbeidsmarkt wordt gevormd door de arbeidsmarktinstroom van schoolverlaters verbijzonderd naar opleidingstype. Deze arbeidsmarktinstroom komt aan de orde in paragraaf 2.4. In paragraaf 2.5 zullen de opleidingstypen in beeld worden gebracht die het meest zullen profiteren van het tekortschietende arbeidsaanbod voor andere opleidingstypen. Ten slotte wordt in deze paragraaf een overzicht gegeven van de opleidingstypen die het meest te kampen zullen bebben met verdringing door andere opleidingstypen.

\subsection{Uitbreidingsvraag}

\section{Beroepen}

Zoals uit tabel 1.1 reeds naar voren kwam, wordt voor de periode 1997-2002 een gemiddelde jaarlijkse uitbreidingsvraag verwacht van 1,7\%. De verwachte werkgelegenheidsgroei ligt daarmee op een hoger niveau dan in de periode 1992-1996. Door de uiteenlopende werkgelegenheidsontwikkelingen in de diverse bedriffstakken en de verschuivingen in de beroepenstructuur van de werkgelegenheid binnen de bedrijfstakken, zijn er tussen de 123 onderscheiden beroepsgroepen echter grote verschillen in de uitbreidingsvraag

Tabel 2.1 geeft een overzicht van de beroepen met de hoogste uitbreidingsvraag. Alle beroepen op deze ranglijst van de sterkst groeiende beroepen behoren tot de middelbare, hogere of wetenschappelijke beroepen. De uitbreidingsvraag is het hoogst voor de beroepsgroep stewards. Ook in de periode 1992-1996 groeide de werkgelegenheid in deze beroepsgroep, die ook de grondstewards omvat, vrij sterk. De erg hoge uitbreidingsvraag voor deze beroepsgroep is voor een belangrijk deel toe te schrijven an de explosieve groei van het vliegverkeer.

Ook bij de productieplanners is de uitbreidingsvraag erg hoog: ruim $8 \%$ per jaar, al is er daarbij sprake van een afremming van de groei, vergeleken met de werkgelegenheidstoename voor deze beroepsgroep in de afgelopen jaren. Naar verwachting zal de groci 
van deze beroepsgroep zich vooral voordoen in de metaalindustrie en de bedrijfssector overige industrie. Voor de beroepsgroepen organisatie-adviseurs en organisatiedeskundigen is de toekomstige uitbreidingsvraag naar verwachting eveneens erg hoog (respectievelijk 7,7 en 6,1\%). Een aanzienlijk deel van de groei van deze beroepen vindt plaats in de commerciële en niet-commerciële dienstverlening. De werkgelegenheid in deze beroepen steeg ook al sterk in de periode 1992-1996. Bij de beroepsgroep sociaalwetenschappelijk medewerkers zal de daling van de werkgelegenheid in de jaren 19921996 daarentegen de komende jaren naar verwachting omslaan in een aanzienlijke werkgelegenheidsstijging. Ook voor de sociaal-wetenschappelijk onderzoekers is de verwachte uitbreidingsvraag erg hoog, hetgeen een voortzetting betekent van de trend van de afgelopen jaren. Ook hier vindt een aanzienlijk deel van deze groei plaats in de commerciële en niet-commerciële dienstverlening.

Tabel 2.1

Beroepsgroepen met relatief gezien de hoogste uitbreidingsvraag 1997-2002 (totaal aantal en gemiddeld jaarlijks percentage) en 1992-1996 (gemiddeld jaarlijks percentage).

Beroepsgroep
Stewards
Productieplanners
Organisatie-adviseurs
Sociaal-wetenschappelijk medewerkers
Organisatiedeskundigen
Accountants
Milieuhygiënisten en agrarisch
vertegenwoordigers
Onderwijskundig medewerkers
Ziekenverzorgenden
Materiaalkundigen
Grafisch ontwerpers
Sociaal-wetenschappelijk onderzoekers

Bron: ROA

\begin{tabular}{rrrrl}
\multicolumn{3}{c}{$\begin{array}{c}\text { Prognose } \\
\text { aantal }\end{array}$} & 1997-2002 & \multicolumn{2}{c}{ 1992-1996 } \\
& $\%$ & typering & $\%$ & typering \\
6.700 & 10,0 & erg hoog & 9,3 & erg hoog \\
25.900 & 8,1 & erg hoog & 15,8 & erg hoog \\
15.300 & 7,7 & erg hoog & 7,2 & erg hoog \\
2.700 & 6,4 & erg hoog & $-4,9$ & erg laag \\
6.800 & 6,1 & erg hoog & 6,2 & erg hoog \\
10.100 & 6,1 & erg hoog & 15,4 & erg hoog \\
& & & & \\
5.200 & 5,9 & erg hoog & 3,7 & hoog \\
2.800 & 5,5 & erg hoog & 1,8 & gemiddeld \\
18.200 & 5,4 & erg hoog & 6,4 & erg hoog \\
4.000 & 4,9 & erg hoog & 0,9 & gemiddeld \\
2.700 & 4,8 & erg hoog & 3,0 & hoog \\
5.600 & 4,7 & erg hoog & 5,5 & erg hoog
\end{tabular}

Tabel 2.2 geeft een overzicht van de beroepsgroepen die de komende periode het sterkst zullen krimpen. Het is opmerkelijk dat, zoals de tabel laat zien, ook de sterkst krimpende beroepsgroepen zonder uitzondering tot de wetenschappelijke, hogere en middelbare beroepsgroepen behoren. Maar liefst vijf beroepsgroepen hebben betrekking op docentfuncties in met name het voortgezet onderwijs. Vooral bij de docenten in de exacte, medische en verzorgende vakken en de docenten in de sociale vakken betekent dit een omslag in de werkgelegenheidsontwikkeling. Mogelijke verklaringen voor de negatieve uitbreidingsvraag naar deze docentfuncties zijn de 'ontgroening'van de bevolking, ombuigingen in het onderwijs en veranderde keuzevoorkeuren van leerlingen. De meeste krimp wordt overigens verwacht voor de beroepsgroep schippers en conductems. In deze beroepsgroep deed zich ook in de jaren 1992-1996 een sterke werkgelegenheidskrimp voor. Bezuinigingsmaatregelen bij de Nederlandse spoorwegen en het feit dat de scheepvaart al enkele jaren met overcapaciteit kampt kunnen hier een verklaring voor zijn. 
De twee agrarische beroepen met een negatieve uitbreidingsvraag - agrarische vakkrachten en agrarische bedrijfshoofden - illustreren de voortgaande inkrimping van de werkgelegenheid in de landbouwsector en de afname van het aantal zelfstandige bedrijven. Ten slotte is ook de verwachte werkgelegenheidskrimp voor bibliotheekassistenten opmerkelijk te noemen, gezien de erg hoge uitbreidingsvraag in de afgelopen periode.

Tabel 2.2

Beroepsgroepen met relatief gezien de laagste uitbreidingsvraag 1997-2002 (totaal aantal en gemiddeld jaarlijks percentage) en 1992-1996 (gemiddeld jaarlijks percentage)

\section{Beroepsgroep}

Schippers en conducteurs

Docenten sociale vakken (le graads)

Docenten exacte, medische en

verzorgende vakken (2e graads)

Agrarische vakkrachten

Politieagenten, onderofficieren en

beveiligingsemployés

Docenten sociale vakken (2e graads)

Docenten talen en expressie

Docenten economisch-administratieve

vakken (2e graads)

Receptionisten en administratieve employés

Agrarische bedrijfshoofden

Bibliotheekassistenten

Administratieve transportemployés

\section{Prognose 1997-2002}

aantal $\%$ typering

$-3.600 \quad-5,2 \quad$ erg laag

$\begin{array}{lll}-700 & -2,4 & \text { erg laag }\end{array}$

$-1.500 \quad-1,7 \quad$ erg laag

$\begin{array}{lll}-800 & -1,7 & \text { erg laag }\end{array}$

$-2.900 \quad-1,3 \quad$ erg laag

$-700-1,2 \quad$ erg laag

$-1.800 \quad-1,0 \quad$ erg laag

$-400 \quad-0,9 \quad$ erg laag

$-9.100 \quad-0,8 \quad$ erg laag

$-4.500 \quad-0,7$

$-500 \quad-0,6$

$-900 \quad-0,6$
1992-1996

$\% \quad$ typering

$-6,1 \quad$ erg laag

$-0,4 \quad$ laag

3,4 hoog

$-6,0$ erg laag

0,1 laag

4,1 hoog

$2,3 \quad h o o g$

1,8 gemiddeld

$-3,1$ erg laag

$-1,1$ erg laag

6,9 erg hoog

$-0,3$ lang

Bron: ROA

\section{Opleidingen}

De tussen bedrijfssectoren uiteenlopende werkgelegenheidsontwikkeling en de verschuivingen in de beroepenstructuur binnen bedrijfssectoren bepalen in belangrijke mate de vraag naar arbeidskrachten met een bepaalde opleidingsachtergrond. Maar ook binnen beroepen kunnen er verschuivingen in de gevraagde kwalificaties optreden die een grote invloed hebben op de uitbreidingsvraag voor bepaalde opleidingstypen.

Tabel 2.3 geeft een overzicht van de opleidingstypen waarvoor de komende jaren relatief gezien de grootste uitbreidingsvraag wordt verwacht. Voor al de\%e opleidingstypen wordt een uitbreidingsvraag van $5 \%$ of meer per jaar verwacht. Bijna alle opleidingstypen hebben betrekking op hoger opgeleiden. De grootste vraag zal zich voordoen bij het opleidingstype WO informatica en bestuurlijke informatickunde. De informatiseringstendens veroorzaakte vooral aan het eind van de periode 1992-1996 ook al een erg hoge vraag naar mensen met deze opleidingsachtergrond. Wat dat betreft kan zelfs gesproken worden van een afnemende groei, hoewel de jaarlijkse uitbreidingsvraag ook de komende jaren nog op het erg hoge niveau van bijna $10 \%$ zal liggen. I e $\%$ hoge uitbreidingsvraag is voor een belangrijk deel het gevolg van de toenemende vratg in de informaticaberoepen naar mensen met een informatica-opleiding op universitair niveau en de geringe omvang van die groep nu. Overigens wordt voor de informatica-oplei- 
ding op HBO-niveau ook een hoge uitbreidingsvraag verwacht. Daarnaast is het opvallend dat er maar liefst vier hogere economisch getinte opleidingstypen - WO bedriffskunde, WO econom(etr)ie, WO accountancy en belastingen en $\mathrm{HBO}$ commerciële economie - in deze ranglijst van de sterkst groeiende opleidingstypen voorkomen. Met name bij de WO-opleidingen is de (erg) hoge uitbreidingsvraag voor een belangrijk deel het gevolg van een verschuiving in de opleidingseisen in de beroepsgroepen waar degenen met deze opleidingsachtergrond emplooi vinden. Overigens is er ook bij deze hogere economische opleidingen sprake van een daling van de uitbreidingsvraag ten opzichte van de situatie in de afgelopen jaren. Voor het opleidingstype HBO landbouw en veeteelt wordt, gezien de ontwikkelingen in de landbouwsector, opmerkelijk genoeg een erg hoge uitbreidingsvraag verwacht. Dit contrasteert op het eerste gezicht ook met de in tabel 2.2 gepresenteerde lage uitbreidingsvraag bij de agrarische vakkrachten en bedriffshoofden. Weinig werkenden met de opleidingsachtergrond HBO landbouw en veeteelt zijn echter in deze beroepen werkzaam: het grootste gedeelte van de werkenden in deze beroepen heeft namelijk een MBO-opleiding. Het opleidingstype VBO beveiliging is de enige lagere opleiding in deze ranglijst van opleidingen die sterk groeien. De erg hoge uitbreidingsvraag voor dit opleidingstype is voor het overgrote deel het gevolg van een upgrading van de opleidingseisen in de bewakingsfuncties. Ook bij dit opleidingstype is er echter sprake van een afnemende uitbreidingsvraag in vergelijking met de afgelopen jaren. Het opleidingstype op middelbaar niveau in deze tabel is de opleiding $M B O / L L W$ apothekersassistent. Bij dit opleidingstype is er sprake van een voortzetting van de werkgelegenheidsgroei van de afgelopen jaren. Daarentegen is er voor het opleidingstype WO bouwkunde sprake van een opmerkelijke omslag in de uitbreidingsvraag. De afgelopen jaren daalde de vraag met gemiddeld $5 \%$ per jaar, terwijl er voor de komende jaren een jaarlijkse uitbreidingsvraag van 5\% wordt verwacht. Deze groei is voor een groot deel toe te schrijven aan de toenemende werkgelegenheid in de beroepsgroep weg-en waterbouwkundigen.

Tabel 2.3

Opleidingstypen met relatief gezien de hoogste uitbreidingsvraag 1997-2002 (totaal aantal en gemiddeld jaarlijks percentage) en 1992-1996 (gemiddeld jaarlijks percentage)

Opleidingstype

Wo informatica en besturlijke informatiekunde Wo bedriffskunde

WO econom(etr)ie

WO accountancy en belastingen

HBO landbouw en veeteelt

$\mathrm{VBO}$ beveiliging

HBO communicatie en jourmalistiek

WO botnkinde

IIBO recht en bestuur

HBO commerciële econonie

MBO/LLW apothekersassistent

$\mathrm{HBO}$ informatica
Prognose 1997-2002

\begin{tabular}{l|ll} 
aantal & $\%$ & typering
\end{tabular}

$\begin{array}{rll}4.700 & 9,8 & \text { erg hoog } \\ 10.300 & 8,3 & \text { erg hoog } \\ 15.900 & 6,6 & \text { erg hoog } \\ 6.700 & 6,4 & \text { erg hoog } \\ 2.900 & 6,1 & \text { erg hoog } \\ 4.000 & 6,1 & \text { erg hoog } \\ 5.300 & 5,8 & \text { erg hoog } \\ 3.000 & 5,7 & \text { erg hoog } \\ 6.900 & 5,6 & \text { hoog } \\ 12.000 & 5,2 & \text { hoog } \\ 4.800 & 5,1 & \text { hoog } \\ 10.200 & 5,0 & \text { hoog }\end{array}$

1992-1996

$\%$ typering

19,6 erg hoog

16,9 erg hoog

9,3 erg hoog

11,5 erg hoog

11,9 erg hoog

12,9 erg hoog

15,1 erg hoog

$-5,4$ erg laag

6.5 erg hoog

7.7 erg hoog

4,9 hoog

6,4 erg hoog

Bron: ROA 
Zoals blijkt uit tabel 2.4 zijn de lagere opleidingstypen oververtegenwoordigd bij de opleidingstypen met de sterkst teruglopende vraag. Overigens is dit een opmerkelijk verschil met de ranglijst van de sterkst krimpende beroepsgroepen. Bij alle lagere opleidingstypen is de krimpende werkgelegenheid geheel of vrijwel geheel het gevolg van een upgrading van de kwalificatie-eisen in de beroepen waarin degenen met de desbetreffende opleidingsachtergrond traditioneel emplooi vinden. Deze upgrading komt ook tot uiting in de veel sterkere dalingen van de vraag in deze tabel dan bij de sterkst krimpende beroepsgroepen in tabel 2.2. Naar verwachting zal de vraag voor het opleidingstype VBO grafische techniek het sterkste terug lopen, al ligt deze daling van de vraag op een veel lager niveau dan in de afgelopen jaren. Absoluut gezien is de afname van de vraag met ruim 80.000 werkenden in vijf jaar tijd het grootst voor de ongeschoolde arbeidskrachten met alleen basisonderwijs. Deze afname is louter het gevolg van de toenemende opleidingseisen in de beroepen waarin ongeschoolden werkzaam zijn. Op $\mathrm{MBO} /$ leerlingwezen-niveau wordt een dalende vraag verwacht voor de opleidingstypen $M B O$ verzekeringswezen en $M B O / L L W$ viegtuigtechniek. Met name bij de opleiding vliegtuigtechniek is de vraagafname echter veel geringer dan in de afgelopen jaren vanwege het Fokker-faillissement het geval was. De opleidingstypen WO theologie en HBO lerarenopleiding talen zijn de enige twee hogere opleidingen die op deze lijst van opleidingen waarvoor de vraag daalt voorkomen. Bij beide opleidingstypen is de verwachte vraagafname een voortzetting van de teruglopende vraag in de afgelopen periode, al is er bij WO theologie sprake van een aanzienlijke reductie van de vraagafname.

Tabel 2.4

Opleidingstypen met relatief gezien de laagste uitbreidingsvraag 1997-2002 (totaal aantal en gemiddeld jaarlijks percentage) en 1992-1996 (gemiddeld jaarlijks percentage)

Opleidingstype

VBO grafische techniek

Basisonderwijs

VBO landbouw en natuurlijke ongeving

WO theologie

VBO brood en banket

VBO administratie, handel en textiel

VBO motorvertuigentechniek

HBO lerarenopleiding talen

VBO mechanische techniek

MBO/LIW vliegtuigtechniek

VBO vervoer

VBO fijnmechanische techniek

Bron: ROA

\begin{tabular}{rrlrl}
\multicolumn{3}{c}{ Prognose 1997-2002 } & \multicolumn{2}{c}{$\mathbf{1 9 9 2 - 1 9 9 6}$} \\
aantal & $\%$ & typering & $\%$ & typering \\
& & & & \\
-1.000 & $-3,8$ & erg laag & $-12,9$ & erg laag \\
-80.400 & $-3,6$ & erg laag & $-3,1$ & erg laag \\
-12.700 & $-3,6$ & erg laag & $-4,7$ & erg laag \\
-900 & $-3,2$ & erg laag & $-10,7$ & erg laag \\
-1.700 & $-2,7$ & erg laag & $-8,9$ & erg laag \\
-15.300 & $-2,7$ & erg laag & $-3,3$ & erg laag \\
-4.700 & $-2,4$ & erg laag & $-6,1$ & erg laag \\
-3.200 & $-2,2$ & erg laag & $-2,8$ & erg laag \\
-11.100 & $-2,0$ & laag & $-3,9$ & erg laag \\
-600 & $-2,0$ & laag & $-10,3$ & erg laag \\
-3.000 & $-1,7$ & laag & $-4,6$ & erg laag \\
-400 & $-1,6$ & laag & $-14,7$ & erg laag
\end{tabular}

\subsection{Vervangingsvraag}

\section{Beroepen}

Vervangingsvraag is de vraag naar nieuwe arbeidskrachten die ontstaat doordat arbeidsplaatsen van werkenden die met pensioen gaan, arbeidsongeschikt worden of zich 
terug trekken van de arbeidsmarkt, vrijkomen. In deze paragraaf gaat het om de vervangingsvraag naar beroep. Ondanks de verwachte toename van de uitbreidingsvraag, is het grootste deel van de baanopeningen de komende jaren in het algemeen toch toe te schrijven aan de vervangingsvraag. Van de in tabel 1.1 gepresenteerde geaggregeerde arbeidsmarktuitstroom van jaarlijks 3,3\% wordt echter niet iedereen vervangen. Soms is er immers sprake van een krimpende werkgelegenheid zodat het vertrek van werkenden wordt gebruikt om de totale werkgelegenheid in een beroepsgroep terug te brengen. Bij de beroepen is er naast de vervangingsbehoefte vanwege de arbeidsmarktuittrede van werkenden bovendien sprake van een vervangingsvraag vanwege de arbeidsmobiliteit naar andere beroepsgroepen.

De gemiddelde vervangingsvraag per beroepsgroep zal in de periode 1997-2002 jaarlijks 3,5 procent bedragen. Dit is een toename ten opzichte van de periode 1992-1996, toen de gemiddelde jaarlijkse vervangingsbehoefte per beroepsklasse nog 3,2\% bedroeg. Tabel 2.5 geeft een beeld van de beroepsgroepen waarvoor de komende jaren de hoogste vervangingsvraag wordt verwacht. Opmerkelijk is dat de lijst gedomineerd wordt door een vijftal docentenberoepen. Bij de beroepsklasse docenten landbouw en techniek (2e graads) zal jaarlijks $6 \%$ van de docenten vervangen moeten worden door nieuwkomers. Over de gehele prognoseperiode betekent dit een vervangingsbehoefte van maar liefst ruim 35\%. Evenals bij de andere docentenberoepen wordt de hoge vervangingsvraag met name veroorzaakt door de vergrijzing van de werkenden in deze functies en cle als gevolg daarvan hoge arbeidsmarktuittrede van oudere leerkrachten. In absolute zin is de vervangingsvraag vooral erg hoog bij de docenten talen en expressie. Bij deze beroepsgroep zullen in vijf jaar tijd ruim 10.000 leerkrachten moeten worden vervangen door nieuwkomers. Uit de hoge vervangingsvraag voor de docentenberoepen blijkt ook dat de werkgelegenheidskrimp die voor enkele van deze beroepsgroepen wordt verwacht zeker niet mag worden geïnterpreteerd als een verslappende arbeidsmarkt voor leerkrachten in het voortgezet onderwijs, ondat de verwachte werkgelegenheidskrimp slechts een fractie is van de vervangingsbehoefte. In het kader op bladzijde 25 wordt hier verder op ingegalan.

Relattief gezien wordt voor de beroepsgroep café-en snackbarbouders de hoogste vervangingvraag verwacht. In deze beroepsgroep worden in de periode 1997-2002 4.500 mensen vervangen, dat is jaarlijks 6,6\% van het totaal aantal werkenden in deze beroepsgroep. Ook hier is de hoge vervangingsbehoefte vooral toe te schrijven aan de hoge uitstroom van oudere arbeidskrachten. Bij twee van de in tabel 2.5 genoemde beroepsgroepen is de erg hoge vervangingsbehoefte vooral het gevolg van de beroepsmobiliteit van met name jongere arbeidskrachten. Dit effect is het grootst bij de vervangingsvratag voor terpleeghulpen en leerling-verpleegkundigen. Leerling-verpleegkundigen zullen immers na het voltooien van de opleiding per definitie uitstromen naar de beroepsgroep verpleegkundigen. De vervangingsbehoefte bedraagt voor deze beroepsgroep de komende vijf jatr ruim 8.000 mensen. Ook de hoge vervangingsvraag bij de vakkenullem is te verklaren door het aparte karakter van het beroep. Deze beroepsgroep bestat voor een groot gedeelte uit scholieren en studenten, die het beroep in deeltijd als bijbaan witoefenen. Dit betekent in de praktijk dat men na het voltooien van de studie doorstroomt natar andere beroepen, waardoor de vervangingsbehoefte hoog wordt. Een andere beroepsgroep met een hoge vervangingvraag is de beroepsgroep comciërges. Hier is de vervangingsvatag weer vooral het gevolg van de 
vergrijzing van het personeelsbestand in deze functies en de als gevolg daarvan hoge uitstroom vanwege van pensionering, VUT en arbeidsongeschiktheid.

Tabel 2.5

Beroepsgroepen met relatief gezien de hoogste vervangingsvraag 1997-2002 (totaal aantal en gemiddeld jaarlijks percentage) en 1992-1996 (gemiddeld jaarlijks percentage)

Beroepsgroep

Café- en snackbarhouders

Docenten landbouw en techniek (2e graads)

Verpleeghulpen en leerling-verpleegkundigen

Conciërges

Vakkenvullers

Docenten economisch-administratieve vakken

(2e graads)

Docenten talen en expressie

Juridisch, bestuurlijk medewerkers

Elektrotechnisch ontwerpers en

bedrijfshoofden

Afdelingshoofden zorginstelling

Docenten sociale vakken (le graads)

Docenten exacte, medische en verzorgende

vakken (le graads)

\section{Prognose 1997-2002 \\ aantal \% typering}

$\begin{array}{lllll}4.500 & 6,6 & \text { erg hoog } & 6,3 & \text { erg hoog } \\ 6.200 & 6,2 & \text { erg hoog } & 4,5 & \text { hoog } \\ 8.200 & 6,2 & \text { erg hoog } & 5,8 & \text { erg hoog } \\ 9.300 & 6,0 & \text { erg hoog } & 5,9 & \text { erg hoog } \\ 7.300 & 5,9 & \text { erg hoog } & 9,3 & \text { erg hoog }\end{array}$

$2.400 \quad 5,2 \quad$ erg hoog

$10.200 \quad 5,2 \quad$ erg hoog

$4.900 \quad 5,1 \quad$ erg hoog

$2.800 \quad 4,9 \quad$ erg hoog

$2.700 \quad 4,9 \quad$ erg hoog

$1.600 \quad 4,8 \quad$ erg hoog

$4.700 \quad 4,8 \quad \operatorname{hoog}$
1992-1996

$\%$ typering

4,0 hoog

3,0 gemiddeld

4,6 hoog

4,1 hoog

$4,5 \operatorname{hoog}$

2,6 laag

3,4 gemiddeld

Bron: ROA

In de beroepsgroep juridisch, bestuurlijk medewerkers speelt de vervangingsvraag als gevolg van uitstroom van ouderen daarentegen slechts een beperkte rol. In deze beroepsgroep is het vooral de beroepsmobiliteit die ervoor zorgt dat er een vrij hoge vervangingsbehoefte van ruim $5 \%$ per jaar. Ten slotte is de vervangingsvraag voor de beroepsgroepen elektrotechnisch ontwerpers en bedriffshoofden en afdelingshoofden

Tabel 2.6

Beroepsgroepen met relatief gezien de laagste vervangingsvraag 1997-2002 (totaal aantal en gemiddeld jaarlijks percentage) en 1992-1996 (gemiddeld jaarlijks percentage)

Beroepsgroep

Programmeurs

Grafisch ontwerpers

Informatici

Activiteitenbegeleiders en

medewerkers arbeidsbemiddeling

Laders en lossers

Stewards

Agrarische vakkrachten

Economen

Verzorgend personeel

Commercieel emplovés

Svsteemanalisten

Technisch commercieel emplovés

\section{Prognose 1997-2002}

aantal $\%$ typering

$4.800 \quad 1,7 \quad$ erg laag

$1.100 \quad 2,0 \quad$ erg laag

$1.600 \quad 2,0 \quad$ erg laag

$6.000 \quad 2,1 \quad$ erg laag

$11.000 \quad 2,1 \quad$ erg laag

$1.200 \quad 2,1 \quad$ erg laag

$1.100 \quad 2,2 \quad$ erg laag

$1.700 \quad 2,3 \quad$ erg laag

$24.100 \quad 2,3 \quad$ erg laag

34.900

11.000

2.500
2,4 laag

2,4 laag

2,4 laag
1992-1996

$\% \quad$ typering

1,4 erg laag

3,0 gemiddeld

2,9 laag

2,3 erg laag

2,5 laag

0,6 erg laag

2,1 erg laag

2.3 erg laag

1,8 erg laag

1,8 erg laag

2,0 erg laag

2,0 erg laas

Bron: ROA 
zorginstelling erg hoog. Bij de laatstgenoemde beroepsgroep is de vervangingsbehoefte vooral het gevolg van de hoge arbeidsmarktuitstroom van de oudere vrouwen, die in deze functies werkzaam zijn.

In tabel 2.6 worden de beroepsgroepen met de laagste relatieve vervangingsvraag weergegeven. Het gaat hier vooral om beroepsgroepen waarin de werkgelegenheid de afgelopen jaren sterk is gestegen waardoor de werkenden in deze beroepen relatief jong zijn. Zo is er weinig vervangingsvraag naar programmeurs en informatici. In deze beroepen is respectievelijk 65 en $74 \%$ van de werkenden 40 jaar of jonger, waardoor de arbeidsmarktuittrede van werkenden vrijwel nihil is. Hetzelfde geldt voor de beroepsklasse met de op één na laagste vervangingsvraag: ruim $70 \%$ van de grafisch ontwerpers is niet ouder dan 40 jaar.

\section{Opleidingen}

In de prognoses voor de komende jaren is er in vergelijking met de eerder door het ROA opgestelde prognoses in de vervangingsvraag naar opleidingstype een extra component bij gekomen. Naast de uitstroom, die als gevolg van VUT, arbeidsongeschiktheid en pensioen ontstaat, wordt ook de doorstroom van werkenden van het ene naar het andere opleidingstype als een bron van vervangingsvraag beschouwd. Voorheen werden deze veranderingen in de opleidingsachtergrond in de aanbodciffers verrekend. Het meetellen van deze doorstroom bij de vervangingsvraag heeft vooral grote invloed op de vervangingsvraag van de lagere opleidingstypen, omdat laag opgeleide werkenden vaker een additionele opleiding volgen (bijvoorbeeld in het leerlingwezen) dan hooggeschoolden. In tabel 2.7 worden de opleidingstypen met de hoogste jaarlijkse vervangingsvraag gepresenteerd. Het valt op dat zes van de gepresenteerde opleidingstypen technische opleidingen zijn. Drie daarvan zijn VBO-opleidingen: VBO grafische techniek, VBO installatietechniek en VBO mechanische techniek. Dit zijn opleidingstypen waarvoor de vervangingsbehoefte ook de afgelopen jaren reeds erg hoog was. Bij VBO mechanische techniek is de erg hoge vervangingsvraag vooral toe te schrijven aan de hoge arbeidsmarktuitstroom van de relatief grote groep ouderen met deze opleidingsachtergrond. Bij de beide andere opleidingen is de erg hoge vervangingsvraag vooral toe te schrijven aan het vrijkomen van arbeids(leer)plaatsen, omdat veel jongeren met deze opleidingsgrond via het leerlingwezen doorstromen naar het $\mathrm{MBO}$ /eerlingwezen-niveau. In het kader op bladzijde 19 wordt hier nader op ingegaan. Ook bij het MAVO en de opleidingstypen VBO verzorging en VBO boreca en levensmiddelentechniek is de erg hoge vervangingsbehoefte vooral het gevolg van de doorstroom van werkenden via leerlingwezen of andere opleidingstrajecten naar een 'startkwalificatie' op $\mathrm{MBO} /$ leerlingwezen-niveau. 


\section{Uitgelicht: Doorstroom in VBO-techniek}

Het blijkt dat de arbeidsmarktperspectieven van de verschillende opleidingstypen binnen VBO-techniek in opeenvolgende edities van De arbeidsmarkt naar opleiding en beroep verbeteren. In de prognoses voor 1993-1998 werd voor de nieuwkomers op de arbeidsmarkt met de opleidingsachtergrond VBO-techniek een 'matig' perspectief voorspeld. Voor de periode 1995-2000 kreeg slechts 1 van de 9 onderscheiden opleidingstypen uit VBO-techniek het predikaat 'goed'. Voor de komende prognoseperiode 1997-2002 wordt voor maar liefst 5 van de 10 onderscheiden opleidingstypen binnen VBO-techniek voor de komende 5 jaar een goed arbeidsmarktperspectief verwacht (zie Statistische Bijlage, tabel 3.27). Slechts twee van deze opleidingstypen hebben slechte perspectieven.

Zo op het eerste gezicht zou men geneigd kunnen zijn de verbetering van de arbeidsmarktpositie van VBO-opleidingstypen uit het cluster techniek toe te schrijven aan de sterkere groei van de Nederlandse economie in de komende jaren. Het blijkt echter dat lager technisch opgeleiden nauwelijks van de te verwachten werkgelegenheidsgroei profiteren: de uitbreidingsvraag voor het tiental onderscheiden technische VBO-opleidingen is 'laag' of 'erg laag', vooral als gevolg van de toenemende opleidingseisen binnen de beroepsgroepen waarin degenen met een VBO-techniek opleiding werkzaam zijn. Voor 8 van de 10 opleidingstypen is zelfs sprake van een vraagafname. Alleen de opleidingstypen VBO bouwtechniek en VBO elektrotechniek zullen gedurende de prognoseperiode bescheiden groeien.

De onderliggende reden voor de verbeterde perspectieven van technische VBOopleidingen moet dus niet gezocht worden in de uitbreidingsvraag. Het blijkt dat vooral de doorstroom van VBO'ers in de technische richtingen naar MBO en leerlingwezen opleidingen in vergelijking met een aantal jaren geleden toeneemt. Dat heeft tot gevolg dat het aanbod op de arbeidsmarkt van lager opgeleide VBO'ers in technische richtingen afneemt. Daarnaast is de vervangingsvraag voor lager opgeleiden in technische richtingen vaak hoger doordat veel reeds werkzame personen met een dergelijke onderwijsachtergrond via leerlingwezen of andere opleidingstrajecten een middelbaar opleidingsniveau verwerven en daarmee arbeids(leer)plaatsen achterlaten. Zowel de lagere instroom als de relatief hoge vervangingsvraag zorgen voor een beter perspectief van opleidingstypen binnen VBO-techniek.

Ook de erg hoge vervangingsbehoefte bij $M B O / L L W$ laboratorium is vooral toe te schrijven aan de doorstroom van werkenden naar andere opleidingstypen. De erg hoge vervangingsvraag bij HBO lerarenopleiding talen weerspiegelt de hoge vervangingsbehoefte bij de beroepsgroep docenten talen en expressie en is met name het gevolg van de hoge arbeidsmarktuitstroom van oudere docenten. Ook bij WO theologie is de erg hoge vervangingsvraag evenals de afgelopen jaren vrijwel geheel toe te schrijven aan de hoge arbeidsmarktuitstroom van ouderen. 
Tabel 2.7

Opleidingstypen met relatief gezien de hoogste vervangingsvraag 1997-2002 (totaal aantal en gemiddeld jaarlijks percentage) en 1992-1996 (gemiddeld jaarlijks percentage)

Opleidingstype

VBO grafische techniek

MAVO

VBO installatietechniek

VBO verzorging

MBO/LLW laboratorium

VBO horeca en levensmiddelentechniek

HBO lerarenopleiding talen

MBO/LLW vliegtuigtechniek

W0 theologie

VBO mechanische techniek

HBO toerisme en recreatie

W0 civiele techniek
Prognose 1997-2002

aantal $\%$ typering

$\begin{array}{rrlll}1.900 & 5,8 & \text { erg hoog } & 6,4 & \text { erg hoog } \\ 122.500 & 5,4 & \text { erg hoog } & 6,4 & \text { erg hoog } \\ 2.900 & 5,2 & \text { erg hoog } & 7,2 & \text { erg hoog } \\ 51.900 & 5,2 & \text { erg hoog } & 4,1 & \text { gemiddeld } \\ 5.200 & 5,2 & \text { erg hoog } & 6,5 & \text { erg hoog } \\ 8.200 & 5,0 & \text { erg hoog } & 5,9 & \text { erg hoog } \\ 300 & 4,9 & \text { erg hoog } & 3,9 & \text { gemiddeld } \\ 1.700 & 4,9 & \text { erg hoog } & 4,2 & \text { hoog } \\ 1.500 & 4,8 & \text { erg hoog } & 3,7 & \text { gemiddeld } \\ 30.600 & 4,8 & \text { erg hoog } & 4,9 & \text { erg hoog } \\ 2.300 & 4,6 & \text { hoog } & 4,2 & \text { hoog } \\ 1.800 & 4,6 & \text { hoog } & 3,7 & \text { gemiddeld }\end{array}$

Bron: ROA

Evenals bij de beroepsgroepen met verhoudingsgewijs de laagste vervangingsbehoefte, is er vooral een erg lage vervangingsbehoefte bij de opleidingstypen, waarvoor de werkgelegenheid de laatste tijd het sterkst is gestegen. Bij deze opleidingstypen is het merendeel van de werkenden niet ouder dan 40 jaar. Naast degenen met een informatica-opleiding op WO-, HBO- of MBO-niveau gaat het daarbij om sterk uiteenlopende opleidingstypen, zoals $M B O / L L W$ toerisme en recreatie, VBO beveiliging en $H B O$ communicatie en journalistiek.

Tabel 2.8

Opleidingstypen met relatief gezien de laagste vervangingsvraag 1997-2002 (totaal aantal en gemiddeld jaarlijks percentage) en 1992-1996 (gemiddeld jaarlijks percentage)

Opleidingstype

$\mathrm{MBO} / \mathrm{LLW}$ toerisme en recreatie

VBO beveiliging

WO informatica en bestuurlijke informatiekunde HBO communicatie en journalistiek

Wo landbouw en milieukunde

HBO tolk en vertaler

MBO dokters-, tandarts- en dierenartsassistent

MBO/LIW milieu en groene ruimte

Wo farmacie

MBO/LLW procestechniek

$\mathrm{HBO}$ informatica

MBO/LLW beweging en therapie
Prognose 1997-2002

aantal \% typering

$\begin{array}{rrl}700 & 0,8 & \text { erg laag } \\ 1.000 & 1,6 & \text { erg laag } \\ 800 & 1,8 & \text { erg laag } \\ 1.700 & 2,0 & \text { erg laag } \\ 1.300 & 2,0 & \text { erg laag } \\ 1.000 & 2,1 & \text { erg laag } \\ 2.600 & 2,3 & \text { erg laag } \\ 3.100 & 2,5 & \text { laag } \\ 900 & 2.5 & \text { laag } \\ 3.400 & 2,6 & \text { laag } \\ 5.100 & 2,6 & \text { laag } \\ 3.800 & 2,8 & \text { laag }\end{array}$

1992-1996

$\% \quad$ typering

0,4 erg laag

3,5 gemiddeld

0,9 erg laag

1,8 erg laag

3,0 laag

1,6 erg laag

1,4 erg laag

2,2 erg laag

$2,8 \quad$ laag

1,5 erg laag

2,5 laag

2,3 erg laag

Bron: ROA 


\subsection{Baanopeningen}

\section{Beroepen}

De uitbreidingsvraag en de vervangingsvraag bepalen tezamen het aantal baanopeningen voor nieuwkomers op de arbeidsmarkt. In de prognoseperiode van 1997-2002 zal de totale werkgelegenheid naar verwachting met 610.000 werkenden toenemen. Tevens zullen in deze periode ruim 1.100 .000 werkenden de arbeidsmarkt verlaten. Dat betekent dat bijna $65 \%$ van alle baanopeningen voortkomt uit de behoefte om vertrekkend personeel te vervangen. De werkgevers zullen in sommige beroepsgroepen het vertrek van werknemers echter benutten om een teruglopende vraag naar de desbetreffende beroepsgroep te realiseren. Naar verwachting worden er de komende vijf jaar in totaal ruim 26 duizend vrijkomende arbeidsplaatsen niet opnieuw bezet, walardoor de totale vervangingsvraag naar beroepsklasse circa 1.075 .000 personen bedraag.

Tegenover deze krimpende werkgelegenheid in bepaalde beroepsklassen staat een groei van de werkgelegenheid in andere beroepsklassen van in totaal ruim 635.000 personen. Naar verwachting zal er derhalve de komende viff jaar in total in de verschillende beroepsklassen sprake zijn van ruim 1.685 .000 baanopeningen. $64 \%$ van deze baanopeningen kan worden toegeschreven aan de vervangingsvraag, terwijl $36 \%$ betrekking heeft op de uithreidingsvraag.

Tabel 2.9 geeft een overzicht van de beroepsgroepen waarvoor het aantal baanopeningen verhoudingsgewijs het grootst is. Het is opmerkelijk dat de tabel gedomineerd wordt door de beroepsgroepen met een relatief hoge uitbreidingsvraag, terwijl, zoals gezegd, de vervangingsvraag verantwoordelijk is voor verreweg de meeste baanopeningen. Echter, de verschillen in de uitbreidingsvraag voor de beroepsklassen zijn veel groter dan de onderlinge verschillen in de vervangingsbehoefte. Dit verklaart waarom maar liefst 10 van de 12 beroepsgroepen met relatief het grootste aantal baanopeningen ook tot de beroepsgroepen met de hoogste uitbreidingsvraig behoort (zie talbel 2.1). 1)e enige uitzonderingen zijn de materiaalkundigen en de cafe- en snackbarbouders. Alleen bij de laatste beroepsgroep is het merendeel van de verwachte batanopeningen toe te schrijven aan de vervangingsvraag.

De lijst wordt aangevoerd door dezelfde drie beroepsgroepen waarvoor de uithreidingsvraag verhoudingsgewijs het hoogst was: steuards, productieplanners en organisatie-adviseurs. Bij deze beroepsgroepen is het overgrote deel van de baanopeningen voor nieuwkomers in tegenstelling tot het algemene beeld het gevolg van de uithreidingsvraag. Bij alle drie beroepsgroepen was ook de afgelopen jaren het a antal baanopeningen erg hoog, eveneens met name vanwege de hoge uithreidingsvraag. Ook bij de andere beroepsgroepen die eveneens tot de sterkst groeiende beropsgroepen behoren, is het merendeel van de verwachte baanopeningen toe te schrijven aan de hoge uitbreidingsvraag. Bij de meeste van deze beroepsgroepen was zowel het aantal baanopeningen als de uitbreidingsvraag ook de afgelopen jaren (erg) hoog 
Tabel 2.9

Beroepsgroepen met relatief gezien het hoogste aantal baanopeningen 1997-2002 (totaal aantal en gemiddeld jaarlijks percentage) en 1992-1996 (gemiddeld jaarlijks percentage)

Beroepsgroep

Stewards

Productieplanners

Organisatie-adviseurs

Onderwijskundig medewerkers

Sociaal-wetenschappelijk medewerkers

Milieuhygiënisten en agrarisch

vertegenwoordigers

Materiaalkundigen

Bedriffshoofden metaalbewerking

Café-en snackbarhouders

Accountants

Ziekenverzorgenden

Organisatiedeskundigen

\begin{tabular}{|c|c|c|}
\hline \multicolumn{3}{|c|}{ Prognose 1997-2002 } \\
\hline aantal & $\%$ & typering \\
\hline 7.900 & 12,1 & erg hoog \\
\hline 33.000 & 10,6 & erg hoog \\
\hline 19.700 & 10,1 & erg hoog \\
\hline 5.100 & 10,1 & erg hoog \\
\hline 4.100 & 9,9 & erg hoog \\
\hline 7.800 & 9,0 & erg hoog \\
\hline 7.100 & 8,9 & erg hoog \\
\hline 2.300 & 8,9 & erg hoog \\
\hline 5.900 & 8,8 & erg hoog \\
\hline 14.100 & 8,7 & erg hoog \\
\hline 28.800 & 8,7 & hoog \\
\hline 9.400 & 8,6 & hoog \\
\hline
\end{tabular}

1992-1996

$\% \quad$ typering

9,9 erg hoog

18,5 erg hoog

9,2 erg hoog

6,9 hoog

1,0 erg laag

5,8 gemiddeld

3,9 gemiddeld

8,5 hoog

6,3 hoog

17,8 erg hoog

8,7 hoog

7,6 hoog

Bron: ROA

De ranglijst van de beroepsgroepen met het geringste aantal baanopeningen wordt in beperkte mate bepaald door de verschillen in de uitbreidingsvraag tussen de beroepsgroepen. Voor slechts 2 van de 12 in tabel 2.10 gepresenteerde beroepsgroepen wordt een krimpende werkgelegenheid verwacht. Bij deze beroepsgroepen is het aantal baanopeningen voor nieuwkomers geheel afhankelijk van de vervangingsvraag. Bij de agrarische vakkachten is er zowel een krimpende werkgelegenheid als een erg lage vervangingsbehoefte. Dit laatste mede vanwege het feit dat veel van het vertrekkend personeel vanwege de werkgelegenheidskrimp niet wordt vervangen door nieuwkomers. ook de afgelopen jaren was het aantal baanopeningen voor agrarische vakkrachten

Tabel 2.10

Beroepsgroepen met relatief gezien het laagste aantal baanopeningen 1997-2002 (totaal aantal en gemiddeld jaarlijks percentage) en 1992-1996 (gemiddeld jaarlijks percentage)

Beroepsgroep

Agrarische vakkrachten

Elektrotechnici

Werktuighouwkundigen

Landbouwmachinebestuurders en vissers

Grafisch productiepersoneel

Economen

Commercieel emplovés

Weg-en waterbouwkundige arbeiders

Politie-inspecteurs en officieren

Bibliotheckassistenten

Agrarische arbeiders

Vechanisch oper:mors

\section{Prognose 1997-2002}

aantal $\%$ typering

$\begin{array}{rll}1.100 & 2,2 & \text { erg laag } \\ 1.000 & 2,5 & \text { laag } \\ 1.900 & 2,9 & \text { laag } \\ 1.700 & 3,0 & \text { laag } \\ 4.000 & 3,0 & \text { laag } \\ 2.400 & 3,2 & \text { laag } \\ 45.800 & 3,2 & \text { laag } \\ 4.200 & 3,3 & \text { laag } \\ 900 & 3,3 & \text { laag } \\ 3.200 & 3,4 & \text { gemiddeld } \\ 19.800 & 3.4 & \text { gemiddeld } \\ 14.200 & 3.4 & \text { gemiddeld }\end{array}$

1992-1996

$\%$ typering

2,1 erg laag

3,2 laag

5,2 gemiddeld

2,8 laag

3,2 laag

4,2 gemiddeld

3,2 laag

4,3 gemiddeld

4,0 gemiddeld

9,6 erg hoog

5.0 gemiddeld

3.1 laag

Bron: $\mathrm{ROA}$ 
met name als gevolg van de krimpende werkgelegenheid erg laag. Opmerkelijk is het lage aantal baanopeningen dat verwacht wordt voor enkele hogere beroepsgroepen. Het gaat hierbij om de beroepsgroepen elektrotechnici, werktuigbouwkundigen, economen en politie-inspecteurs en officieren. Met name bij de werktuigbouwkundigen is het aantal baanopeningen ook veel lager dan in de afgelopen periode. Dit wordt veroorzaakt doordat zowel de vervangingsvraag als de uitbreidingsvraag in de periode 1992-1996 hoger waren dan in de prognoseperiode.

\section{Opleidingen}

Tabel 2.11 geeft een overzicht van de opleidingstypen waarvoor het aantal baanopeningen relatief groot is. Ook hier bepalen de verschillen in de uitbreidingsvraag tussen de verschillende opleidingstypen het beeld. Maar liefst negen van de twaalf opleidingstypen behoren tot de in tabel 2.3 weergegeven opleidingstypen met de hoogste uitbreidingsvraag. Bij al deze opleidingstypen is de uitbreidingsvraag verantwoordelijk voor het overgrote deel van de baanopeningen. Het gaat hier in de meeste gevallen om opleidingstypen die ook de afgelopen tijd sterk zijn gegroeid. Mede daardoor zijn de meeste werkenden met deze opleidingsachtergrond niet ouder dan 40 jaar, waardoor de vervangingsbehoefte nog niet erg groot is. Bij de meeste van deze opleidingstypen was het aantal baanopeningen ook de afgelopen jaren relatief hoog. Slechts bij drie opleidingstypen is het relatief hoge aantal baanopeningen het gevolg van de (erg) hoge vervangingsbehoefte: $M B O / L L W$ laboratorium, HBO toerisme en recreatie en WO civiele techniek. Bij MBO/LLW laboratorium en WO civiele techniek is de vervangingsvraag ook verantwoordelijk voor het merendeel van de verwachte baanopeningen. Bij $H B O$ toerisme en recreatie is de helft van de baanopeningen het gevolg van de uitbreidingsvraag. Met name bij WO civiele techniek ligt het aantal baanopeningen op een alanzienlijk hoger niveau dan in de afgelopen jaren. Dit is vooral het gevolg van het sterk aantrekken van de uitbreidingsvraag, hoewel ook de vervangingsvraag voor dit opleidingstype de komende jaren hoger zal zijn dan de afgelopen periode.

Tabel 2.11

Opleidingstypen met relatief gezien het hoogste aantal baanopeningen 1997-2002 (totaal aantal en gemiddeld jaarlijks percentage) en 1992-1996 (gemiddeld jaarlijks percentage)

\section{Opleidingstype}

WO informatica en bestuurlijke informatiekunde

WO bedrijfskunde

WO econom(etr)ie

WO accountancy en belastingen

$\mathrm{HBO}$ landbouw en veeteelt

WO bouwkunde

$\mathrm{HBO}$ recht en bestuur

$\mathrm{HBO}$ toerisme en recreatie

MBO/LLWW laboratorium

WO civiele techniek

HBO commerciële economie

MBO/LLW apothekersassistent

$\begin{array}{ccc}\text { Prognose } & \text { 1997-2002 } \\ \text { aantal } & \% & \text { typering }\end{array}$

$\begin{array}{rrl}5.500 & 11,6 & \text { erg hoog } \\ 13.500 & 11,2 & \text { erg hoog } \\ 24.500 & 10,4 & \text { erg hoog } \\ 10.600 & 10,3 & \text { erg hoog } \\ 4.800 & 10,2 & \text { hoog } \\ 4.900 & 9,5 & \text { hoog } \\ 11.300 & 9,3 & \text { hoog } \\ 4.600 & 9,2 & \text { hoog } \\ 9.000 & 9,0 & \text { hoog } \\ 3.400 & 8,8 & \text { hoog } \\ 19.800 & 8,7 & \text { hoog } \\ 7.700 & 8,3 & \text { hoog }\end{array}$

1992-1996

$\% \quad$ typering

$\begin{aligned} 20,5 & \text { erg hoog } \\ 19,1 & \text { erg hoog } \\ 12,6 & \text { erg hoog } \\ 14,7 & \text { erg hoog } \\ 17,5 & \text { erg hoog } \\ 3,3 & \text { laag } \\ 9,1 & \text { hoog } \\ 12,5 & \text { erg hoog } \\ 6,6 & \text { gemiddeld } \\ 3,7 & \text { laag } \\ 10,7 & \text { erg hoog } \\ 7,5 & \text { gemiddeld }\end{aligned}$


De opleidingstypen met relatief gezien het kleinste aantal baanopeningen worden in tabel 2.12 in beeld gebracht. Bij maar liefst 10 van de 12 opleidingstypen is het geringe aantal baanopeningen toe te schrijven aan de negatieve uitbreidingsvraag. Alleen voor de opleidingstypen $H B O$ lerarenopleiding lichamelijke opvoeding en $M B O / L L W$ grafische techniek wordt een zeer geringe positieve uitbreidingsvraag verwacht. Bij het opleidingstype met het geringste aantal baanopeningen - WO farmacie - is ook de verwachte vervangingsvraag laag. Overigens ligt het aantal baanopeningen voor dit opleidingstype op een duidelijk lager niveau dan in de afgelopen periode. Bij de meeste andere opleidingstypen is het verwachte geringe aantal baanopeningen een voortzetting van de ontwikkeling van de afgelopen jaren.

Tabel 2.12

Opleidingstypen met relatief gezien het laagste aantal baanopeningen 1997-2002 (totaal aantal en gemiddeld jaarlijks percentage) en 1992-1996 (gemiddeld jaarlijks percentage)

\section{Opleidingstype}

Wo farmacie

HBO lerarenopleiding lichamelijke opvoeding

HBO personeelswerk

MBO/LLW grafische techniek

VBO fijnmechanische techniek

VBO administratie, handel en textiel

MBO/LLW brood en banket

VBO brood en banket

VBO landbouw en natuurlijke omgeving

VBO motorvoertuigentechniek

MBO/LLW verzorging

WO (dier)geneeskunde

$\begin{array}{lll}\text { Prognose } & \text { 1997-2002 } \\ \text { aantal } & \% & \text { typering }\end{array}$

$900 \quad 2,5 \quad$ laag

$2.600 \quad 3,2 \quad$ laag

$3.300 \quad 3.2 \quad$ laag

$\begin{array}{lll}7.400 & 3.5 & \text { laag }\end{array}$

$\begin{array}{lll}1.000 & 3,5 & \text { laag }\end{array}$

$23.200 \quad 3,6 \quad$ laag

$2.800 \quad 3,6 \quad$ laag

$\begin{array}{lll}2.500 & 3,7 \quad \text { laag }\end{array}$

$\begin{array}{lll}15.200 & 3.8 \quad \text { lag }\end{array}$

$8.400 \quad 3,8 \quad$ laag

$39.200 \quad 3,9 \quad$ laag

$9.800 \quad 4,2 \quad$ laag
1992-1996

$\% \quad$ typering

5,8 gemiddeld

7,3 gemiddeld

$3,9 \quad$ laag

3,4 laag

5,2 gemiddeld

$3,7 \quad$ laag

$2,6 \quad$ laag

$3,7 \quad$ laag

5.1 gemiddeld

4,1 laag

2,5 laag

4,8 gemiddeld

Bron: ROA 


\section{Uitgelicht: Docenten}

In verschillende docentenberoepen in met name het voortgezet onderwijs, zal de werkgelegenheid de komende jaren krimpen. Het gaat hierbij vooral om docentenfuncties op 2e graadsniveau. Dat betekent echter niet dat er in de komende jaren weinig baanopeningen voor docenten zullen zijn. De vervangingsbehoefte naar een aantal docentenberoepen is namelijk vrij groot. Deze erg hoge vervangingsvraag is vooral te wijten aan de vergrijzing van de werkenden in de docentenberoepen.

De verwachte werkgelegenheidskrimp in de docentenberoepen is het gevolg van ontwikkelingen op uiteenlopende terreinen. Op demografisch vlak draagt de ontgroening ertoe bij dat er in de toekomst minder docenten nodig zullen zijn. Daarnaast is er sprake van een veranderend keuzegedrag van scholieren en studenten, al dan niet in relatie tot het gevoerde onderwijsbeleid. Vooral bij de beroepen docenten sociale vakken en docenten talen en expressie zou dit een rol kunnen spelen.

De komende jaren zal de uitbreidingsvraag voor de meeste onderscheiden lerarenopleidingen laag zijn. Bij de HBO lerarenopleiding talen zal de vraag de komende jaren zelfs met gemiddeld $2 \%$ dalen. Voor de HBO lerarenopleidingen lichamelijke opvoeding, medisch en verzorging en expressie wordt de komende jaren een positieve, maar lage uitbreidingsvraag verwacht. Alleen voor de lerarenopleiding basisonderwijs en de lerarenopleiding economie en maatschappij wordt een 'gemiddelde' uitbreidingsvraag verwacht van respectievelijk 2,3 en $3,1 \%$ per jaar.

De arbeidsmarktinstroom uit de lerarenopleidingen is echter in het algemeen ook laag: alle HBO lerarenopleidingen vallen dan ook in de groep van de 25 opleidingen met de laagste arbeidsmarktinstroom. In combinatie met de over het algemeen hoge vervangingsvraag en de lage uitbreidingsvraag zorgt deze lage instroom ervoor dat de perspectieven van deze opleidingstypen goed of zeer goed genoemd kunnen worden. De keerzijde daarvan is dat de onderwijssector voor alle onderscheiden lerarenopleidingen geconfronteerd zal worden met grote knelpunten in de personeelsvoorziening.

\subsection{Arbeidsmarktinstroom}

Om een beeld te kunnen vormen van de toekomstige arbeidsmarktsituatic moeten naast de in cle vorige paragrafen beschreven vraagontwikkelingen ook de ontwikkelingen aan de aanbodzijde van de arbeidsmarkt in beeld gebracht worden. Natast het aan het hegin van de prognoseperiode boven de markt zwevende aanbod van kortdurig werklozen gaat het daarbij vooral om de voor de komende jaren verwachte arbeidsmarktinstroom van schoolverlaters. Daarbij moet rekening worden gehouden met zowel de arbeidsmarktinstroom van schoolverlaters vanuit het initiële dagonderwijs, als de veranderingen die er in de opleidingsachtergrond van het arbeidsatanbod optreden door het volgen van opleidingen nadat men de arbeidsmarkt heeft betreden. In totaal 
zullen naar verwachting in vijf jaar tijd bijna 1.400 .000 schoolverlaters op de arbeidsmarkt instromen. Daarmee kan jaarlijks gemiddeld 4,3\% van de werkzame bevolking worden ververst, een iets lager percentage dan in de afgelopen jaren.

Tussen de onderscheiden opleidingstypen zijn er aanzienlijke verschillen in de arbeidsmarktinstroom van schoolverlaters. Tabel 2.13 geeft een overzicht van de opleidingstypen waarvoor de verwachte instroom van schoolverlaters relatief gezien in de periode 1997-2002 het grootst zal zijn. Uit de tabel blijkt dat er op alle opleidingsniveaus opleidingen voorkomen waarbij de arbeidsmarktinstroom van schoolverlaters erg hoog is. De tabel geeft in feite een beeld van de opleidingen die de laatste jaren relatief populair zijn bij de studiekeuze. Daarbij gaat het vanzelfsprekend vaak ook om opleidingen die relatief nieuw zijn, waardoor er nog betrekkelijk weinig werkenden zijn met de desbetreffende opleidingsachtergrond. Een duidelijk voorbeeld van dergelijke populaire opleidingen zijn $M B O / L L W$ toerisme en recreatie en $H B O$ toerisme en recreatie. In het kader op pagina 28 wordt nader op deze opleidingstypen ingegaan. Op MBO/LLWniveau bedraagt de jaarlijkse arbeidsmarktinstroom bij dit opleidingstype maar liefst ruim $9 \%$ van het totaal aantal werkenden met deze opleidingsachtergrond. Opmerkelijk is wel dat de arbeidsmarktinstroom bij beide opleidingstypen de komende jaren op een aanzienlijk lager niveau ligt dan de afgelopen jaren. HBO toerisme en recreatie behoort tezamen met HAVO/VWO en VBO horeca en levensmiddelentechniek ook tot de opleidingstypen waarbij een slechte actuele arbeidsmarktsituatie (zie paragraaf 3.1) gepaard gaat met een (erg) hoge arbeidsmarktinstroom. Wel ligt bij alle drie opleidingstypen de arbeidsmarktinstroom de komende tijd op een lager niveau dan in de afgelopen jaren.

Tabel 2.13

Opleidingstypen met relatief gezien de hoogste instroom 1997-2002 (totaal aantal en gemiddeld jaarlijks percentage) en 1992-1996 (gemiddeld jaarlijks percentage)

Opleidingstype

MBO/LIW toerisme en recreatie

HBO commerciële economie

VBO installatietechniek

HAVONWO

HBO personeelswerk

Wo kunstwetenschappen

HBO toerisme en recreatie

MBO socialal-cultureel

HBO bedrijfskunde

MBO/LIIW laboratorium

Wo econom(etr)ie

VBO horeca en levensmiddelentechniek

$\begin{array}{ccc}\text { Prognose } & \text { 1997-2002 } \\ \text { aantal } & \% & \text { typering }\end{array}$

$\begin{array}{rrlrl}10.000 & 9,1 & \text { erg hoog } & 18,9 & \text { erg hoog } \\ 20.200 & 8,2 & \text { erg hoog } & 11,4 & \text { erg hoog } \\ 4.600 & 7,9 & \text { erg hoog } & 11,0 & \text { erg hoog } \\ 148.900 & 7,9 & \text { erg hoog } & 10,7 & \text { erg hoog } \\ 8.700 & 7,9 & \text { erg hoog } & 5,7 & \text { hoog } \\ 2.100 & 7,6 & \text { erg hoog } & 11,6 & \text { erg hoog } \\ 4.000 & 7,6 & \text { erg hoog } & 11,4 & \text { erg hoog } \\ 25.100 & 7,3 & \text { erg hoog } & 8,7 & \text { erg hoog } \\ 26.700 & 7,1 & \text { erg hoog } & 10,3 & \text { erg hoog } \\ 7.400 & 7,1 & \text { erg hoog } & 10,1 & \text { erg hoog } \\ 16.700 & 6,9 & \text { erg hoog } & 11,9 & \text { erg hoog } \\ 11.200 & 6,7 & \text { hoog } & 7,7 & \text { erg hoog }\end{array}$

Bron: ROA

Erg populair zijn ook de HBO-opleidingen commerciële economie, personeelsuerk en bedrijfskunde. Alleen bij HBO personeelswerk is er daarbij sprake van een toename van de arbeidsmarktinstrom in vergelijking met de afgelopen jaren. Op VBO-niveau is de arbeidsmarktinstroom, gezien de in het algemeen lage belangstelling voor het VBO. opmerkelijk hoog bij de opleidingstypen VBO installatietechniek en VBO boreca en 
levensmiddelentechniek. Dit geldt temeer voor het laatstgenoemde opleidingstype, waarvoor zoals gezegd de actuele arbeidsmarktsituatie weinig rooskleurig is. Op MBOniveau zijn naast toerisme en recreatie vooral de opleidingstypen $M B O$ sociaal-cultureel en $M B O / L L W$ laboratorium relatief populair, terwijl op universitair niveau de opleidingstypen WO kunstwetenschappen en WO econom(etr)ie de relatief hoogste arbeidsmarktinstroom hebben. Bij beide laatstgenoemde opleidingstypen ligt de arbeidsmarktinstroom de komende jaren naar verwachting echter op een aanzienlijk lager niveau dan in de afgelopen jaren.

Tabel 2.14 geeft een overzicht van de opleidingstypen waarvoor de arbeidsmarktinstroom in de prognoseperiode relatief gezien het laagst is. Ook in deze tabel zijn alle opleidingsniveaus vertegenwoordigd. Wel zijn er opvallend veel HBO-opleidingen met een relatief (erg) lage arbeidsmarktinstroom. Bij de opleidingstypen $H B O$ recht en bestuur en $H B O$ tolk en vertaler hangt de geringe populariteit van de opleidingen mogelijk samen met de slechte actuele arbeidsmarktsituatie.

Tabel 2.14

Opleidingstypen met relatief gezien de laagste instroom 1997-2002 (totaal aantal en gemiddeld jaarlijks percentage) en 1992-1996 (gemiddeld jaarlijks percentage)

Opleidingstype
HBO recht en bestuur
HBO lerarenopleiding medisch en verzorging
WO accountancy en belastingen
VBO fijnmechanische techniek
WO tandheelkunde
HBO tolk en vertaler
HBO lerarenopleiding natuur en techniek
MBO/LLW verpleging
HBO vervoer en logistiek
WO theologie
HBO lerarenopleiding basisonderwijs
HBO lerarenopleiding talen

Bron: ROA

\begin{tabular}{|c|c|c|c|c|}
\hline \multicolumn{3}{|c|}{ Prognose 1997-2002 } & \multicolumn{2}{|c|}{ 1992-1996 } \\
\hline aantal & $\%$ & typering & $\%$ & typering \\
\hline 300 & 0,2 & erg laag & 3,0 & gemiddeld \\
\hline 700 & 1,0 & erg laag & 1,6 & laag \\
\hline 900 & 1,0 & erg laag & 1,8 & laag \\
\hline 300 & 1,1 & erg laag & 2,1 & laag \\
\hline 400 & 1,3 & laag & 2,0 & laag \\
\hline 600 & 1,4 & laag & 2,2 & laag \\
\hline 2.700 & 1,5 & laag & 1,8 & laag \\
\hline 9.400 & 1,5 & laag & 2,0 & laag \\
\hline 1.900 & 1,5 & laag & 2,5 & laag \\
\hline 600 & 2,0 & laag & 2,9 & gemiddel \\
\hline 17.100 & 2,1 & laag & 2,9 & gemiddeld \\
\hline 3.300 & 2,1 & laag & 1,5 & laag \\
\hline
\end{tabular}

Dalarnast is op HBO-niveau de verwachte arbeidsinstroom de komende jaren (erg) laag voor de lerarenopleidingen in de richtingen medisch en verzorging, natum en lechniek, basisonderwijs en talen. Ook voor het opleidingstype HBO vertoer en logistiek wordt een lage instroom verwacht. Bij al deze opleidingstypen lag cle arbeidsmarktinstroom ook de afgelopen jaren al op een relatief laag peil. Op MBO-niveau is de arbeidsmarktinstroom de komende jaren vooral laag bij het op de gezondheids\%org gerichte opleidingstype $M B O / L W$ verpleging. Op VBO-niveau is de verwachte arbeidsmarktinstroom het geringst bij het opleidingstype VBO fijmmechanische lechniek, terwijl op universitair niveau de arbeidsmarktinstroom (erg) laag is bij WO accombancy) en belastingen en het door een arbeidsmarktfixus gereguleerde opleidingstype Wo tandheelkunde. 
zullen naar verwachting in vijf jaar tijd bijna 1.400 .000 schoolverlaters op de arbeidsmarkt instromen. Daarmee kan jaarlijks gemiddeld 4,3\% van de werkzame bevolking worden ververst, een iets lager percentage dan in de afgelopen jaren.

Tussen de onderscheiden opleidingstypen zijn er aanzienlijke verschillen in de arbeidsmarktinstroom van schoolverlaters. Tabel 2.13 geeft een overzicht van de opleidingstypen waarvoor de verwachte instroom van schoolverlaters relatief gezien in de periode 1997-2002 het grootst zal zijn. Uit de tabel blijkt dat er op alle opleidingsniveaus opleidingen voorkomen waarbij de arbeidsmarktinstroom van schoolverlaters erg hoog is. De tabel geeft in feite een beeld van de opleidingen die de laatste jaren relatief populair zijn bij de studiekeuze. Daarbij gaat het vanzelfsprekend vaak ook om opleidingen die relatief nieuw zijn, waardoor er nog betrekkelijk weinig werkenden zijn met de desbetreffende opleidingsachtergrond. Een duidelijk voorbeeld van dergelijke populaire opleidingen zijn $M B O / L L W$ toerisme en recreatie en $H B O$ toerisme en recreatie. In het kader op pagina 28 wordt nader op deze opleidingstypen ingegaan. Op MBO/LLWniveau bedraagt de jaarlijkse arbeidsmarktinstroom bij dit opleidingstype maar liefst ruim 9\% van het totaal aantal werkenden met deze opleidingsachtergrond. Opmerkelijk is wel dat de arbeidsmarktinstroom bij beide opleidingstypen de komende jaren op een aanzienlijk lager niveau ligt dan de afgelopen jaren. HBO toerisme en recreatie behoort tezamen met HAVO/VWO en VBO horeca en levensmiddelentechniek ook tot de opleidingstypen waarbij een slechte actuele arbeidsmarktsituatie (zie paragraaf 3.1) gepaard gaat met een (erg) hoge arbeidsmarktinstroom. Wel ligt bij alle drie opleidingstypen de arbeidsmarktinstroom de komende tijd op een lager niveau dan in de afgelopen jaren.

Tabel 2.13

Opleidingstypen met relatief gezien de hoogste instroom 1997-2002 (totaal aantal en gemiddeld jaarlijks percentage) en 1992-1996 (gemiddeld jaarlijks percentage)

Opleidingstype

MBO/LIW toerisme en recreatie

HBO commerciële economie

VBO installatietechniek

HAVONWO

HBO personeelswerk

Wo kunstwetenschappen

HBO toerisme en recreatie

MBO sociaal-cultureel

HBO bedrijfskunde

MBO/LLW laboratorium

WO econom(etr) ie

VBO horeca en levensmiddelentechniek

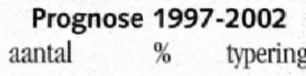

$\begin{array}{rrlrl}10.000 & 9,1 & \text { erg hoog } & 18,9 & \text { erg hoog } \\ 20.200 & 8,2 & \text { erg hoog } & 11,4 & \text { erg hoog } \\ 4.600 & 7,9 & \text { erg hoog } & 11,0 & \text { erg hoog } \\ 148.900 & 7,9 & \text { erg hoog } & 10,7 & \text { erg hoog } \\ 8.700 & 7,9 & \text { erg hoog } & 5,7 & \text { hoog } \\ 2.100 & 7,6 & \text { erg hoog } & 11,6 & \text { erg hoog } \\ 4.000 & 7,6 & \text { erg hoog } & 11,4 & \text { erg hoog } \\ 25.100 & 7,3 & \text { erg hoog } & 8,7 & \text { erg hoog } \\ 26.700 & 7,1 & \text { erg hoog } & 10,3 & \text { erg hoog } \\ 7.400 & 7,1 & \text { erg hoog } & 10,1 & \text { erg hoog } \\ 16.700 & 6,9 & \text { erg hoog } & 11,9 & \text { erg hoog } \\ 11.200 & 6,7 & \text { hoog } & 7,7 & \text { erg hoog }\end{array}$

1992-1996

$\% \quad$ typering

18,9 erg hoog

11,4 erg hoog

$11,0 \quad$ erg hoog

$0,7 \quad$ erg hoog

hoog

hoog

rg hoog

rg hoog

hoog

hoog

Bron: ROA

Erg populair zijn ook de HBO-opleidingen commerciële economie, personeelsuerk en bedrijfskunde. Alleen bij HBO personeelswerk is er daarbij sprake van een toename van de arbeidsmarktinstroom in vergelijking met de afgelopen jaren. Op VBO-niveau is de arbeidsmarktinstroom, gezien de in het algemeen lage belangstelling voor het VBO, opmerkelijk hoog bij de opleidingstypen VBO installatietechniek en VBO boreca en 
levensmiddelentechniek. Dit geldt temeer voor het laatstgenoemde opleidingstype, waarvoor zoals gezegd de actuele arbeidsmarktsituatie weinig rooskleurig is. Op MBOniveau zijn naast toerisme en recreatie vooral de opleidingstypen $M B O$ sociaal-cultureel en $M B O / L L W$ laboratorium relatief populair, terwijl op universitair niveau de opleidingstypen WO kunstwetenschappen en WO econom(etr)ie de relatief hoogste arbeidsmarktinstroom hebben. Bij beide laatstgenoemde opleidingstypen ligt de arbeidsmarktinstroom de komende jaren naar verwachting echter op een aanzienlijk lager niveau dan in de afgelopen jaren.

Tabel 2.14 geeft een overzicht van de opleidingstypen waarvoor de arbeidsmarktinstroom in de prognoseperiode relatief gezien het laagst is. Ook in deze tabel zijn alle opleidingsniveaus vertegenwoordigd. Wel zijn er opvallend veel $\mathrm{HBO}$-opleidingen met een relatief (erg) lage arbeidsmarktinstroom. Bij de opleidingstypen HBO recht en bestuur en $H B O$ tolk en vertaler hangt de geringe populariteit van de opleidingen mogelijk samen met de slechte actuele arbeidsmarktsituatie.

Tabel 2.14

Opleidingstypen met relatief gezien de laagste instroom 1997-2002 (totaal aantal en gemiddeld jaarlijks percentage) en 1992-1996 (gemiddeld jaarlijks percentage)

Opleidingstype
HBO recht en bestuur
HBO lerarenopleiding medisch en verzorging
WO accountancy en belastingen
VBO fijnmechanische techniek
WO tandheelkunde
HBO tolk en vertaler
HBO lerarenopleiding natuur en techniek
MBO/LLW verpleging
HBO vervoer en logistiek
WO theologie
HBO lerarenopleiding basisonderwijs
HBO lerarenopleiding talen

Bron: ROA

\begin{tabular}{rcccc}
\multicolumn{2}{c}{$\begin{array}{c}\text { Prognose } \\
\text { 19antal }\end{array}$} & $\%$ & typering & \multicolumn{2}{c}{$\mathbf{1 9 9 2}$-1996 } \\
\% & typering \\
300 & 0,2 & erg laag & 3,0 & gemiddeld \\
700 & 1,0 & erg laag & 1,6 & laag \\
900 & 1,0 & erg laag & 1,8 & laag \\
300 & 1,1 & erg laag & 2,1 & laag \\
400 & 1,3 & laag & 2,0 & laag \\
600 & 1,4 & laag & 2,2 & laag \\
2.700 & 1,5 & laag & 1,8 & laag \\
9.400 & 1,5 & laag & 2,0 & laag \\
1.900 & 1,5 & laag & 2,5 & laag \\
600 & 2,0 & laag & 2,9 & gemiddeld \\
17.100 & 2,1 & laag & 2,9 & gemiddeld \\
3.300 & 2,1 & laag & 1,5 & laag
\end{tabular}

Daarnaast is op HBO-niveau de verwachte arbeidsinstroom de komende jaren (erg) laag voor de lerarenopleidingen in de richtingen medisch en verzorging, natum en techniek, basisonderwijs en talen. Ook voor het opleidingstype HBO vertwer en logistiek wordt een lage instroom verwacht. Bij al deze opleidingstypen lag de arbeidsmarktinstroom ook de afgelopen jaren al op een relatief laag peil. Op MBO-niveau is de arbeidsmarktinstroom de komende jaren vooral laag bij het op de gezondheidszorg gerichte opleidingstype $M B O / L L W$ verpleging. Op VBO-niveau is de verwachte arbeidsmarktinstroom het geringst bij het opleidingstype VBO fijnmechanische lechniek, terwijl op universitair niveau de arbeidsmarktinstroom (erg) laag is bij WO accontantay' en belastingen en het door een arbeidsmarktfixus gereguleerde opleidingstype W() tandheelkunde. 


\section{Uitgelicht: $\mathrm{MBO}$ en $\mathrm{HBO}$ toerisme en recreatie}

De opleiding $M B O / L L W$ toerisme en recreatie blijt een erg populaire opleiding. Hoewel de arbeidsmarktinstroom van schoolverlaters met deze opleidingsachtergrond in vergelijking met de periode 1992-1996 vrij fors daalt, zal het jaarlijkse instroompercentage de komende vijf jaar toch nog ruim $9 \%$ per jaar bedragen; dat is het hoogste instroompercentage van alle 113 onderscheiden opleidingstypen. Ook toerisme en recreatie op HBO-niveau kent een hoge arbeidsmarktinstroom. In de periode 1997-2002 zal op jaarbasis maar liefst 7,6\% van het aantal werkenden met opleidingsachtergrond $H B O$ toerisme en recreatie op de arbeidsmarkt instromen.

Beide opleidingstypen zijn nog relatief nieuw, waardoor er nog weinig werkenden zijn met een opleiding toerisme en recreatie op $\mathrm{MBO} / \mathrm{LLW}$ - of $\mathrm{HBO}-$ niveau. Voor beide toeristische opleidingstypen zal de uitbreidingsvraag ook de komende jaren hoog zijn. Daarbij gaat het om een uitbreidingsvraag van rond de 4,5\%. Op grond van het feit dat beide opleidingen nog relatief nieuw zijn zou een lage vervangingsvraag verwacht mogen worden. Voor $M B O / L L W$ toerisme en recreatie is dat inderdaad het geval. Hier bedraagt de vervangingsvraag op jaarbasis slechts $0,8 \%$. Voor HBO toerisme en recreatie geldt dat echter niet, ondanks het feit dat er in de werkzame bevolking met deze opleidingsachtergrond nog weinig of geen vergrijzing heeft plaatsgevonden. Er is sprake van een hoge vervangingsvraag van jaarlijks 4,6\%. De vervangingsvraag is voor dit opleidingstype echter niet alleen het gevolg van de arbeidsmarktuitstroom, maar ook doordat werkenden door het afronden van een deeltijdopleiding een andere opleidingskwalificatie krijgen. Ook voor HBO toerisme en recreatie is de vervangingsvraag met 3,2\% 'laag' wanneer dit doorstroomeffect niet wordt meegerekend.

Wanneer de geschetste vraag- en aanbodontwikkelingen tegen elkaar worden afgezet blijkt dat het perspectief voor de nieuwkomers op de arbeidsmarkt met de opleidingsachtergrond $M B O / L L W$ toerisme en recreatie 'slecht' is. Het arbeidsmarktperspectief voor HBO toerisme en recreatie is daarentegen 'redelijk'. In vergelijking met de $M B O / L L W$ toerisme en recreatie opleiding heeft deze opleiding een iets beter perspectief doordat de instroom lager is terwijl de vervangingsvraag mede door de eerder genoemde doorstroomeffecten wat hoger is.

\subsection{Substitutie-effecten}

Bij de in paragraal 2.1 in beeld gebrachte uitbreidingsvraag naar opleidingstype is rekening gehouden met de te verwachten verschuivingen in de opleidingenstructuur van beroepen. Dergelijke verschuivingen blijken valk het karakter te hebben van een upgrading van de opleidingseisen voor bepaalde beroepsgroepen. De opleidingsachtergrond van de werkenden in een bepaalde beroepsgroep kan echter ook beïnveed worden door de valag-alanbod-verhoudingen op de arbeidsmarkt. Zo zal bij sommige opleidingstypen het arbeidsabubod de valag ovetreffen, terwij bij andere opleidingstypen de vraiag groter is dan het arbeidsainbod. De arbeidsmarkt blijkt in de praktijk ratak voldoende flexibiliteit te hebben om een deel van deze onevenwichtigheden op te vangen. Degenen met een opleidingsachtergrond waarvoor een overschotsituatie 
geldt, wijken uit naar andere beroepsgroepen, waarbij ze genoegen nemen met een minder gunstige beloning en minder gunstige arbeidsvoorwaarden. Bij een aanbodtekort kan men daarentegen juist meer eisen stellen aan het werk dat men zoekt. Werkgevers die in dat geval geconfronteerd worden met recruteringsproblemen zullen bij het aantrekken van personeel mogelijk uitwijken naar mensen met een andere opleidingsachtergond.

Wanneer arbeidskrachten bij een aanbodoverschot uitwijken naar andere beroepsgroepen zullen er concessies gedaan worden met betrekking tot het soort werk dat verricht wordt en de beloning ervan. Deze actieve substitutie is daarmee een uitingsvorm van de scheve vraag-aanbod-verhouding. Om die reden wordt deze uitwijk niet meegerekend bij de bepaling van het arbeidsmarktperspectief en de kans op knelpunten in de personeelsvoorziening. Het gaat er hier immers om een consequentie van de aansluitingsproblemen tussen vraag en aanbod op de arbeidsmarkt aan het licht te brengen.

Bij de opleidingstypen die door andere opleidingstypen met een aanbodoverschot worden verdrongen, zal het feitelijke aantal baanopeningen als gevolg van dit verdringingsproces echter kleiner worden, terwijl opleidingstypen die verwant zijn aan de opleidingstypen met een aanbodtekort juist extra baanmogelijkheden zullen krijgen. Deze passieve-substitutie-effecten zijn daarom wel van belang voor de arbeidsmarktperspectieven van de schoolverlaters van deze opleidingen en moeten derhalve bij de prognoses van deze opleidingen worden meegenomen.

Tabel 2.15

Opleidingstypen die relatief sterk profiteren van aanbodtekorten bij concurrerende opleidingen: passieve substitutie-effecten (totaal aantal en gemiddeld jaarlijks percentage)

Opleidingstype

WO werktuigbouwkunde

WO bouwkunde

WO civiele techniek

WO informatica en bestuurlijke informatiekunde

WO rechten en bestuurskunde

$\mathrm{HBO}$ openbare orde en veiligheid

WO bedrijfskunde

wo landbouw en milieukunde

Wo econom(etr)ie

Wo elektrotechniek

WO wiskunde en natuurwetenschappen

$\mathrm{HBO}$ civiele techniek

\section{Prognose 1997-2002}

aantal $\%$ typering

$\begin{array}{rrr}1.500 & 2,9 & \text { erg hoog } \\ 1.400 & 2,8 & \text { erg hoog } \\ 1.000 & 2,6 & \text { erg hoog } \\ 800 & 2,0 & \text { erg hoog } \\ 5.000 & 1,7 & \text { erg hoog } \\ 800 & 1,6 & \text { erg hoog } \\ 1.700 & 1,6 & \text { erg hoog } \\ 800 & 1,2 & \text { erg hoog } \\ 2.500 & 1,2 & \text { erg hoog } \\ 500 & 1,1 & \text { erg hoog } \\ 3.200 & 1,0 & \text { hoog } \\ 800 & 0,9 & \text { hoog }\end{array}$

\section{$1992-1996$}

$\% \quad$ typering

4,1 erg hoog

3,8 erg hoog

3,7 erg hoog

7.9 erg hoog

3,8 erg hoog

3.3 erg hoog

6,7 erg hoog

3,1 erg hoog

4,8 erg hoog

3.5 erg hoog

2,2 erg hoog

1,7 erg hoog

Bron: ROA

Tabel 2.15 geeft een beeld van de opleidingstypen die het meest profiteren van de aan bodtekorten bij andere opleidingstypen. Wit de tabel blijkt duidelijk dat er vooral bij de universitaire technische opleidingen sprake is van een extra vratg vanwege de tekorten aan mensen met een verwante opleidingsachtergrond. Deze positicve passiene-substitutie-effecten lijken zich te concentreren bij een drietal clusters binnen het hoger onderwijs: de informatica- en elektrotechniek-opleidingen, de bouwkunde- en civicte-ted, 
niek-studies en de economische, bedrijfskundige en bestuurskundige opleidingsrichtingen. Naar verwachting zijn deze additionele vraageffecten overigens iets kleiner dan in de afgelopen jaren.

Tabel 2.16 geeft een overzicht van de opleidingstypen die het meest te kampen zullen hebben met de verdringing door andere opleidingen, waarvoor een aanbodoverschot wordt verwacht. Uit de tabel blijkt duidelijk dat deze verdringingseffecten zich, in tegenstelling tot de in tabel 2.15 gepresenteerde positieve passieve substitutie-effecten, met name voordoen bij de lager opgeleiden. Daarbij gaat het vooral om de technische opleidingen op VBO-niveau en de MAVO'ers, die verdrongen worden door arbeidskrachten met basisonderwijs, HAVO/VWO of de opleiding VBO administratie, handel en textiel. Voor de meeste MBO-opleidingen geldt dat een groot gedeelte van de verdringingseffecten afkomstig is van HAVO- en VWO'ers.

Tabel 2.16

Opleidingstypen die relatief in sterke mate door andere opleidingstypen worden verdrongen: passieve substitutie-effecten (totaal aantal en gemiddeld jaarlijks percentage)

Opleidingstype

VBO bouwtechniek

VBO installatietechniek

MBO/LIW levensmiddelentechniek/vleesverwerking

MAVO

VBO mechanische techniek

VBO fijnmechanische techniek

MBO/LLW landbouw en veeteelt

HBO toerisme en recreatie

MBO/LLW toerisme en recreatie

MBO/LLW bouw

MBO/LLW vervoer

$\mathrm{MBO} / \mathrm{LLW}$ secretariaat

Bron: ROA

\begin{tabular}{rrlll}
\multicolumn{3}{c}{ Prognose } & $\mathbf{1 9 9 7 - 2 0 0 2}$ & \multicolumn{2}{c}{$\mathbf{1 9 9 2}-\mathbf{1 9 9 6}$} \\
aantal & $\%$ & typering & $\%$ & typering \\
& & & & \\
-10.600 & $-1,6$ & erg laag & $-2,9$ & erg laag \\
-700 & $-1,5$ & erg laag & $-2,1$ & erg laag \\
-1.100 & $-1,0$ & erg laag & $-1,5$ & erg laag \\
-18.400 & $-0,9$ & erg laag & $-0,7$ & laag \\
-4.900 & $-0,9$ & laag & $-1,8$ & erg laag \\
-200 & $-0,8$ & laag & $-0,9$ & laag \\
-4.500 & $-0,8$ & laag & $-1,3$ & erg laag \\
-400 & $-0,8$ & laag & $-0,6$ & laag \\
-700 & $-0,8$ & laag & $-0,6$ & laag \\
-5.000 & $-0,8$ & laag & $-2,4$ & erg laag \\
-2.000 & $-0,8$ & laag & $-1,7$ & erg laag \\
-3.800 & $-0,7$ & laag & $-0,2$ & gemiddeld
\end{tabular}




\section{De aansluiting tussen onderwijs en arbeidsmarkt}

In dit boofdstuk zal een beeld worden geschetst van de aanshitingsproblematiek op de arbeidsmarkt. Eerst zal in paragraaf 3.1 worden ingegaan op verschillende aspecten van de actuele aansluitingsproblematiek op de arbeidsmarkt. Vanwege bet grote aantal onderscheiden opleidingstypen zal geen integraal beeld worden geschetst van alle opleidingstypen. In plaats daarvan zal de aansluitingsproblematiek van 24 min of meer representatieve opleidingstypen worden belicht. Daarna wordt in paragraaf 3.2 ingegaan op de conjuncturgevoeligheid van de werkgelegenheid in relatie tot de uitwijkmogelijkbeden op de arbeidsmarkt. Vervolgens zal in paragraaf 3.3 worden ingegaan op de verwachte arbeidsmarktperspectieven voor nieuwkomers. Daarbij worden in het bijzonder de opleidingstypen met zeer goede perspectieven en de opleidingstypen met slechte arbeidsmarktperspectieven nader belicht. Ten slotte wordt in paragraaf 3.4 een overzicht gegeven van de verwachte toekomstige knelpunten in de personeelsvoorziening, waarbij ook zal worden ingegaan op de bedriffsectoren die naar verwachting geconfronteerd zullen worden met zeer grote knelpunten in de personeelsvoorziening voor bepaalde opleidingstypen.

\subsection{Huidige aansluitingsproblemen}

Aansluitingsproblemen op de arbeidsmarkt kunnen zich op verschillende wijze manifesteren. Het werkloosheidspercentage voor een bepaald opleidingstype geeft een indicatie van de 'open discrepanties' tussen vraag en aanbod op de arbeidsmarkt. Naast deze open discrepanties kan er ook sprake zijn van 'verborgen discrepanties' bij degenen die wel emplooi hebben gevonden. Daarvan is bijvoorbeeld sprake als schoolverlaters door het aanbodoverschot van arbeidskrachten met hun opleidingsachtergrond noodgedwongen werk accepteren beneden hun niveau, slechter beloond worden, vaker een tijdelijke in plaats van een vaste aanstelling krijgen, of vaker genoegen mosten nemen met part-time werk, terwijl men liever een full-time betrekking zou willen hebben.

In deze paragraaf zal de actuele arbeidsmarktsituatie aan de hand van de beschiklare informatie uit de grootschalige schoolverlatersonderzoeken met betrekking tot het $\mathrm{VBO}, \mathrm{AVO}, \mathrm{MBO}, \mathrm{HBO}$ en het WO economie in beeld worden gebracht ${ }^{\text {. Vanwege het }}$ grote aantal onderscheiden opleidingstypen zal geen integraal overzicht worden gegeven voor alle onderscheiden opleidingstypen. Dergelijke overzichten zijn te vinden in deel 3 van de Statistische Bijlage. In plaats daarvan zullen de verschillende aspecten van de actuele aansluitingsproblematiek in beeld worden gebracht voor 24 opleidingstypen. Daarbij is getracht zo goed mogelijk alle opleidingsniveaus en -richtingen, watrvoor schoolverlatersonderzoek beschikbaar is, in het overzicht te betrekken. Tabel 3.1 geeft

8 Deze schoolverlatersinformatie is achtereenvolgens afkomstig uit de RLBSS-enquete, de IIBOMonitor en WO-monitor economie. Een uitvoerige rapportage van de resultaten van dere sehorlverlaters-onderzoeken is te vinden in ROA, Schoolverlaters IIrssen onderwijs en arbeidsmarkt 1906 , ROA-R-1997/3. Maastricht, 1997 en G.W.M. Ramaekers, WO-monitor economic /906, ROA-R. $1997 / 4$, Maastricht, 1997. 
een overzicht van de onderscheiden opleidingstypen, waarvoor in deze paragraaf de huidige aansluitingsproblemen op de arbeidsmarkt in beeld worden gebracht, met de bijhehorende nummers die in de onderstaande figuren gehanteerd worden om deze opleidingen aan te duiden.

\section{Tabel 3.1}

Overzicht van de onderscheiden opleidingstypen (met de bijbehorende nummers).

\section{Opleidingstype}

nummer

VBO bouwtechniek

VBO horeca en levensmiddelentechniek

VBO administratie, handel en textiel

VBO verzorging

HAVONWO

MBO landbouw en veeteelt

MBO installatietechniek

MBO grafische techniek

MBO procestechniek

MBO dokters-, tandarts- en dierenartsassistent

$\mathrm{MBO}$ verpleging

$\mathrm{MBO}$ uiterlijke verzorging

MBO toerisme en recreatie

HBO lerarenopleiding basisonderwijs

HBO milieukunde en levensmiddelentechnologie

HBO bouwkunde

HBO informatica

HBO chemische technologie

$\mathrm{HBO}$ verpleegkunde

HBO accountancy en bedriffseconomie

HBO maatschappelijk werk en hulpverlening

HBO uitvoerende en beeldende kunsten

Wo econom(etr)ie

WO accountancy en belastingen

Tabel 3.2

Werkloze beroepsbevolking naar opleidingsniveau, 1996

\section{Opleidingsniveau}

WO

Bron: CBS

Dalap voorutlopend geeft tabel 3.2 een overzicht van het werkloosheidspercentage nalar opleidingsniveau. U lit de tabel blijkt duidelijk dat de werkloosheidsproblematiek bij de lager opgeleiden aanzienlijk groter is dan bij de middelbaar en hoger opgeleiden. Met name onder degenen die alleen basisonderwijs hebben gevolgd is de werkloosheid 
erg hoog. Figuur 3.1 laat overigens zien dat vanaf 1994 het werkloosheidspercentage, na een aanvankelijke stijging in de eerste jaren van de jaren negentig, op alle opleidingsniveaus afneemt. Opmerkelijk is daarbij vooral dat de werkloosheid onder universitair opgeleiden de laatste jaren weer onder het werkloosheidsniveau van degenen met een $\mathrm{MBO} / \mathrm{LLW}$-niveau-opleiding is komen te liggen. Ook tussen de verschillende opleidingstypen zal de ernst van de werkloosheidsproblematiek waarschijnlijk sterk verschillen. Voor de beroepsbevolking als totaal zijn er echter slechts beperkte werkloosheidsciffers verbijzonderd naar opleidingstype, beschikbaar.

Figuur 3.1

Ontwikkeling van de werkloze beroepsbevolking naar opleidingsniveau, 1990-1996

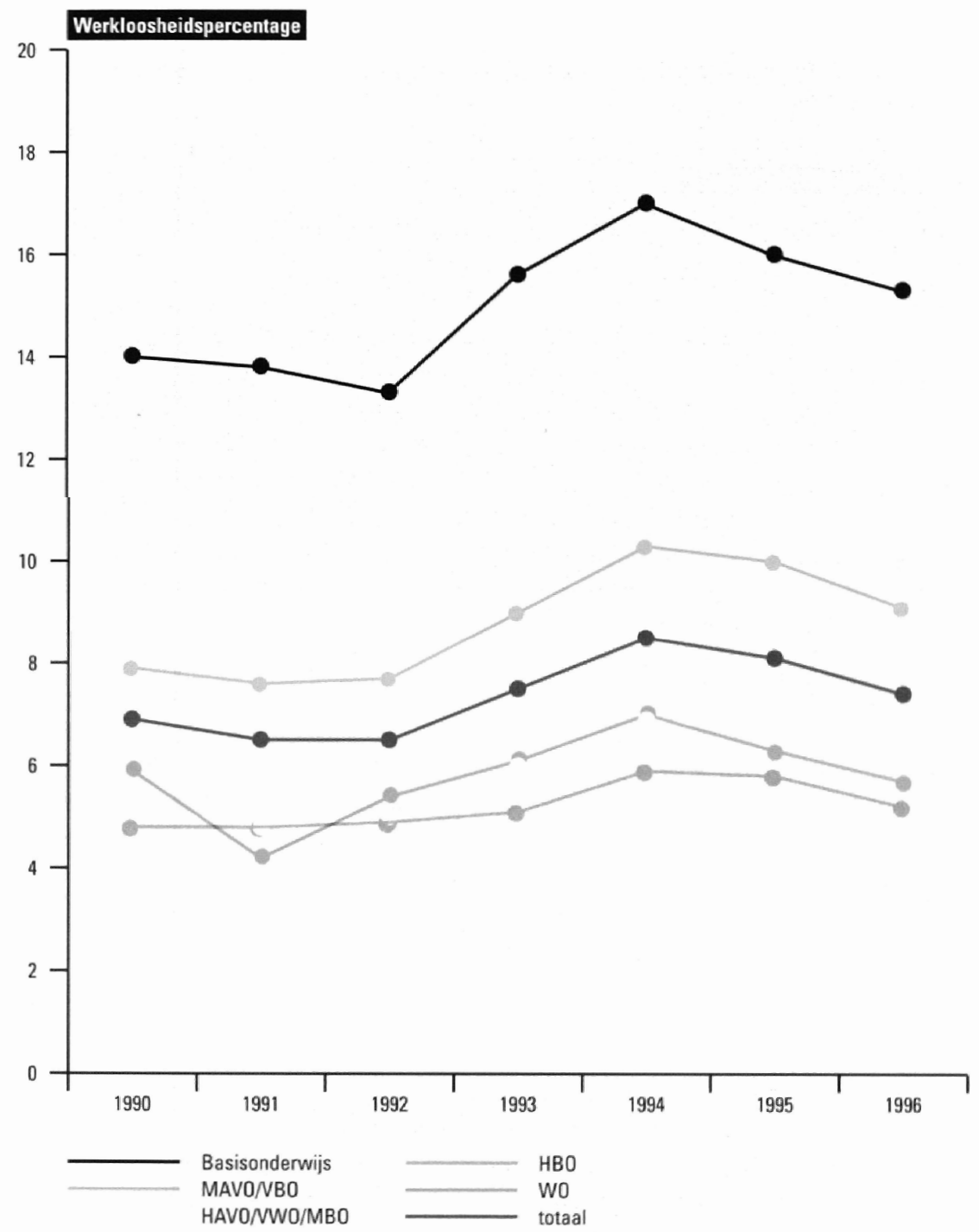


Uit de beschikbare schoolverlatersinformatie blijkt dat er tussen de opleidingstypen grote verschillen bestaan in de mate waarin het aanbod van schoolverlaters aansluit op de vraag op de arbeidsmarkt. Figuur 3.2 brengt dit in beeld, waarbij een onderscheid wordt gemaakt tussen de 'open discrepanties' in de zin van werkloosheid en 'verborgen discrepanties' voor zover die betrekking hebben op het werken in functies beneden het gevolgde opleidingsniveau. De figuur is in vier vakken ingedeeld. Op de horizontale as is het werkloosheidspercentage van de schoolverlaters afgebeeld en op de verticale as de mate van onderbenutting ${ }^{9}$ van het opleidingsniveau dat men heeft gevolgd. De horizontale en verticale lijn in de figuur geven respectievelijk de gemiddelde onderbenutting en het gemiddelde werkloosheidpercentage aan van alle in de schoolverlatersonderzoeken onderscheiden opleidingstypen.

Figuur 3.2

De huidige aansluitingsproblematiek van 24 opleidingstypen op basis van werkloosheid en onderbenutting, 1996*

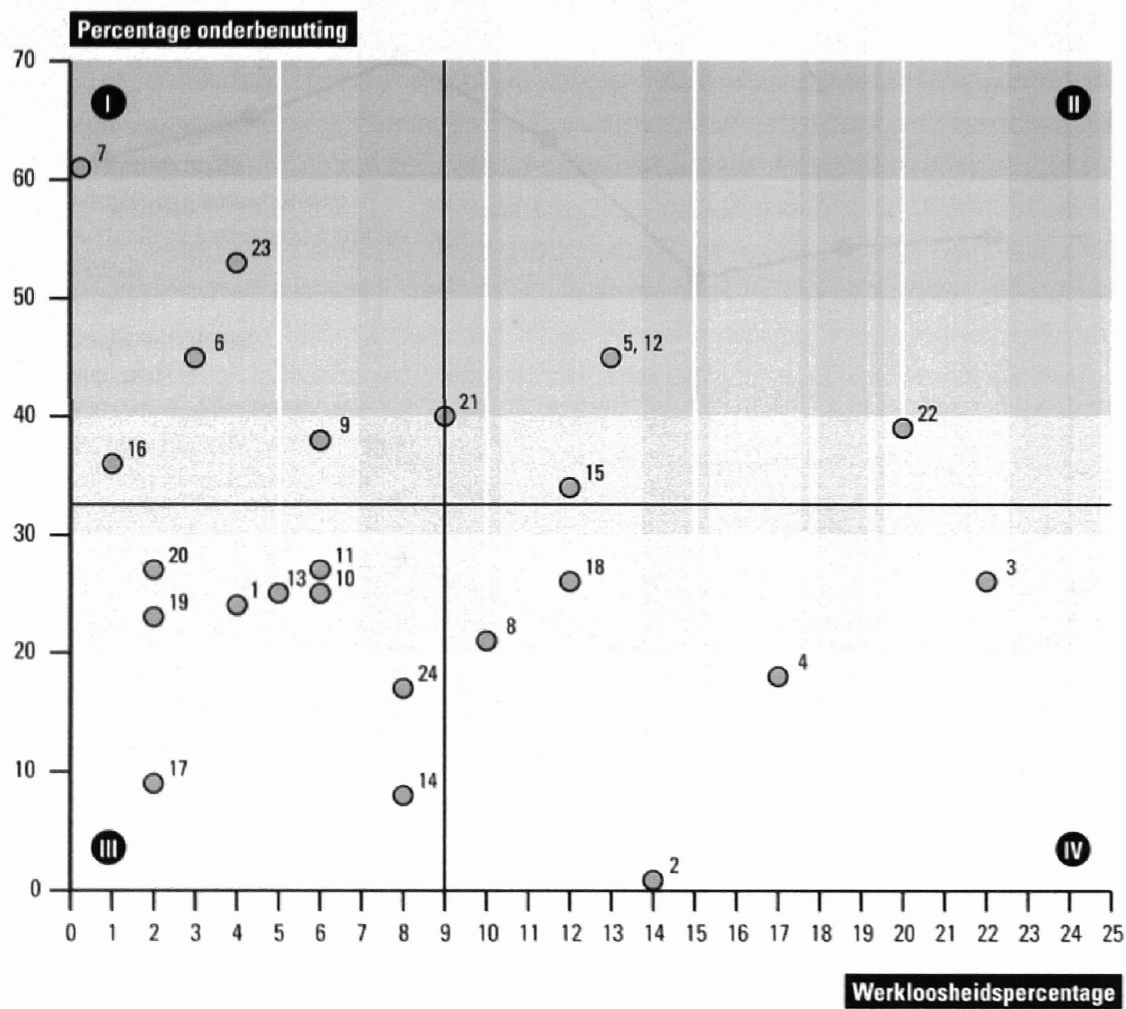

* tabel 3.1 geeft een overzicht van de onderscheiden opleidingstypen met de bijbehorende nummers.

Bron: ROA (schoolverlatersenquêtes RUBS, HBO-Monitor, WO-economie scanner)

9) Onderbenutting is een indicatie van de mate watarin arbeidskrachten werkzaam zijn op een functieniveau dat liger is dan hun opleidingsniveau. Deze matstaf komt tot stand door arbeidskrachten zelf te laten a angeven welk opleidingsniveau vereist is voor de door hen uitgeoefende functie. 
De aansluitingsproblematiek is het ernstigst bij de opleidingen in vak II. Bij deze opleidingen uiten de aanbodoverschotten zich zowel in een relatief hoge werkloosheid, als in een hoog percentage schoolverlaters dat werk heeft beneden het eigen opleidingsniveau. Uit de figuur blijkt dat de aansluitingsproblemen wat dit betreft het grootst zijn bij de opleidingstypen $H A V O / V W O, M B O$ uiterlijke verzorging en $H B O$ uitvoerende en beeldende kunsten. Ook bij de twee HBO opleidingen milieukunde en levensmiddelentechnologie en maatschappelijk werk en bulpverlening is er sprake van een hoge werkloosheid in combinatie met een hoge graad van onderbenutting.

Bij andere opleidingstypen is er sprake van een hoge werkloosheid onder de schoolverlaters in combinatie met een relatief geringe onderbenutting (vak IV). Het gaat hier om de VBO-opleidingen boreca en levensmiddelentechniek, administratie, handel en textiel en verzorging, MBO grafische techniek en $H B O$ chemische technologie. Bij deze opleidingstypen is de werkloosheid waarschijnlijk mede zo hoog omdat de werkzoekende schoolverlaters weinig of geen mogelijkheden hebben om werk te vinden in beroepen op een lager functieniveau, of omdat het aantrekkelijker is te wachten met het accepteren van een baan totdat zich een mogelijkheid voordoet om een baan te krijgen in een bij de opleiding aansluitende vakspecifieke functie.

Bij 5 van de 24 onderscheiden opleidingstypen spitst de huidige aansluitingsproblematiek op de arbeidsmarkt zich toe op de onderbenutting van het gevolgde opleidingsniveau (vak I). Dit is zowel het geval bij een drietal MBO-richtingen als bij twee hogere opleidingen. Schoolverlaters met als opleidingsachtergrond $M B O$ landbouw en veeteell, MBO installatietechniek en MBO procestechniek blijken, wanneer er onvoldoende vraag is in het beter bij de opleiding aansluitende beroependomein, goed in staat uit te wijken naar lagere functies op VBO-niveau. Schoolverlaters van de hogere opleidingen HBO bouw en WO econom(etr)ie kunnen daarentegen relatief gemakkelijk uitwijken naar lagere functies op MBO-niveau. Zoals gezegd, manifesteert de aansluitingsproblematiek bij deze opleidingstypen zich derhalve in de onderbenutting van het gevolgde opleidingsnivealu.

Bij de opleidingstypen in vak III is de huidige arbeidsmarktsituatie rooskleurig. Bij deze opleidingen is er sprake van een lage werkloosheid, terwijl bovendien slechts een gering aantal schoolverlaters genoegen moet nemen met een functie beneden het behaalde opleidingsniveau. Deze gunstige arbeidsmarktsituatie doet zich voor bij 9 van de 24 onderwijstypen. De hogere opleidingstypen zijn in vak III oververtegenwoordigd. Maar liefst 5 van de 9 onderwijstypen met een lage werkloosheid en weinig uitwijk naar lagere functies zijn HBO- of WO-opleidingen. Verder valt op dat het opleidingstype HBO informatica op de beide hier onderscheiden arbeidsmarktpositie-dimensies goed scoort: zowel het werkloosheids- als het onderbenuttingspercentage van deze opleiding is erg laag. De vier opleidingstypen op VBO- of MBO-niveau hebben allemaal een onderbenuttingspercentage van rond de $25 \%$. Het gat hier om de opleidingstypen VBO bountechniek, MBO toerisme en recreatie, MBO dokters-, tandarts-en dierenartsassistent en $M B O$ verpleging. Bij de hogere opleidingstypen is op dit punt sprake van cen veel grotere spreiding: het onderbenuttingspercentage loopt hier namelijk uiteen van $9 \%$ (HBO informatica) tot $27 \%$ (HBO accountancy en bedriffseconomie).

In figuur 3.3 wordt de actuele arbeidsmarktsituatie van de verschillende opleidingstypen vanuit meerdere invalshoeken in beeld gebracht. Daarbij is gekeken naar: 
- het percentage schoolverlaters dat werk heeft;

- het percentage schoolverlaters dat binnen drie maanden een baan heeft gevonden;

- het gemiddeld inkomen;

- de mate waarin een functie wordt uitgeoefend op het niveau van de gevolgde opleiding;

- het percentage werkenden waarvan de functie aansluit bij de richting van de gevolgde opleiding;

- het percentage werkenden met een vaste baan;

- het percentage werkenden met een full-time baan.

In de figuur wordt achtereenvolgens een beeld gegeven van de vier opleidingstypen die in figuur 3.2 naar voren komen als opleidingen met grote aansluitingsproblemen (vak II), negen opleidingstypen met weinig aansluitingsproblemen (vak III) en elf opleidingstypen die min of meer een tussenpositie innemen (vak I en IV). In zogenaamde heptagrammen is met behulp van twee omlijnende zevenvlakken een kwalitatieve typering van de onderscheiden arbeidsmarktkenmerken aangegeven. De indicatoren zijn zo gekozen dat een hoge waarde in principe gunstig is. Hierdoor is de arbeidsmarktpositie van de schoolverlaters met een bepaalde opleidingsachtergrond gunstiger, naarmate het oppervlak van het gearceerde vlak voor de desbetreffende opleiding groter is. Daarbij wordt in de figuur onderscheid gemaakt tussen 'relatief ongunstig' (tussen het middelpunt van de figuur en de bovenste lijn), 'gemiddeld' (tussen de twee lijnen) en 'relatief gunstig' (boven de bovenste lijn) ${ }^{10}$. Zo is bijvoorbeeld de kans op werk voor schoolverlaters van HBO uitwoerende en beeldende kunsten (22) met $80 \%$, in vergelijking met het gemiddelde van 91\% laag, waardoor de score bij 'kans op werk' onder de grens van 'gemiddeld' en 'relatief ongunstig' valt.

Voor het percentage schoolverlaters dat op het moment van enquêteren werk heeft gevonden en voor het percentage dat binnen drie maanden werk heeft gevonden is het zonder meer duidelijk dat een hoge score een goede arbeidsmarktpositie impliceert. Ook een hoog inkomen, een vaste baan en een baan die qua niveau of richting aansluit bij de gevolgde opleiding zal doorgaans als positief worden ervaren. Voor het percentage werkenden met een full-time baan is het echter minder evident dat dit een gunstige situatie betreft. Schoolverlaters kunnen immers zowel een part-time als een full-time baan ambiëren. Het lijkt er echter op dat schoolverlaters cloorgaans aanvankelijk een full-time baan zoeken. Bovendien blijkt uit onderzoek dat als de arbeidsmarktperspectieven ongunstiger worden, meer schoolverlaters part-time in plaats van full-time werk kriigen".

Uit figutr 3.3 blijkt duidelijk dat schoolverlaters van opleidingstypen waarbij sprake is van een hoge werkloosheid en een hoge mate van onderbenutting (vak II in figuur 3.2) ook te maken hebben met andere aansluitingsproblemen. Zo is bijvoorbeeld voor

10 De kwalitatieve typeringen zijn lepatald op basis van het gemidelele en de standaardafwijking van hed destedreffende artedidsmatitienmerk over alle onderscheiden opleidingen. Bij het verdiende inkomen is alleen uitgegaan van de opledingen op het destetreffende opleidingsniveatu (zie M.H

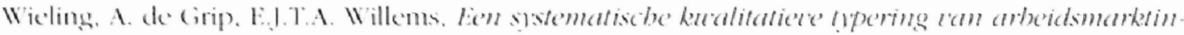
formatic. ROA-1W-1900 S, Maastricht, 1900)

11 Zie M.W. Wieling en L. Borghans, Aansluitingsproblemen en alanpassingsprocesien op de arbeids

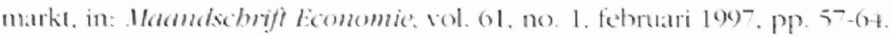


HAVO- en VWO'ers (5) het inkomen laag. Het is opmerkelijk dat er op één vlak wel goed wordt gescoord: het blijkt dat schoolverlaters van HAVO en VWO in het algemeen niet erg lang hoeven te zoeken naar een baan. Gezien het relatief hoge werkloosheidspercentage is er daarbij vaak sprake van instabiele arbeidsrelaties. Het opleidingstype $M B O$ uiterlijke verzorging (12) neemt, zoals ook al uit figuur 3.2 kon worden opgemakt, wat betreft de aansluitingsproblematiek zoals die tot uitdrukking komt in het werkloosheids- en onderbenuttingspercentage, een vergelijkbare positie in als het opleidingstype $H A V O / V W O$. Wat betreft de andere aspecten staat MBO witerlijke verzorging er echter wat beter voor. De schoolverlaters met deze onderwijsachtergrond die wel werk weten te vinden, komen bijvoorbeeld erg vaak in vaste banen terecht.

Aansluitingsproblemen blijven niet beperkt tot het lager en middelbaar onderwijs. Ook schoolverlaters van een tweetal opleidingstypen uit het $\mathrm{HBO}$ ervaren problemen bij de overgang van school naar werk. Bij het opleidingstype HBO milieukunde en levensmiddelentechnologie (15) komen de aansluitingsproblemen vooral tot uiting in de lage kans op werk. Daarnaast moet over het algemeen vrij lang naar een baan gezocht worden en hebben relatief weinig schoolverlaters een vaste aanstelling. De andere opleiding op hoger niveau waarbij aansluiting tussen opleiding en arbeidsmarkt problematisch is, is de opleiding HBO uitwoerende en beeldende kunsten (22). Het gaat hier dan vooral om de eerder genoemde 'open discrepanties' die tot uitdrukking komen in erg lage kansen op werk en een lange zoekduur naar een baan.

Opleidingen met weinig aansluitingsproblemen worden in het tweede gedeelte van figuur 3.3 gepresenteerd. Het valt op dat alle opleidingsniveaus vertegenwoordigd zijn, iets dat wellicht te rijmen valt met de goede staat waarin de Nederlandse economie zich

Figuur 3.3

Overzicht van verschillende aspecten van de arbeidsmarktpositie van schoolverlaters van 24 opleidingstypen, 1996

\section{Veel aansluitingsproblemen}

\section{HAVONWO}

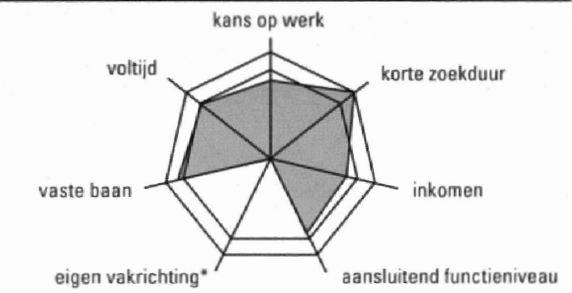

HBO milieukunde en levensmiddelentechnologie

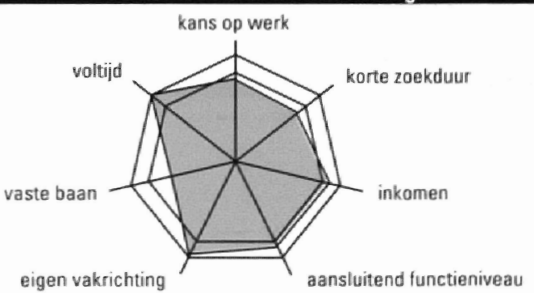

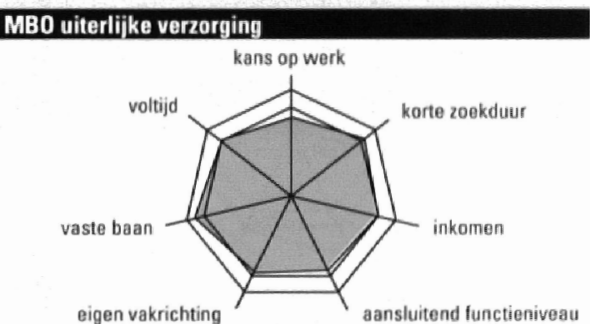

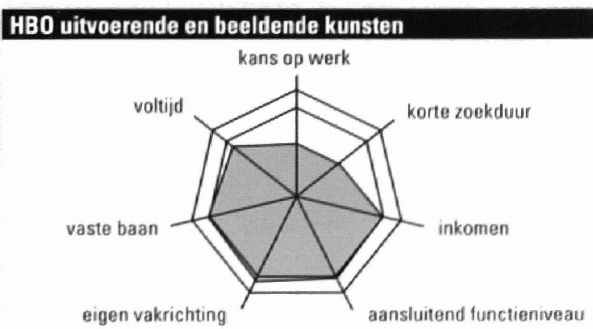

- Voor het HAVO/WW wordt, gezien het algemene karakter van de opleiding, niet gevraagd of de functie aanshuit bij de eigen vakrichting. 
Figuur 3.3 (vervolg)

Overzicht van verschillende aspecten van de arbeidsmarktpositie van schoolverlaters van 24 opleidingstypen, 1996
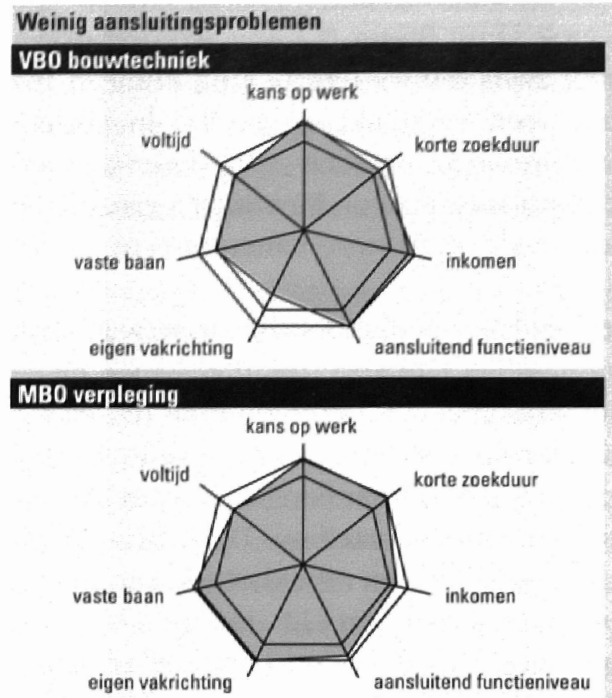

HBO lerarenopleiding basisonderwijs

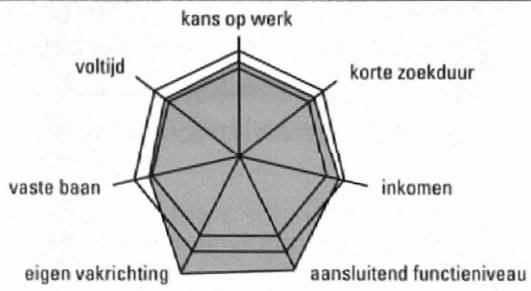

\section{HBO verpleegkuade}

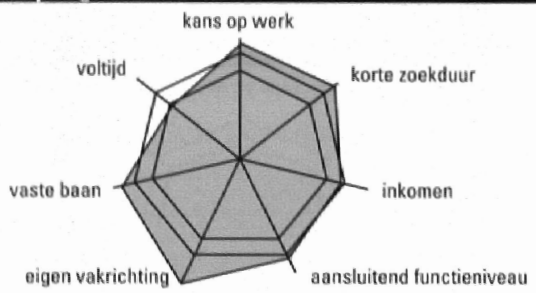

Wo accountancy en belastingen

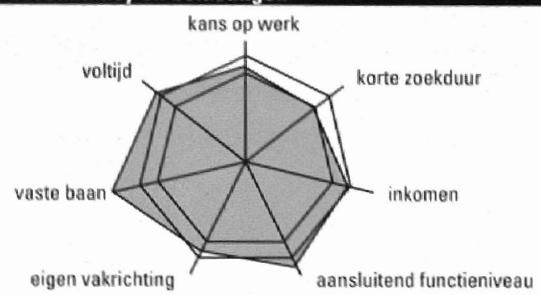

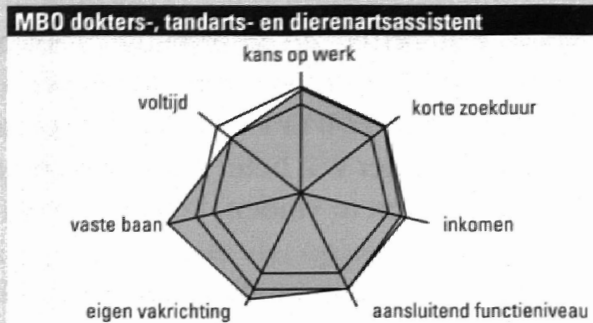

\section{MBO toerisme en recreatie}

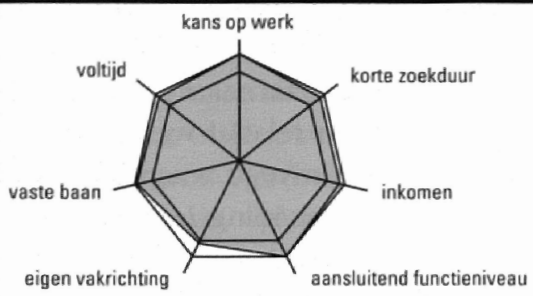

\section{HBO informatica}

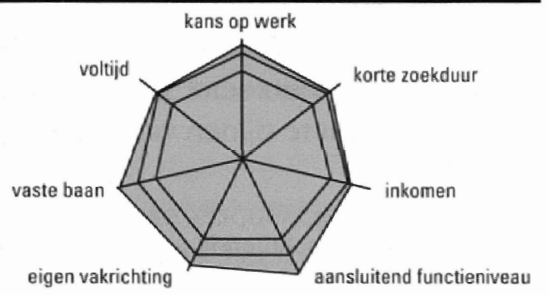

HBO accountancy en bedrifiseconomie

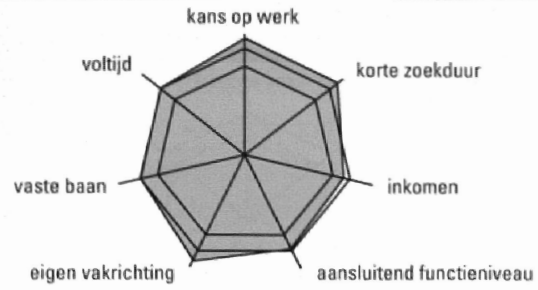




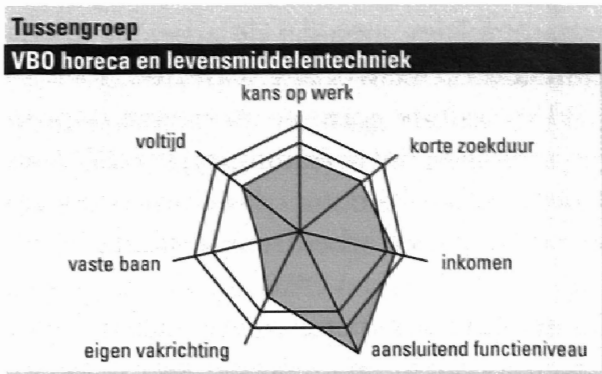

\section{VBO verzorging}

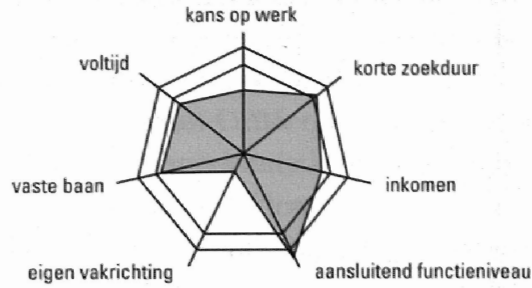

MBO installatietechniek

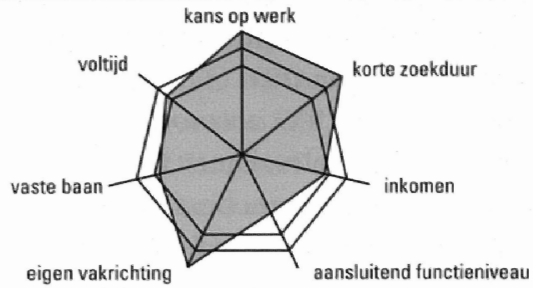

MB0 procestechniek

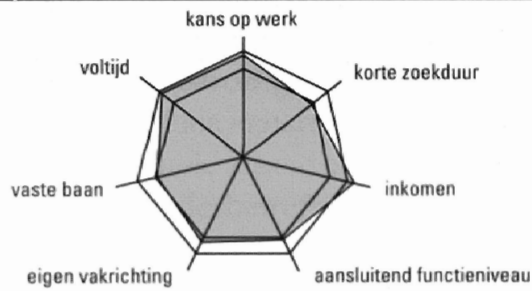

\section{HBO chemische technologie}
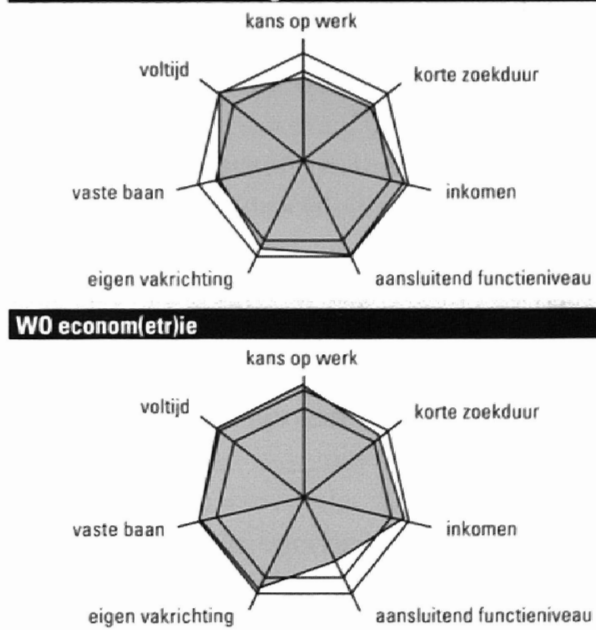

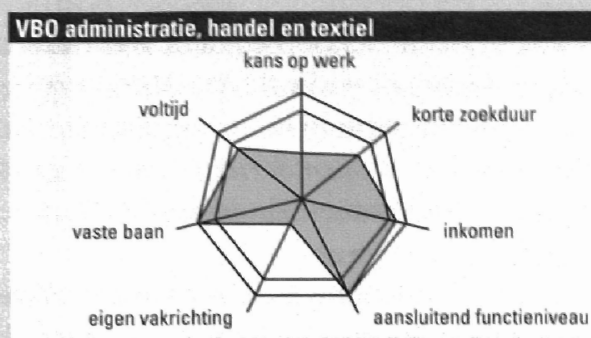

MBO landhouw en veeteelt

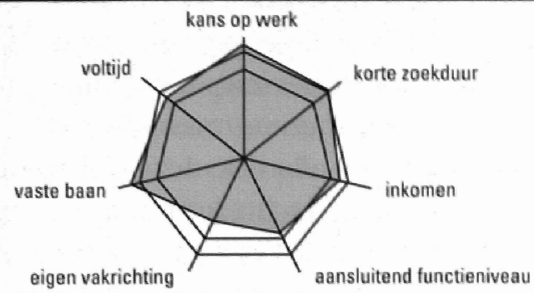

MB0 grafische techniek

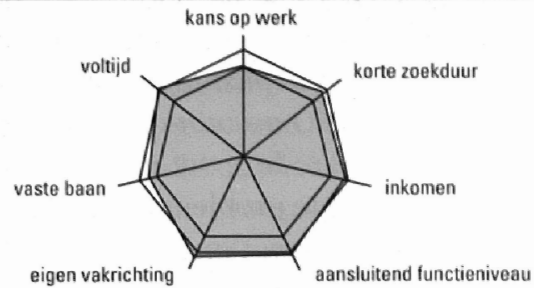

\section{HBO bouwkunde}

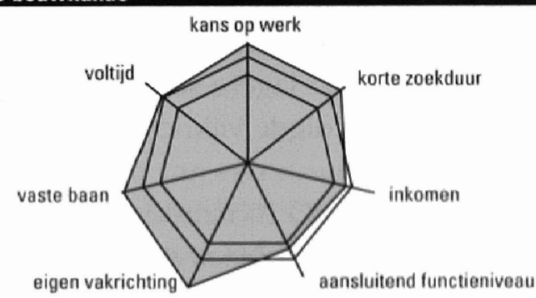

\section{HBO maatschappelijk werk en hulpverlening}

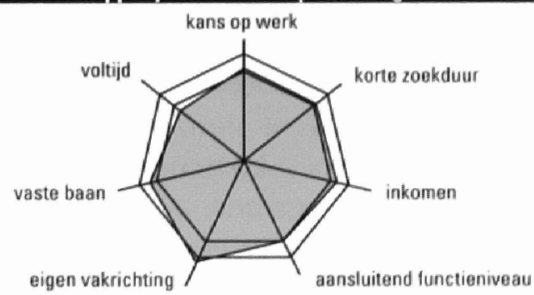


momenteel bevindt. De verschillende heptagrammen laten zien dat de arbeidsmarktsituatie voor de schoolverlaters van deze opleidingen op vrijwel alle aspecten goed is. Alleen bij het opleidingstype $M B O$ verpleging (11) wordt de gunstige arbeidsmarktpositie niet weerspiegeld in het verdiende inkomen, terwijl bij het opleidingstype HBO lerarenopleiding basisonderwijs (14) het geringe aantal schoolverlaters dat een vaste baan heeft gevonden niet lijkt te corresponderen met de gunstige arbeidsmarktsituatie.

De schoolverlaters van VBO bouwtechniek (1) ervaren met name weinig aansluitingsproblemen doordat er sprake is van een lage werkloosheid en er slechts kort naar een baan hoeft te worden gezocht. Bovendien is het inkomen relatief hoog en wordt de functie veelal uitgeoefend op het niveau van de gevolgde opleiding. Op middelbaar niveau zijn er weinig aansluitingsproblemen bij de opleidingstypen $M B O$ dokters-, tandarts-en dierenartsassistent (10), MBO verpleging (11) en $M B O$ toerisme en recreatie (13). Voor alle drie deze opleidingen geldt dat de werkloosheid onder schoolverlaters laag is, er slechts kort naar een baan hoeft te worden gezocht en het aandeel van schoolverlaters dat een vaste aanstelling heeft hoog is. Ook heeft men meestal een baan die aansluit op het niveau van de gevolgde opleiding.

De opleidingstypen op hoger niveau warbij weinig aansluitingsproblemen voorkomen zijn HBO lerarenopleiding basisonderwijs (14), HBO informatica (17), HBO verpleegkunde (19), HBO accountancy en bedriffseconomie (20) en WO accountancy en belastingen (24). Van deze vijf opleidingstypen hebben de schoolverlaters van $H B O$ informatica de minste problemen, omdat dit opleidingstype erg hoog scoort op alle in figuur 3.3 onderscheiden dimensies. De HBO lerarenopleiding basisonderwijs valt, zoals gezegd, op doordat schoolverlaters van dit opleidingstype vaker geen vaste baan krijgen dan schoolverlaters van de andere vier hogere opleidingen waarbij weinig aansluitingsproblemen voorkomen. Schoolverlaters van WO accountancy en belastingen (24) hebben een wat lagere score wat betreft de mate waarin het werk dat men heeft aansluit bij de gevolgde vakrichting en de mate waarin schoolverlaters snel een baan hebhen gevonden.

De opleidingen in het latste gedeelte van figuur 3.3 nemen een tussenpositie in wat betreft de actuele arbeidsmarktsituatie in de zin dat de aansluitingsproblematick zich met name manifesteert in een hoog werkloosheidspercentage onder schoolverlaters of voral in een skechte aansluting van het functieniveatu watop men werk vindt en het niveau van de gevolgde opleiding.

In de tussengroep komen drie VBO-opleidingen voor: boreca en levensmiddelentechnick (2), administratie, bandel en textid (3) en verzorging (4). Voonal het opleidingsIype 1 'BO administratie, handel en textiel heeft te kampen met een erg hoge werkloosheid. Voor alle drie genoemde opleidingen geldt dat de atansluiting tussen de functie die men heeft en de gevolgde opleidingsrichting slecht is. Bij VBO horeca en levensmiddelentechniek en $V B O$ verzorging hebben bovendien relatief weinig schoolverlaters een vaste haan. Bij het latstgenoemde opleidingstype is ook het verdiende inkomen relaticitarg.

Opleidingstypen met een erg lage werkloosheid mar met een hoge mate van onder-

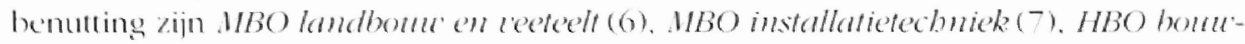


kunde (16) en WO econom(etr)ie(23). Naast het hoge onderbenuttingspercentage hebben schoolverlaters van MBO landbouw en veeteelt ook te maken met een slechte aansluiting tussen de richting van de gevolgde opleiding en de functie die uitgeoefend wordt. Dat laatste is bij $M B O$ installatietechniek niet het geval. Hier is de arbeidsmarktpositie zwakker op andere punten. Niet alleen is er sprake van van een relatief laag inkomen, ook heeft men vaak geen vaste baan. Bij de twee opleidingstypen uit het hoger onderwijs, HBO bouwkunde en WO econom(etr)ie, uit het aansluitingsprobleem zich slechts op één vlak. Beide opleidingstypen hebben te kampen met een hoge graad van onderbenutting.

Bij drie opleidingstypen in de tussengroep zijn de verschillen in de actuele aansluitingsproblematiek met de opleidingstypen in vak II, waarbij er sprake is van zowel een hoge werkloosheid als een hoge graad van onderbenutting niet groot. Wel is éen van de twee percentages niet hoog genoeg om ervoor te zorgen dat die opleidingstypen net onder de groep opleidingen met veel aansluitingsproblemen (vak II in figuur 3.2) vallen. Het betreft hier de opleidingstypen $M B O$ grafische techniek (8), MBO procestechniek (9) en HBO chemische technologie (18). Van deze drie opleidingen heeft de latatgenoemde het hoogste werkloosheidspercentage. Ook doen de schoolverlaters van $H B O$ chemische technologie er langer dan gemiddeld over om een baan te zoeken. Schoolverlaters van MBO grafische techniek hebben een lage kans op werk, terwijl voor de andere dimensies uit figuur 3.3 ongeveer gemiddeld gescoord wordt. Schoolverlatende MBO'ers met afstudeerrichting procestechniek hebben weliswaar een wat lagere werkloosheid en een relatief hoog inkomen, maar worden vooral geconfronteerd met een slechte aansluiting tussen het niveau van de uitgeoefende functie en het niveau van de opleiding. Daarnaast is het aandeel werkzame schoolverlaters met een vaste aanstelling laag.

\subsection{Conjunctuurgevoeligheid en uitwijkmogelijkheden}

Een slechte actuele arbeidsmarktsituatie kan het gevolg zijn van een structureel awakke positie van het desbetreffende opleidingstype op de arbeidsmarkt. Omgekeerd hexti echter een opleiding met een structureel zwakke positie niet doorlopend med a ansluitingsproblemen geconfronteerd te worden. Als bijworbeeld de werkgelegenheid voor een bepaald opleidingstype erg conjunctuurgevoelig is, kan de arbeidsmarktsituatic tijdelijk gunstig zijn omdat er sprake is van een hoogconjuncture. Om een beter beeld te kunnen krijgen van de mogelijke kwetshatrheid van de verschillende opleidingstypen, wordt in deze paragraaf ingegaan op de min of meer structurele kenmerken van cle arbeidsmarktpositie, die een indicatie geven van de arbeidsmarktrisico's die de keuze voor een bepatalde opleiding met zich meebrengt

In de eerste plaats komt het arbeidsmarktrisico van een bepalde opleidingskeuze tor uiting in de mate watain de werkgelegenheid van degenen met de desbetreffende opleidingsachtergrond onderhevig is a an conjuncturele fluctuaties. Wanneer er sterke schommelingen optreden in de werkgelegenheid voor een bepald opleidingstype, is er voor degenen die voor deze opleiding kiezen op het moment dat het economisch tij gunstig is een risico dat hun arbeidsmarktperspectieven op het moment dat zij hun diploma behalen slecht zijn. ondat de economie dan misschien net in een dal zit. Bovendien is er in dat geval sprake van een onzekere werkgelegenheidssituatic op lan- 
gere termijn, vanwege de grotere kans op toekomstig baanverlies als er op een gegeven moment weer sprake is van een laagconjunctuur.

De risico's op de arbeidsmarkt beperken zich vanzelfsprekend niet tot de conjuncturele fluctuaties in de werkgelegenheid. Ook de mate waarin schoolverlaters afhankelijk zijn van de werkgelegenheidsperspectieven in slechts een beperkt aantal beroepen of bedrijfssectoren is een belangrijke risicofactor. Dit risico is vooral groot bij opleidingen die specifiek gericht zijn op functies in een bepaalde vakdeelmarkt. Degenen die daarentegen een opleiding hebben gevolgd waarmee men in diverse beroepen en bedrijfssectoren emplooi kan vinden, kunnen als het werkgelegenheidsperspectief in een bepaalde beroepsgroep minder gunstig is, betrekkelijk gemakkelijk uitwijken naar beroepen waarvoor de werkgelegenheidsontwikkeling gunstiger is. Bovendien zijn degenen die voor deze opleidingen hebben gekozen ook meer flexibel op de arbeidsmarkt wanneer men tijdens de studie- of arbeidsloopbaan meer inzicht krijgt in de persoonlijke capaciteiten en voorkeuren die men heeft, waardoor de beroepsperspectieven die aanvankelijk aanlokkelijk leken, hun aantrekkingskracht verliezen.

Figuur 3.4

Arbeidsmarktrisico's voor schoolverlaters van 24 opleidingstypen op basis van conjunctuurgevoeligheid en beroepenspreiding, 1995-1996*

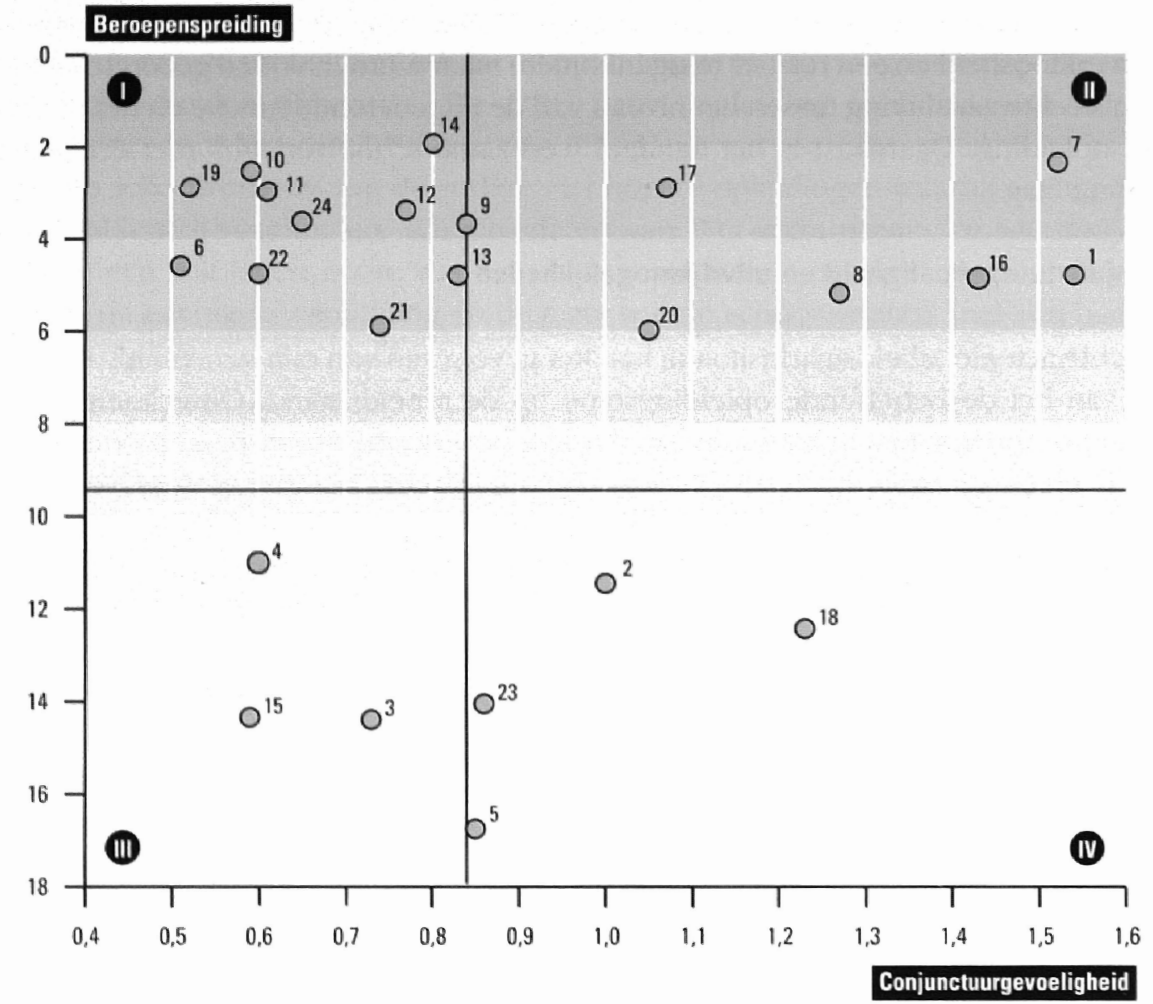

* Tabel 3.1 geeft een overzicht van de onderscheiden opleidingstypen met de bijbehorende nummers. Bronl: ROA 
Het volgen van een brede opleiding is overigens niet in alle gevallen positief. Wanneer er sprake is van veel uitwijkmogelijkheden impliceert dit immers ook dat de schoolverlaters op de arbeidsmarkt meer concurrentie zullen ondervinden van andere opleidingstypen. Bovendien kan een verbreding van een opleiding ten koste gaan van de specialisatie, waardoor de productiviteit c.q. de directe inzetbaarheid van de schoolverlaters geringer wordt. Het belang van uitwijkmogelijkheden op de arbeidsmarkt moet daarom vooral worden gezien in relatie tot het risico op een niet stabiele werkgelegenheidsontwikkeling.

Figuur 3.4 geeft een overzicht van de mate waarin de werkenden met een bepaalde opleidingsachtergrond geconfronteerd worden met de beide genoemde arbeidsmarktrisico's. Evenals in figuur 3.2 is er een indeling gemaakt in vier vakken. Vak II heeft betrekking op de opleidingstypen waarvoor de arbeidsmarktrisico's het grootst zijn. Bij deze opleidingstypen is er sprake van zowel een hoge conjunctuurgevoeligheid als een gering aantal uitwijkmogelijkheden naar beroepen op een aansluitend niveau.

Dit is het geval bij de opleidingstypen VBO bouwtechniek (1), MBO installatietechniek (7), MBO grafische techniek (8), MBO procestechniek (9), HBO bouwkunde (16), HBO informatica (17) en HBO accountancy en bedriffseconomie (20). VBO bouwtechniek. en $M B O$ installatietechniek zijn het meest conjunctuurgevoelig van deze groep. Het opleidingstype $H B O$ informatica heeft daarentegen erg weinig uitwijkmogelijkheden, omdat de scholing die men in deze opleiding krijgt slechts bruikbaar is in een klein aantal beroepsgroepen.

De positie van de 24 onderscheiden opleidingstypen in figuur 3.4 kunnen vergeleken worden met de onderbenuttingsgraad en het werkgelegenheidspercentage van schoolverlaters zoals die in figuur 3.2 ter sprake kwamen. Het blijkt dat er weinig verband bestaat tussen in figuur 3.2 onderscheiden vraag-aanbod discrepanties en de arbeidsmarktrisico's in figuur 3.4. Voor het opleidingstype HBO informatica (17) geldt bijvoorbeeld dat er weinig problemen zijn wat betreft de actuele positie op de arbeidsmarkt (zie figuur 3.2), maar dat de arbeidsmarktrisico's substanticel zijn. Voor IIBO) milieukunde en levensmiddelentechnologie (15) geth het omgekeerde. Werkenden met dit opleidingstype hebben goede uitwijkmogelijkheden en weinig last van schommelingen in de conjunctuur. Toch is de actuele situatie voor schoolverlaters van IIBO milienkunde en levensmiddelentechnologie niet zo rooskleurig. Het werkloosheidspercentage is hoog en de graad van onderbenutting is hoger dan gemiddeld. Kennelijk zijn bij dit opleidingstype de goede uitwijkmogelijkheden niet toereikend geweest om de $x^{\prime}$ aansluitingsproblemen te voorkomen.

De opleidingstypen in vak III worden nauwelijks geconfronteerd met beide arbeidsmarktrisicos. Er is sprake van zowel een lage conjunctuurgevoeligheid als een groot aantal uitwijkmogelijken naar beroepsgroepen warvan het functieniveau a ansluit bij het behaalde opleidingsniveau. Deze gunstige risico-positie doet zich voor bij VBO lerzorging (4), IBO administratie, handel en textiel (3) en IIBO milienkunde en levertsmiddelentechnologie (15).

Voor de overige opleidingstypen kan geen eenduidige uitspraak worden gedatan over de risico's die men met de desbetreffende opleidingsachtergrond in het algemeen op de. 
arbeidsmarkt loopt. Bij de opleidingstypen in vak I zijn de uitwijkmogelijkheden naar andere beroepen op een aansluitend functieniveau gering. Dit geringe uitwijkpotentieel zal doorgaans echter niet bezwaarlijk zijn, gezien de relatief stabiele werkgelegenheidsontwikkeling in het beroependomein van deze opleidingstypen. Het gaat hier uitsluitend om opleidingen op middelbaar of hoger niveau. Vijf MBO-opleidingen hebben een lage conjunctuurgevoeligheid in combinatie met weinig uitwijkmogelijkheden. Het gaat hier om de opleidingstypen $M B O$ landbouw en veeteelt (6), MBO dokters-, tandarts- en dierenartsassistent (10), MBO verpleging (11), MBO uiterlijke verzorging (12) en $M B O$ toerisme en recreatie (13). De vier HBO-opleidingstypen die weinig hinder ondervinden van conjunctuurschommelingen, maar moeilijk naar andere beroepen kunnen uitwijken zijn HBO leraren opleiding basisonderwijs (14), HBO verpleegkunde (19), HBO maatschappelijk werk en bulpverlening (21) en HBO uitvoerende en beeldende kunsten (22). Ten slotte is er ook bij WO accountancy en belastingen (24) sprake van een lage conjunctuurgevoeligheid van de werkgelegenheid in combinatie met een gering aantal uitwijkmogelijkheden.

De opleidingstypen in vak III hebben daarentegen te kampen met een sterk conjuncturgevoelige werkgelegenheidsontwikkeling. Wanneer de werkgelegenheidssituatie voor deze opleidingen op een bepaald moment echter ongunstig is, zal dit waarschijnlijk enigszins kunnen worden opgevangen doordat men betrekkelijk gemakkelijk kan uitwijken naar andere beroepen op een aansluitend niveau. Deze situatie doet zich voor bij de opleidingstypen VBO boreca en levensmiddelentechniek, (2) HAVO/VWO (5), HBO chemiscbe technologie (18) en WO econom(etr)ie (23). Van deze opleidingstypen komt $H A V O / V W O$ er het gunstigst van af: de uitwijkmogelijkheden zijn mede door het algemeen karakter van de opleiding het hoogst van alle in figuur 3.4 onderscheiden opleidingstypen, terwijl de conjunctuurgevoeligheid niet veel hoger is dan gemiddeld.

\subsection{Arbeidsmarktperspectieven voor schoolverlaters}

Zoals in figuur 1 werd aangegeven, kan op basis van de in hoofstuk 2 belichte vraagen aanbodontwikkelingen op de arbeidsmarkt een indicaltie worden gegeven van de verwachte arbeidsmarktperspectieven voor nieuwkomers op de arbeidsmarkt, verbijzonderd natar opleidingstype. De uitspraken op dit punt zijn gebaseerd op de Indicator Toekomstige Arbeidsmarktperspectieven (ITA) die voor elk opleidingstype de verhouding weergeeft tussen het arbeidsaanbod met de desbetreffende opleidingsachtergrond en de daar tegenoverstaande vraiag. Als het arbeidsaanbod kleiner is dan de vraig, en de ITA dus kleiner is dan 1,00, wordt de arbeidsmarkt als goed getypeerd. Als de waarde vin de ITA zelfs kleiner is dan 0,85 dan word gesproken van een zeer goed arbeidsmarktperspectief. Wanneer de ITA daarentegen een waarde heeft tussen de 1.00 en 1,05 en het aanbodoverschot niet veel groter is dan wat als frictie kan worden beschouwd. wordt gesproken van een redelijk arbeidsmarktperspectief. Bij een hogere waarde van de ITA wordt het arbeidsmarktperspectief voor het desbetreffende opleidingstype als matig, of als de ITA zelfs groter is dan 1,15, als slecht alangeduid.

\section{Opleidingen met zeer goede perspectieven}

De voor de periode 1997-2002 verwachte relatief gunstige arbeidsmarktontwikkelingen zullen er toe leiden dat voor een groot alantal opleidingstypen gunstige tot zeer gunstige 
arbeidsmarktperspectieven worden verwacht. In tabel 3.27 van de Statistische Bijlage wordt een integraal overzicht gegeven van de verwachte arbeidsmarktperspectieven voor in totaal 98 onderscheiden opleidingstypen. Voor maar liefst 74 van de 98 opleidingstypen wordt een goed of zeer goed arbeidsmarktperspectief verwacht. Met uitzondering van het laagste opleidingsniveau (alleen basisonderwijs) komen er op elk opleidingsniveau opleidingstypen voor met goede arbeidsmarktperspectieven. Zoals uit tabel 1.6 naar voren kwam, zijn er echter vooral in het hoger onderwijs veel opleidingstypen waarvoor goede tot zeer goede arbeidsmarktperspectieven worden verwacht. In feite is er bij de hoger opgeleiden vrijwel over de gehele linie sprake van goede arbeidsmarktperspectieven.

Tabel 3.3 geeft een overzicht van de opleidingstypen waarvoor de arbeidsmarktperspectieven zeer goed zijn. Uit de tabel blijkt dat de groep opleidingen met zeer goede perspectieven geen opleidingstypen op VBO-niveau of lager bevat. Het valt op dat verhoudingsgewijs in de hogere opleidingsniveaus de meeste opleidingstypen voorkomen met een zeer goed perspectief. Zo hebben op MBO/LLW-niveau vier van de 31 onderscheiden opleidingen een zeer goed perspectief. Op HBO-niveau, waarin totaal 33 opleidingstypen worden onderscheiden, bevat de groep met zeer goede perspectieven zes opleidingstypen. Op WO-niveau hebben zes van de 18 onderscheiden opleidingen een zeer goed perspectief.

Tabel 3.3

Opleidingstypen met zeer goede arbeidsmarktperspectieven in 2002

Opleidingstype

MBO/LLW, HAVO/VWO

MBO/LLW operationele techniek

YBO/LLW horeca

$\mathrm{HBO}$

$\mathrm{HBO}$ recht en bestuur

$\mathrm{HBO}$ vervoer en logistiek

HBO bouwkunde

HBO lerarenopleiding economie en maatschappij $\quad 0,85$

HBO landhouw en reeteel

HBO informatica

WO

WO accountancy en belastingen $\quad 0,67$

WO civiele techniek $\quad 0.73$

$\begin{array}{ll}\text { WO bouwkunde } & 0.78\end{array}$

$\begin{array}{lr}\text { WO informatica en bestuurlijke informatiekunde } & 0.78\end{array}$

$\begin{array}{ll}\text { Wo bedrijfskunde } & 0.78\end{array}$

wo tandheelkunde $\quad 0,81$

Bron: ROA 
De opleidingen met zeer goede perspectieven op MBO-niveau zijn niet geconcentreerd in een bepaalde richting. Zowel voor de technische opleidingstypen operationele techniek en procestechniek als voor de opleidingstypen verpleging en boreca is er sprake van zeer goede arbeidsmarktperspectieven. Bij deze opleidingen is vooral de uitbreidingsvraag verantwoordelijk voor de rooskleurige vooruitzichten. Deze opleidingen worden gekenmerkt door een relatief (erg) hoge uitbreidingsvraag, die in alle gevallen hoger is dan de vervangingsvraag. Daarnaast varieert de instroom van gemiddeld tot erg laag.

Ook op HBO-niveau is er bij sterk uiteenlopende opleidingstypen sprake van zeer goede arbeidsmarktperspectieven. De opleidingen op HBO-niveau vertonen wat minder samenhang dan de MBO-opleidingstypen wat betreft de achterliggende oorzaken van de zeer goede perspectieven. Bij de HBO lerarenopleiding economie en maatschappijen het opleidingstype HBO vervoer en logistiek is het de hoger dan gemiddelde vervangingsvraag in combinatie met de lage arbeidsmarktinstroom die ervoor zorgen dat dit opleidingstype een zeer goed perspectief heeft. Bij het opleidingstype $H B O$ landbouw en veeteelt is er sprake van een hoge arbeidsmarktinstroom, die wordt gecompenseerd door een (erg) hoge uitbreidings- en vervangingsvraag. Van een zelfde situatie is sprake bij het opleidingstype HBO bouwkunde. Ook hier kan de grote groep instromende schoolverlaters rekenen op meer dan voldoende baanopeningen.

Het opleidingstype $H B O$ informatica heeft zeer goede perspectieven doordat de uitbreidingsvraag erg hoog is. De vervangingsvraag naar HBO informatici is daarentegen laag omdat het hier een relatief jonge opleiding betreft. Voor het opleidingstype $H B O$ recht en bestuur wordt om dezelfde redenen een zeer goed perspectief verwacht. Ook is hier sprake van een erg lage arbeidsmarktinstroom, een gemiddekle vervangingsvraag en een hoge uitbreidingsvraag.

Tabel 3.4 geeft een overzicht van de opleidingstypen watrvoor ondanks de in het algemeen gunstige arbeidsmarktontwikkelingen de verwachte arbeidsmarktperspectieven slecht zijn. In totalal is dit voor slechts vijf opleidingstypen het geval.

Talbel 3.4

Opleidingstypen met slechte arbeidsmarktperspectieven in 2002

Opleidingstype

MAVO, VBO

VBO installatietechniek

$\checkmark B O$ administratie, handel en textiel

IBO horeca en levensmiddelentechniek

MBO/LLW, HAVO/VWO

$\mathrm{MBO} / \mathrm{LLW}$ toerisme en recreatie

$\mathrm{HBO}$

IIBO personeetswerk

Bron: ROA 
De opleidingstypen met slechte perspectieven zijn meestal opleidingen op lager of middelbaar niveau. Binnen het VBO zijn er drie opleidingstypen met slechte perspectieven. In het MBO heeft slechts één opleidingstype een slecht arbeidsmarktperspectief. Het opleidingstype VBO installatietechniek heeft een slecht perspectief doordat de arbeidsmarktinstroom erg hoog is. VBO boreca en levensmiddelentechniek en VBO administratie, handel en techniek daarentegen hebben slechte vooruitzichten als gevolg van een forse krimp van de vraag. Eerder in dit hoofdstuk bleek al dat schoolverlaters van VBO administratie, handel en techniek ook nu al te kampen hebben met een erg hoog werkloosheidspercentage.

De MBO-opleiding toerisme en recreatie kwam al ter sprake in het kader op bladzijde 28. Het erg hoge instroompercentage van schoolverlaters van meer dan $9 \%$ op jaarbasis en de erg lage vervangingsvraag zorgen ervoor dat voor dit opleidingstype de komende periode een slecht arbeidsmarktperspectief verwacht wordt. De HBO-opleiding personeelswerk heeft als enig opleidingstype uit het hoger onderwijs een slecht perspectief als gevolg van een erg hoge instroom.

\subsection{Toekomstige knelpunten in de personeelsvoorziening}

Wanneer een bepaalde opleiding een goed of zeer goed arbeidsmarktperspectief biedt, dan zal het voor de schoolverlaters met deze opleidingsachtergrond betrekkelijk gemakkelijk zijn om een baan te vinden op een functieniveau en in een -richting, waarop men toen men aan de opleiding begon zou mogen rekenen. Daarentegen zal het voor werkgevers juist problematisch zijn om schoolverlaters met deze opleidingsachtergrond aan te trekken. Een goed arbeidsmarktperspectief voor schoolverlaters zal immers doorgaans samenvallen met grote knelpunten in de personeelsvoorziening voor werkgevers.

Om een indicatie te kunnen geven van de mogelijke toekomstige wervingsproblemen met betrekking tot de verschillende opleidingstypen, is een Indicator van de Tockomstige Knelpunten in de Personeelsvoorziening (ITKP) gemaakt. Zoals in I ocl en opzel van de arbeidsmarktprognoses reeds werd aangegeven wijkt deze indicator alleen van de ITA af bij de opleidingstypen die te kampen hebben met krimpende werkgelegenheid. In dat geval zullen bedrijven immers de mogelijkheid aangrijpen om de gedwongen uitstroom van het zittende personeel af te remmen, waardoor de vereiste instroom van nieuwkomers lager wordt. Als de ITKP kleiner of gelijk is aan 1,00 worden de verwachte knelpunten in de personeelsvoorziening als groot getypeed. Is de I'T'KP kleiner dan 0.85 , dan wordt zelfs gesproken over 'zeer grote' kansen op knelpunten in de personeelsvoorziening.

Bij de bespreking van de opleidingstypen waarvoor knelpunten in de personecelsvoorziening worden verwacht, zal telkens een indicatie worden gegeven van de bedrijlssectoren die waarschijnlijk met deze knelpunten zullen worden geconfronteerd ${ }^{12}$. Nel als bij een ongunstig arbeidsmarktperspectief voor nieuwkomers op de arbeidsmarkt

12 Hierbij moet vooralsnog gebruik gemaakt worden van een eenvoudig criterium. Telkens worden alleen de bedriffssectoren genoemd waarin minimaal $5 \%$ van de werkenden met de desledreffende. opleidings-achtergrond werkzaam is. 
niet automatisch moet worden gedacht aan hoge werkloosheid, moeten knelpunten in de personeelsvoorziening, zoals reeds eerder is opgemerkt, niet zonder meer gelijk worden gesteld met de aanwezigheid van onvervulbare vacatures. Bedrijven kunnen immers op verschillende manieren op deze knelpunten inspelen: het bieden van een hogere beloning, het verbeteren van het imago, arbeidskrachten met een andere opleidingsachtergrond aantrekken, overwerk e.d. Knelpunten in de personeelsvoorziening wijzen daarom in de eerste plaats op een toename van de kosten of inspanning voor een bedrijf als ze een werkende uit het betreffende opleidingstype in dienst willen nemen.

Tabel 3.5

Zeer grote knelpunten in de personeelsvoorziening op middellange termijn naar bedrijfssector

\section{Bedrijfssector}

Basischemie

Energie

Bouw

Handel

Scheeps- en luchtvaart

Weg-en railververvoer

Horeca

Zakelijke dienstverlening
Gezondheidszorg

Onderwijs

()verheid

\section{Verwachte knelpunten}

MBO/LWW procestechniek

$\mathrm{HBO}$ vervoer en logistiek

MB0/LLW operationele techniek

HBO bouwkunde

MBO/LLW horeca

HBO informatica

$\mathrm{HBO}$ vervoer en logistiek

HBO vervoer en logistiek

MBO/LLW horeca

HBO lerarenopleiding economie en maatschappij

HBO bouwkunde

HBO informatica

HBO recht en bestuur

WO bouwkunde

WO civiele techniek

WO informatica en bestuurlijke informatiekunde

WO bedrijfskunde

WO accountancy en belastingen

MBO/LLW verpleging

MBO/LLWW horeca

HBO lerarenopleiding economie en maatschappij

WO tandheelkunde

HBO lerarenopleiding economie en maatschappi

HBO lerarenopleiding economie en matschappi

HBO bouwkunde

$\mathrm{HBO}$ informatica

$\mathrm{HBO}$ vervoer en logistiek

$\mathrm{HBO}$ recht en bestuur

W0 accountancy en belastingen

Broll: ROA

Tabel 3.5 geeft voor elke bedriffssector een overzicht van de opleidingstypen waarvoor de sector geconfronteerd wordt met zeer grote knelpunten in de personeelsvoorziening . De zeer grote knelpunten in de personeelsvoorziening doen zich vooral voor bij

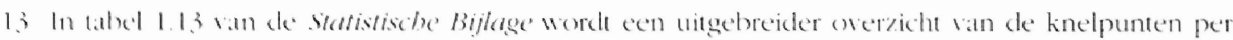
bedriftisector gepesenteded. In deze tabel wordt voor elke bedrifissector alle opleidingstypen watrvor grote of zeer grote knelpunten in de personeclswoorziening worden verwacht, in beeld getracter. 
opleidingstypen uit het hoger onderwijs. Ook zijn de zeer grote knelpunten vooral geconcentreerd in de zakelijke dienstverlening, de gezondheidszorg en de overheidssector. Dat betekent echter niet dat er geen knelpunten voor middelbare opleidingstypen in andere bedrijfssectoren worden verwacht. Zoals in tabel 1.13 van de Statistische Bijlage naar voren komt, blijken er bijvoorbeeld in de sector handel ook grote knelpunten te worden verwacht voor de opleidingstypen MAVO, VBO electrotechniek en VBO vervoer:

Toch zijn het niet alleen hogere opleidingstypen, waarvoor zeer grote knelpunten in de personeelsvoorziening worden verwacht. Ook voor enkele opleidingstypen uit het middelbaar onderwijs worden in bepaalde sectoren zeer grote knelpunten verwacht. Dat is bijvoorbeeld het geval in de basischemie, waar voor het opleidingstype MBO/LLW procestechniek zeer grote knelpunten in de personeelsvoorziening worden verwacht. Ook in de sectoren bouw, handel, boreca en gezondheidszorg zijn enkele zeer grote knelpunten voor opleidingstypen op middelbaar niveau te verwachten. In de bedrijfssector bouw gaat het hier om het opleidingstype $M B O / L L W$ operationele techniek. In de drie overige bedrijfssectoren ( handel, horeca en gezondbeidszorg) worden op middelbaar opleidingsniveau zeer grote knelpunten in de personeelsvoorziening verwacht voor $M B O / L L W$ boreca.

In de bouw worden zeer grote knelpunten in de personeelsvoorziening verwacht als gevolg van een tekortschietende arbeidsmarktinstroom van HBO bouwkunde. Voor het opleidingstype $H B O$ informatica zullen in de bedrijfssector handel zeer grote knelpunten ontstaan. Van de werkenden met deze opleidingsachtergrond is $12 \%$ in deze sector werkzaam.

Een viertal bedrijfssectoren wordt geconfronteerd met zeer grote knelpunten in de personeelsvoorziening voor het opleidingstype $H B O$ vervoer en logistiek. Het knelpunt zal het meest voelbaar zijn in de bedrifssector scheeps-en luchtwart ondat daar het werkgelegenheidsaandeel van dit opleidingstype met $15 \%$ vrij hoog is.

De zakelijke dienstvertening is de bedrijfssector met het hoogste atantal opleidingstypen waarvoor knelpunten verwacht worden. Voor matr liefst vier HBO- en vijf WO-epleddingen worden in deze sector zeer grote knelpunten in de personeelsverorziening verwacht. De HBO-opleidingen met zeer grote knelpunten zijn de IIBO lerarenopleiding economice en maatschappij. HBO boutukunde, HBO informatica en IHBO rech en bestumar. Een groot deel van de vraag naar arbeidskrachten met als opleidingsaldetergrond HBO boumkunde of IIBO informatica deet zich voor in de zakelifke dienstrertening

De zakelijke diensterlening zal ook grote problemen ondervinden bij de werving van mensen met een opleiding WO bonakunde, WO civiele technick, WO informalica en bestururlifke informatiekunde. WO bedriffsumde en WO acommancy' en belastingern. Het vale op dat een groot deel van de werkenden met deze opleidingsachtergronden werkzatam is in de sector zakelijke diensterlening.

Nalast de al eerder genoemde verwachte knelpunten voor het opleidingstype MHB( )/I.W boreca zijn er in de gezondbeidszorg een drietal andere zeer grote knelpunten te ver- 
wachten. De zeer grote knelpunten in de personeelsvoorziening voor het opleidingstype $M B O / L L W$ verpleging zal zich vrijwel geheel in deze sector concentreren. Meer dan $85 \%$ van het aantal werkenden met opleidingsachtergrond $M B O / L L W$ verpleging is namelijk in de gezondbeidszorg werkzaam. Daarnaast worden knelpunten voor de HBO lerarenopleiding economie en maatschappij en WO tandheelkunde verwacht.

In het onderwijs wordt ook een zeer groot knelpunt in de personeelsvoorziening voor het opleidingstype HBO lerarenopleiding economie en maatschappij verwacht. Zoals uit tabel 1.13 van de Statistische Bijlage blijkt, worden er in deze sector ook grote knelpunten voorzien voor de overige lerarenopleidingen op HBO-niveau.

Ook in de overheidssectorworden zeer grote knelpunten voor de HBO lerarenopleiding economie en maatschappij verwacht. Het valt overigens op dat het met name de HBOopleidingen zijn waarvoor in deze sector zeer grote knelpunten verwacht worden. Zo zullen zich ook zeer grote knelpunten voordoen bij de opleidingstypen HBO bouwkunde, HBO informatica, HBO vervoer en logistiek, en HBO recht en bestuur. Voor het opleidingstype $H B O$ recht en bestuur is de overheidssector erg belangrijk: maar liefst $48 \%$ van de werkenden met deze kwalificatie vinden emplooi bij de overheid. Het opleidingstype WO accountancy en belastingen, is de enige opleiding op WO-niveau warvoor binnen de overheidssector zeer grote knelpunten worden verwacht.

Zoals reeds eerder werd aangegeven hebben werkgevers bij de werving van nieuw personeel, bij verschillende beroepsgroepen de mogelijkheid om arbeidskrachten met een uiteenlopende opleidingsachtergrond aan te trekken. Deze substitutiemogelijkheden zullen in de praktijk worden aangegrepen om de wervingsproblemen te verlichten. In sommige gevallen zal dit echter gepaard moeten gaan met het bijscholen of omscholen van mensen met een andere opleidingsachtergrond. Met name voor een aantal beroepen in de kwartaire sector en bij de overheid blijkt deze flexibiliteit echter nauwelijks te bestaan. Voor deze beroepen, zoals de medische beroepen en de docenten van het basis en vortgezet onderwijs, zullen de verwachte knelpunten in de personeelsvoorziening daardoor walarschijnlijk zeer nijpend zijn. 


\section{Aanpassingsprocessen op de arbeidsmarkt}

In dit hoofdstuk zal worden ingegaan op de implicaties van de arbeidsmarktprognoses voor zowel de aanpassingsprocessen op de korte termijn, als voor de structurele aanpassingen en de reikwijdte van een aantal beleidsmogelijkheden. In paragraaf 4.2 zal allereerst worden ingegaan op de wijze waarop de arbeidsmarkt reageert op discrepanties tussen vraag en aanbod bij een bepaald opleidingstype. In paragraaf 4.3 wordt vervolgens een beeld gegeven van de verschuivingen in de beroepenstructuur die mede op grond van de verwachte discrepanties tussen vraag en aanbod verwacht worden. Hierbij wordt ingegaan op de aard en bet niveau van bet werk, de vereiste vaardigheden en de fisieke belasting van bet werk. In paragraaf 4.4 wordt vervolgens een beeld geschetst van de mogelijkheden die discrepanties, zoals die thans worden voorzien, bieden voor meer structurele veranderingen op de arbeidsmarkt. Hierbij zal achtereenvolgens worden ingegaan op de studiekeuze van scholieren, de participatie in de werkzame bevolking, de gemiddelde arbeidstijd en de verschuivingen in de werkgelegenbeidsontwikkeling per bedrijfssector.

\subsection{Inleiding}

In de voorgaande hoofdstukken is beschreven hoe de verwachte ontwikkelingen op de arbeidsmarkt leiden tot discrepanties tussen vraag en aanbod voor de onderscheiden opleidingstypen. De uitbreidingsvraag voor een opleidingstype wordt bepaald door de werkgelegenheidsgroei in de bedrijfssectoren waarin degenen met de desbetreffende opleidingsachtergrond emplooi vinden, de verschuivingen in de beroepenstructuur binnen deze bedriffssectoren en de verschuivingen in de opleidingstypen die voor deze functies worden gevraagd. De vervangingsvraag wordt bepaald door de leeftijds- en geslachtsopbouw van de beroepsbevolking met de desbetreffende opleidingsachtergrond en de arbeidsmarktuitstroom van de verschillende leeftijdsgroepen per gestacht. Daarbij spelen de ontwikkelingen in de participatie van met name vrouwen en oudere arbeidskrachten vanzelfsprekend een belangrijke rol. Tezamen bepalen de uitbreidingsvraag en de vervangingsvraag de haanopeningen voor de komende vijf jaren. Aan de aanbodkant van de arbeidsmarkt spelen de arbeidsmarktinstroom van schoolverlaters en de werklozen die nog op zoek zijn naar een positie op de arbeidsmarkt cen belangrijke rol.

De verwachte discrepanties tussen vraag en aanbod leiden tot uiteenlopende perspectieven voor de verschillende opleidingstypen op de arbeidsmarkt. Voor tepatalde opleidingstypen zal de vraag groter zijn dan het aanbod, terwijl voor andere opleidingstypen het aanbod de vraag overtreft. Voor de periode 1997-2002 wordt op de arbeidsmarkt voor een groot aantal opleidingstypen een aanbodtekort verwacht. Dit komt a an de ene kant door een toename van de werkgelegenheid in de komende periode en een, door vergrijzing, toenemende vervangingsvraag. Anderzijds speedt de afnemende instroom van schoolverlaters op de arbeidsmarkt een rol. Dit specelt met name op WO- en HBO-niveau, terwijl ook op MBO-niveau bij veel opleidingstypen ecn aanbodtekort wordt verwacht. De vraag- en aanbodontwikkelingen kunnen echter sterk uiteenlopen tussen opleidingstypen binnen een bepaald niveau waardoor op elk 
opleidingsniveau, met uitzondering van het basisonderwijsniveau, zowel opleidingstypen met goede als met slechte perspectieven voorkomen.

In de praktijk zullen discrepanties tussen vraag en aanbod voor bepaalde opleidingstypen leiden tot aanpassingsprocessen op de arbeidsmarkt. Hierbij kunnen korte-termijnaanpassingen en meer structurele aanpassingen op de langere termijn worden onderscheiden. Op korte termijn zal het doorgaans niet mogelijk zijn substantiële veranderingen in de omvang van vraag en aanbod tot stand te brengen. Werkgevers die zich geconfronteerd zien met aanbodtekorten voor een bepaald opleidingstype zullen echter hun wervingsbeleid aanpassen door of een vergrote inspanning te plegen om de gevraagde arbeidskrachten alsnog te werven of bij de rekrutering uit te wijken naar mensen met een andere opleidingsachtergrond. Arbeidskrachten met de desbetreffende opleidingsachtergrond zullen in die situatie ook hogere eisen stellen aan de beschikbare banen. Omgekeerd zullen schoolverlaters die een aanbodoverschot ervaren, extra inspanningen verrichten om ondanks de moeilijke arbeidsmarktsituatie alsnog aan een baan te komen. Eventueel aanvaarden zij daarbij banen die zij onder andere omstandigheden niet zouden hebben aanvaard. De consequenties van dergelijke aanpassingsprocessen zijn, dat de in dit rapport beschreven discrepanties tussen vraag en aanbod zullen leiden tot veranderende marktverhoudingen bij het werven van personeel en het zoekproces naar een baan. Bovendien zullen er als gevolg van deze discrepanties verschuivingen plaatsvinden in de opleidingsachtergrond van degenen die voor een bepaalde functie geworven worden en verschuivingen in de aard van de functies die schoolverlaters van een bepaald opleidingstype zullen verwerven.

Daarnaast valt te verwachten dat - zeker als discrepanties tussen vraag en aanbod langere tijd aanhouden - meer structurele veranderingen op de arbeidsmarkt tot stand zullen komen die vraag en aanbod voor de verschillende opleidingstypen weer meer in evenwicht brengen. Dergelijke structurele aanpassingen kunnen ontstaan door gedragsveranderingen bij vragers en aanbieders van werk, maar ook door de invloed die uitgaat van bepaalde beleidsmaatregelen. Hierbij valt te denken aan verschuivingen in het studiekeuzegedrag van scholieren, de ontwikkeling van de participatie in de werkzame bevolking, de invloed van de gemiddelde arbeidsduur op het alanbod van arbeid, of de ontwikkeling van bepaalde bedrijfssectoren aan de vraagkant van de arbeidsmarkt.

\subsection{Gevolgen van discrepanties tussen vraag en aanbod}

De werkgelegenheid van personen met een bepalde opleidingsachtergrond is veelal geconcentreerd in een in meer of mindere mate beperkt beroepsdomein. In hoofdstuk 3 werd reeds ingegalan op de omvang van de uitwijkmogelijkheden van een aantal opleidingstypen. Het feit dat de werkgelegenheid van een opleidingstype zich concentreert in enkele beroepsgroepen duidt erop dat het gevolgde onderwijs heeft geleid tot bepalalde competenties, die met name in deze beroepen van belang zijn. Ondat de beroependomeinen van opleidingstypen doorgaans ook een zekere overlap vertonen, lijkt het er op dat het hierbij niet altijd om dezelfde competenties hoeft te gatan. Het ene beroep stelt eisen atan de vooropleiding waaraan slechts één bepaalde opleiding voldoet. terwijl in andere beroepen competenties een rol spelen die in verschillende opleidingsrichtingen worden verworven. Deze laatste beroepen hebben daardoor grotere substitutiemogelijkheden bij de werving van personeel. 
De vraag welke opleidingsachtergrond de werknemers hebben, die geworven worden voor een bepaalde baan zal afhangen van de eisen die die baan, stelt aan de kennis en vaardigheden van de betrokkenen, maar ook van de 'prijs' die aan de recrutering is verbonden. Deze prijs moet ruimer worden geïnterpreteerd dan alleen de loonkosten. Ook verschillen in zoek- en wervingskosten, en de aard van het arbeidscontract kunnen kostenverschillen met zich meebrengen. Zo zal de noodzaak iemand een vaste aanstelling te bieden in plaats van een tijdelijk contract, de flexibiliteit van de werkgevers verminderen en daardoor een impliciete kostenpost zijn.

Het ligt voor de hand dat in het recruteringsbeleid een afweging gemaakt zal worden tussen deze kosten en de geschiktheid van de betrokkenen voor de functie. Als een bepaalde functie zonder al te veel productiviteitsverlies uitgeoefend kan worden door iemand met een MBO-achtergrond in plaats van een HBO'er, terwijl de kosten voor het werven van een MBO'er aanzienlijk lager liggen, zal de neiging bestaan zoveel mogelijk MBO'ers te werven voor deze functie.

Veranderingen in de beroepen waarin mensen met een bepaalde opleidingsachtergrond werken kunnen daarom twee verschillende oorzaken hebben. In de eerste plaats kan er sprake zijn van verschuivingen in de vraag, waardoor de werkgelegenheid voor een bepaald opleidingstype in een bepaald beroep sterker stijgt dan de werkgelegenheid in een ander beroep. Dit kan een gevolg zijn van een sterke werkgelegenheidsontwikkeling in een bepaalde bedrijfssector, of de toename van een bepaalde functic binnen een sector. Ook kunnen vanwege technologische of organisatorische veranderingen de opleidingseisen die een bepaalde functie stelt veranderen. Zo blijkt bijvoorbeeld de introductie van een kwaliteitszorgbeleid in de vorm van 'ISO-certicifering' of 'total quality management' in veel bedrijven te leiden tot zwaardere eisen die gesteld worden aan de opleidingsachtergrond van het personeel.

In de tweede plaats kan het beroependomein van een bepaald opleidingstype veranderen door verschuivingen in de arbeidsmarktpositie van opleidingen. De voorspelde baanopeningen voor een bepaald opleidingstype moeten darom geïnterpreteerd worden als het aantal mensen met deze opleidingsachtergrond dat aangenomen zou worden als de schaarsteverhoudingen op de arbeidsmarkt niet zouden veranderen. Als er voor een opleidingstype sprake is van een a anbodoverschot wordt het echter voor werkgevers eenvoudiger geschikte personeelsleden met de desbetreffende opleiding te vinden en kunnen zij wellicht een lager salaris of minder gunstige arbeidsvoorwatarden bieden, omdat de betrokkenen vanwege de problematische situatie op de arbeidsmarki sneller accoord zullen gaan met het werk dat zij krijgen aangeboden.

Ongekeerd zullen bij een aanbodtekort de problemen bij het werven van personecl toenemen, waardoor het salaris mogelijk zal stijgen en andere arbeidsvoorwatarden voor de werknemer gunstiger worden. Werkgevers zullen datadoor eerder geneigd zijn personen met een opleidingsachtergrond waarbij sprake is van aanbodoverschoten aan te nemen dan personen met een opleiding warvoor er juist tekorten bestaan. Dit proces wordt aangeduid met de term actieve substitutie, die ook reeds in hoofdstuk I aan de orde kwam. De consequentie is dat het deel van de banen dat beschikbatar komt voor degenen met een opleiding waarvoor overschotten bestaan, toe zal nemen en zich dus aan zal passen aan het relatief grote aanbod. De werkloosheid onder degenen mel 
de desbetreffende opleidingsachtergrond hoeft daardoor niet toe te nemen in de mate waarin in eerste instantie een aanbodoverschot wordt verwacht.

Tabel 4.1

Het effect van een aanbodoverschot op de arbeidsmarktpositie van schoolverlaters, gemiddeld voor alle opleidingstypen

Indicator

effect van aanbodoverschot

Werkloosheid

Uurinkomen

Maandinkomen

daalt**

Onderbenutting

daalt**

Werk buiten vakrichting

Tijdelijk werk

stijgt**

Deeltijdwerk

stijgt* $^{*}$

stijgt**

* = significant op 15\%-niveau; ** = significant op 10\%-niveau; - = geen substantieel effect gevonden

Dat betekent echter niet dat met deze verschuivingen in de werkgelegenheid ook de perspectieven van de betrokkenen verbeterd zijn. De consequentie van het aanbodoverschot is immers dat degenen met de desbetreffende opleidingsachtergrond werk aanvaarden in functies waarin men voorheen in veel mindere mate werkzaam was en dat bovendien de beloning voor dit werk minder gunstig zal zijn dan voorheen. Tabel 4.1 laat zien op welke wijze de arbeidsmarktpositie van een schoolverlater verandert als gevolg van discrepanties tussen vraag en aanbod op de arbeidsmarkt. Voor een zevental indicatoren van de arbeidsmarktsituatie van een schoolverlater is nagegaan in hoeverre deze reageren op veranderingen in de vraag-aanbod-verhouding. Deze indicatoren zijn de kans op werkloosheid, het uur- of maandinkomen, de kans op werk beneden het gevolgde opleidingsniveau (onderbenutting), werk buiten de eigen vakrichting, tijclelijk werk of deeltijdwerk. De tabel geeft aan wat de effecten zijn van een aanbodoverschor op de genoemde aspecten van de arbeidsmarktpositie van het desbetreffende opleidingstype. De wijze walarop de arbeidsmarktsituatie van een schoolverlatter reageert op de vralg-aanbod-verhoudingen kan overigens verschillen tussen de opleidingen. De label geeft slechts de gemiddelde reacties weer. Het blijkt dat alle opgenomen indicatoren he verwathe effect hebben. De invloed van een aanbodoverschot op de werkloosheid wordt voor het gemiddelde opleidingstype opmerkelijk genoeg niel gevonden. Watarschijnlijk is er slechts bij enkele vakspecifieke opleidingen een duidelijke relatie tussen alanbodoverschotten en werkloosheid. Een aanbodoverschot blijkt datarentegen, gemiddeld genomen, wel een duidelijke invloed te hebben op het inkomen, de kans op onderbenutting en de kans op deeltijdwerk. Voor de kans op tijclelijk werk zijn de gevonden resultaten nied substantieel.

Zoals reeds is opgemertit kunnen er voor de verschillende opleidingstypen verschillen bestain in de wijze walarop de arbeidsmarkipositie zich alanpast alan vraag-aanbod-discrepanties. Zo zal het voor schoolverlaters van bepaalde opleidingstypen in het geval van e'n a anbodowerschot mogelijk zijn om werk te vinden beneden het eigen opleidingsniveau, terwijl voor andere opleidingstypen in een dergelijk geval de werkloosheid toe zal nemen. Tabel +2 geeft een beeld van de wijze waarop de onderscheiden aampassingsmechatnismen samenhangen. 
Tabel 4.2

Relatie tussen de effecten van een aanbodoverschot

\begin{tabular}{|c|c|c|c|c|c|c|}
\hline $\begin{array}{l}\text { werk- } \\
\text { loosheid }\end{array}$ & $\begin{array}{c}\text { uur } \\
\text { inkomen- }\end{array}$ & $\begin{array}{l}\text { maand- } \\
\text { inkomen }\end{array}$ & $\begin{array}{c}\text { onder- } \\
\text { benutting }\end{array}$ & $\begin{array}{c}\text { werk } \\
\text { buiten } \\
\text { vak- } \\
\text { richting }\end{array}$ & $\begin{array}{c}\text { tijdelijk } \\
\text { werk }\end{array}$ & $\begin{array}{c}\text { deeltijd } \\
\text { werk }\end{array}$ \\
\hline
\end{tabular}

$\begin{array}{lccccccc}\text { Werkloosheid } & 1,00 & & & & & & \\ \text { Uurinkomen } & -0,40^{*} & 1,00 & & & & & \\ \text { Maandinkomen } & -0,66^{*} & 0,67^{*} & 1,00 & & & & \\ \text { Onderbenutting } & -0,53^{*} & -0,08 & -0,22 & 1,00 & & \\ \text { Werk buiten vakrichting } & 0,29^{*} & -0,51^{*} & -0,20 & 0,06 & 1,00 & \\ \text { Tijdelijk werk } & -0,13 & 0,30^{*} & -0,37^{*} & 0,67^{*} & -0,35^{*} & 1,00 & \\ \text { Deeltijdwerk } & 0,61^{*} & -0,21 & -0,87^{*} & 0,22 & -0,07 & 0,68^{*} & 1,00\end{array}$

$*$ = significant gecorreleerd op $5 \%$-niveau

Bron: ROA

De eerste kolom van de tabel laat zien dat de invloed van een aanbodoverschot op de werkloosheid samenhangt met de invloed op de andere indicatoren, met uitzondering van het werken in tijdelijke banen. Dit betekent dat opleidingstypen waarvoor de vrataaanbod-discrepanties een groot effect hebben op de kans op werkloosheid tevens veel aanpassingen vertonen in het verdiende inkomen, de kans op werk buiten de eigen vakrichting en het werken in deeltijdbanen. Echter, als bij een bepaald opleidingstype een aanbodoverschot relatief veel werkloosheid impliceert, dan is er relatief weinig sprake van onderbenutting als reactie op de discrepantie. Werkloosheid en onderbenutting zijn dus negatief aan elkaar gerelateerd.

Dit betekent dat bij veel opleidingstypen een aanbodoverschot op de arbeidsmarkt kan worden gecompenseerd door banen te accepteren die een lager niveau hebben dan de voltooide opleiding. Bij de opleidingstypen waar neerwatse verdringing daarentegen niet mogelijk is, bijvoorbeeld op de lagere opleidingsniveaus of bij bepaalde specilicke opleidingen, zal een a anbodoverschot eerder tot werkloosheid leiden. Ook hlijkt de kans op werkloosheid gecompenseerd te kunnen worden door het aanvaarden van functies met een laag inkomen, werk buiten de eigen vakrichting en deeltijdwerk. lit de negatieve relatie tussen het verdiende inkomen en de kans op werk buiten cle cigen vakrichting blijkt dat er opleidingstypen zijn waar schoolverlaters, in het geval van een aanbodoverschot op de arbeidsmarkt, toch vaak banen in hun eigen werkterrein kunnen vinden, zonder genoegen te moeten nemen met een lager uurloon. Het gatat dan wel vaker om tijdelijke banen, gezien de negatieve relatie tussen de kans op werk buiten de eigen vakrichting en de kans op tijdelijk werk. Er is eveneens een significante positieve relatie tussen de kans op tijdelijk werk en het niveau van de baan en de kans op deeltijdwerk. Verder blijkt de kans op werk buiten de eigen vakrichting gepaard te gaan met een laag uurinkomen, terwijl een laag maandinkomen vaak gepaard gaat met een hoge kans op tijdelijk werk en deeltijdwerk. Kennelijk impliceent het gedwongen uitwijken naar deeltijdbanen of werk buiten de eigen vakrichting ook een negaticve aampassing van het loon. 
Figuur 4.1

Een voorbeeld van drie opleidingstypen met een overlappend beroepsdomein

\section{MBO/LLW administratie}

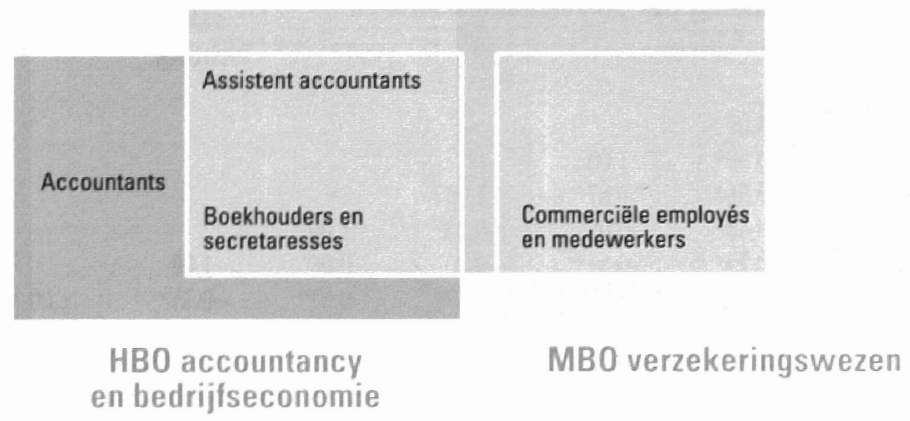

Zoals reeds is opgemerkt zullen deze verschuivingen in de arbeidsmarktsituatie van een opleidingstype ook van invloed zijn op het beroependomein van deze opleidingsichting. Figuur 4.1 illustreert hoe dergelijke mechanismen kunnen werken. In de figuur wordt het beroependomein van drie opleidingstypen weergegeven: MBO verzekeringswezen, MBO/LLW administratie en HBO accountancy en bedriffseconomie. Uit tabel 3.21 van de Statistische Bijlage blijkt dat $M B O$ verzekeringswezen en $M B O / L L W$ administratie sterke concurrentie van elkaar ondervinden op de arbeidsmarkt. Deze concurrentie wordt vooral veroorzaakt doordat uit beide opleidingstypen veel personen werk vinden in de beroepsgroepen commerciële employés en commerciële medewerkers. $M B O / L L W$ administratie en HBO accountancy en bedrijfseconomie ondervinden op hun beurt sterke onderlinge concurrentie vanwege de beroepen boekhouders en secretaresses en assistent accountants. Stel nu - bij wijze van voorbeeld - dat de vraag naar accountants sterk toeneemt. Uit tabel 3.17 van de Statistische Bijlage blijkt dat van de drie genoemde richtingen alleen personen met een opleidingsachtergrond IIBO accombancy en bedrij/seconomie in dit beroep sterk vertegenwoordigd zijn. Als gevolg van de toename van de vraag zal - als het a anbod hierop onvoldoende inspeelt - een aanbodtekort bij de laatstgenoemde opleidingsrichting resulteren. Als gevolg van dat atanboltekort en de dataruit voortvloeiende goede of zeer goede arbeidsmarktperspectieven voor dit opleidingstype zal het voor werkgevers moeilijker worden mensen met de desbetreffende opleidingsachtergrond te werven. Als een gevolg van de afweging die werkgevers bij hun recruteringsbeleid maken zullen de werkgevers, die functies willen vervullen watarvor de opleidingsachtergrond $H B O$ accommlancy en bedriffseconomie van groon belang is, bereid zijn hiervoor hogere kosten of grotere zockinspanningen voor hun rekening te nemen. Voor functies zoals assistent accountant zal men echwer meer en meer personen met de opleiding MBOLLW administratie annemen. Een dergelijke toename van de valag vanwege a anbodtekorten bij verwante opleidingstypen wordt, zoals reeds eerder werd opgemerkt, aangeduid als passieve substitutie. 1)oor deze ontwikkelingen verschuift het beroependomein van HBO accoumancy en bedriffseconomice in de richting van het beroep accountant en van IIBO LLW" administratie in de richting van assistent accountant. Als gevolg van deze verschuivingen neemt de valag nata . IIBO LLII adminsstratie eveneens toe watardoor ook hier een vergelijkbaar selecticproces platats gat vinden. De consequentie hiervan kan zijn dat per- 
sonen met deze opleidingsachtergrond minder vaak ingezet zullen worden voor de beroepen commerciële employés en commerciële medewerkers en hierdoor de werkgelegenheid naar het opleidingstype $M B O$ verzekeringswezen zal verschuiven.

Dergelijke aanpassingsmechnismen op de arbeidsmarkt betekenen dus dat, als gevolg van de verwachte arbeidsmarktperspectieven van opleidingstypen, ook de aard van het beroependomein waarin zij werk zullen vinden, zal veranderen. In de volgende paragraaf zal hierop verder worden ingegaan.

\subsection{Verwachte veranderingen in de aard van het werk}

De vraag in de verschillende beroepsgroepen ontwikkelt zich niet overal even sterk. Als gevolg daarvan kunnen er in de werkgelegenheid van bepaalde opleidingstypen verschuivingen ontstaan in de beroepen die men uitoefent. Verder zullen, zoals in de vorige paragraaf werd aangegeven, discrepanties tussen vraag en aanbod er ook toe leiden dat het beroependomein van een bepaald opleidingstype van karakter verandert. Bij aanbodtekorten zullen marktkrachten er voor zorgen dat de werkgelegenheid zich concentreert in die beroepen, waarvoor de desbetreffende opleidingsachtergrond het meest cruciaal is. Omgekeerd zullen personen met een opleidingsachtergrond walavoor er een aanbodoverschot bestaat, uitwijken naar beroepen watrin zij relatief gemakkelijk aangenomen worden.

\section{Beroepsterrein}

Het beroependomein waarin mensen met een bepaalde opleidingsachtergrond werkzaam zijn laat zich op verschillende manieren karakteriseren. Allereerst kan er een onderscheid worden gemaakt naar beroepsterrein. Zo kan worden nagegaan wat de opleidingsachtergrond is van degenen die werkzaam zijn in een bepaald beroep ${ }^{1+}$. Op basis van deze informatie kan dan aangegeven worden welke opleidingsrichting kennelijk vereist is voor een bepaald beroep. Beroepen watrin bijvoorbeeld het overgerete deel van de werkenden een technische opleiding heeft genoten, worden op deze wijze als 'technisch' getypeed. Beroepen watrin werkenden een sterk uiteenlopende opleidingsachtergrond hebben, worden daarentegen als 'niet-vakspecifiek' getypectel. Op deze wijze zijn alle beroepsgroepen van een typering van de vereiste opleidingsrichting voorzien. Op basis van deze typering van het beroepsterrein kan worden vastgested welk aandeel van de werkenden met een bepaalde opleidingsachtergrond werkzatm is in een vakspecifiek beroep voor her desbetreffende opleidingstype

Tabel 4.3 geeft per opleidingsniveau een beeld van het percentage werkenden diat emplosi vindt in het vakspecifieke beroepsterrein. Uit de tabel blijkt dat hel percentage werkenden dat een beroep uitofent in de eigen vakrichting duidelijk toeneemt met hel opleidingsniveau. Terwijl van de werkenden met een VBO-opleiding matr 25\% binnen de eigen vakrichting werkzalam is, is dit bij de werkenden met een HBO- of WO-opleiding meer dan $50 \%$. Kennelijk wordt naarmate mensen over meer mensclijk kapital beschikken, hun kennis en vaardigheden steeds specifieker ingeret. Ook in hoofdstuk

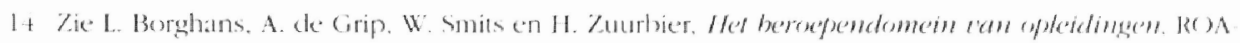
R-1907 2. Maastricht. 1907. 
3 bleek reeds dat het volgen van een hogere opleiding tot minder uitwijkmogelijkheden op de arbeidsmarkt leidt. Naarmate het opleidingsniveau stijgt wordt het kennelijk steeds moeilijker kennis en vaardigheden efficiënt in te zetten buiten een specifiek beroepsdomein.

\section{Tabel 4.3}

\section{Percentage werkenden per opleidingsniveau dat werkzaam is binnen het eigen vakspecifieke} beroepsterrein in 1997 en 2002

\section{Opleidingsniveau}

Basisonderwijs

VBO, MAVO

MBO/LLW, HAVO/WWO

$\mathrm{HBO}$

WO
1997

1997
$\%$

25
41
51
55

2002

$\%$

23

39

51

51

Bron: ROA

Op basis van gegevens over de onderliggende opleidingstypen kan worden nagegaan welke opleidingen het sterkst bijdragen aan deze verschillen. Opleidingstypen met het laagste percentage werkenden binnen het eigen vakspecifieke beroepsterrein zijn opleidingen die zich richten op een beroepsterrein dat in de praktijk open staat voor mensen met sterk uiteenlopende achtergronden. Het betreft hier onder meer de opleidingen VBO verzorging en VBO beveiliging waar meer dan $95 \%$ van alle werkenden met die opleidingsachtergrond actief is buiten het eigen beroepsterrein. Daarbij moet opgemerkt worden dat beroepen zoals bijvoorbeeld hulpkrachten horeca en verzorging of aspirant politieagenten, soldaten en beveiligingshulpkrachten niet als vakspecifieke beroepen zijn getypeerd. Dit komt omdat personen met een opleiding verzorging of beveiliging slechts een beperkt aandeel hebben in de werkgelegenheid van de desbetreffende beroepen. Kennelijk is de vereiste opleidingsrichting voor deze beroepen niet erg specifiek. Opvallend is dat ook HBO openbare orde en veiligheid en HBO commumicatie en journalistiek meer dan 95\% van de werkgelegenheid buiten het eigen vakgebied hebben. Bij het latstgenoemde opleidingstype komt dit doordat het heroep journalisten niet getypeerd is als een vakspecifiek beroep voor de opleidingen op sociaal/cultureel gebied en letteren, omdat in dit beroep ook veel mensen met een geheel andere opleidingsachtergrond werkzaam zijn. Verder zijn ook veel personen met de opleidingsachtergrond HBO communicatie en jommalistiek werkzaam in het beroep commercied medewerkers. Dit beroep is uiteratard ook geen typisch beroep voor dit opleidingstype.

De opleidingsrichtingen met de hoogste percentages werkenden binnen het eigen vakspecifieke domein zijn zeer herkenbaar. Hier komen we opleidingen zoals WO tandbeelkunde. WO accomutancy en belastingen en WO (dier)geneeskunde tegen. Van deze opleidingen is bekend dat mensen die dit gaan studeren, dit ook vali doen met het oog op een specifiek aansluitend beroep zoals arts of register-accountant. Meer dan $90 \%$ van de personen met deze opleidingsachtergrond is werkzaam in het eigen vakgebied. Ook voor HBO (fisio)therapie en MBOLLW installatietechniek is de werkgelegenheid binnen het eigen vakdomein met meer dan $80 \%$ als erg hoog te karakteriseren. 
Tabel 4.3 geeft ook een indruk van de ontwikkeling die het belang van deze werkgelegenheid in het vakspecifieke domein naar verwachting de komende jaren door zal maken. Opvallend is dat voor alle opleidingsniveaus een verschuiving verwacht wordt naar beroepen buiten het vakspecifieke domein. Deze tendens wordt veroorzaakt doordat de beroepsgroepen die geen specifieke vaktypering hebben sterker groeien dan de beroepsgroepen die wel eenduidig aan een bepaalde vakrichting zijn gekoppeld. Dat kan betekenen dat juist de beroepen waarvoor geen specifieke opleidingsachtergrond vereist is, sterker groeien dan de beroepen waarbij zeer specifieke competenties een rol spelen. Waarschijnlijk gaat het hierbij echter met name om 'nieuwe' beroepen, waarvoor nog geen toegespitste opleiding bestaat, of de op deze beroepen toegespitste opleidingen nog onvoldoende schoolverlaters hebben aangeleverd om in de vratag te voorzien. Juist als deze beroepen verder groeien valt te verwachten dat het onderwijssysteem hier in de toekomst op reageert door nieuwe op deze beroepen gerichte opleidingen te starten en verder uit te bouwen. Opmerkelijk is de sterke daling van het aandeel van de werkgelegenheid in het vakspecifieke beroepsdomein voor het WO, waar de werkgelegenheid in het vakspecifieke domein met maar liefst 4\%-punten daalt. Bij het $\mathrm{VBO} / \mathrm{MAVO}$, het $\mathrm{MBO} /$ leerlingwezen en HAVO/VWO betreft de daling 2\%-punten. $\mathrm{Bij}$ het $\mathrm{HBO}$ is de daling daarentegen zeer gering.

Tabel 4.4

Werkgelegenheidsontwikkeling per opleidingsniveau uitgesplitst naar de effecten in de verschillende beroepsterreinen, 1997-2002

Opleidingsniveau

$\begin{array}{cc}\begin{array}{c}\text { Bedrijfs- } \\ \text { sector- } \\ \text { effect }\end{array} & \begin{array}{c}\text { Beroeps- } \\ \text { effect }\end{array} \\ & \%\end{array}$

Basisonderwijs

vakspecifiek

overig

VBO, MAVO

vakspecifiek

overig

MBO/LLW, HAVO/VWO

vakspecifiek

overig

$\mathrm{HBO}$

vakspecifiek

overig

WO

rakspecifiek

overig

Bron: ROA

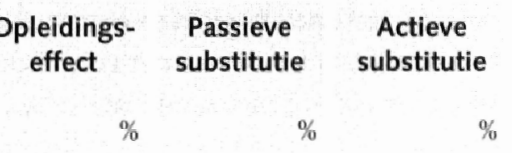
$\%$

(1)


bestuur, MBO/LLW operationele techniek en VBO brood en banket wordt verwacht dat zij steeds vaker werk zullen vinden buiten hun specifieke vakgebied. Daarentegen wordt voor werkenden met een opleiding WO civiele techniek, WO werktuigbouwkunde, WO theologie, HBO secretariaat en MBO/LLW vliegtuigtechniek of MBO/LLW procestechniek een verschuiving van de werkgelegenheid naar het eigen vakdomein verwacht. Alleen op VBO/MAVO-niveau worden geen opleidingsrichtingen aangetroffen waarvoor zich noemenswaardige verschuivingen van de werkgelegenheid in de richting van het vakspecifieke domein voordoen.

Om meer inzicht in de verschuivingen in het beroependomein te krijgen is het van belang om de verschillende oorzaken van deze ontwikkelingen te scheiden. In tabel 4.4 worden de verschuivingen in de vraag in het vakspecifieke en het niet-vakspecifieke domein daarom opgesplitst in de verschillende componenten van de uitbreidingsvraag, zoals die ook in hoofdstuk 1 zijn onderscheiden.

Het bedriffssectoreffect geeft weer wat de uitbreidingsvraag is naar arbeidskrachten met het desbetreffende opleidingsniveau als gevolg van de verwachte groei van de bedriffssectoren waarin personen met die opleidingsachtergrond werkzaam zijn. Dit bedrijfssectoreffect is op alle opleidingsniveaus hoger in het niet-vakspecifieke domein dan in het vakspecieke domein. Dit betekent dat de verwachte bedrijfssectorontwikkeling over het algemeen dus al aanleiding geeft tot de in tabel 4.3 geconstateerde verschuiving van de werkgelegenheid naar de niet-vakspecifieke beroepen. Kennelijk groeien de bedrijfssectoren waarin veel specifieke vakspecialismes aanwezig zijn minder hard dan de bedrijfssectoren waarin veel functies minder duidelijke opleidingsprofielen vereisen. Het gaat hierbij met name om een verschuiving van de industrie naar de dienstensector.

Het beroepseffect geeft de additionele vraag voor bepaalde opleidingen weer, die voortkomt uit de groei van bepaalde beroepen ten opzichte van andere beroepen waarin personen met die opleidingen sterk vertegenwoordigd zijn. Zoals in hoofdstuk 1 reeds werd geconstateerd, neemt de werkgelegenheid toe in beroepen watrin de hogere opleidingsniveatus sterker zijn vertegenwoordigd ten koste van de beroepen waarin met name lagere opleidingsniveaus sterk zijn vertegenwoordigd. Opmerkelijk is dat bij het HBSO deze toename in de vraig volledig betrekking heeft op functies buten het vakspecifieke domein. Het beroepseffect binnen het vakspecifieke domein is zelfs negat ief. Voor hed WO daarentegen is het beroepseffect binnen het vakspecifieke domein groter dan databuiten.

Het opleidingseffect geeft aan in hoeverre binnen de beroepen waarin degenen met het destetreffende opleidingsniveau werkzaam zijn de vaag naar hun opleidingsachtergrond toe- of afneemt. Het is opmerkelijk dat de upgrading van de vratag van lagere naar hogere opleidingsnivealus binnen de verschillende beroepsgroepen zich met name buiten het vakspecifieke domein blijkt af te spelen. Met name voor het MBO/leerlingwezen en hee WO is het opleidingseffect voor het niet-vakspecifieke domein veel sterker dan voor het vakspecifieke domein. Voor het HBO geldt dit in veel mindere mate. Bij een a antal vakspecifieke beroepen is er sprake van een upgrading van cle functievereisten van MBO/eerlingwezen- naar HBO-niveau.

De verschuivingen in de werkgelegenheid als gevolg van het bedriffsectoreffect, het 
beroepseffect en het opleidingseffect staan nog los van de invloed die uitgaat van de voorspelde aanbodtekorten of -overschotten. Als er voor een bepaald opleidingstype onvoldoende aanbod is om in de vraag te voorzien, zullen werkgevers personen met een verwante opleidingsrichting gaan werven. Dit is het zogenaamde passieve-substitutie-effect. Zowel op HBO- als op WO-niveau blijkt deze passieve substitutie zich met name buiten het vakspecifieke domein af te spelen. Dit ligt voor de hand ondat over het algemeen werkgevers in de niet-vakspecifieke beroepen meer alternatieven hebben dan in het vakspecifieke domein. Bij een tekortschietend aanbod zal echter niet in alle vraag naar arbeidskrachten met de desbetreffende opleidingsachtergrond kunnen worden voorzien. Deze rantsoenering van de vraag doet zich voor wanneer het actieve-substitutie-effect negatief is. Uit de laatste kolom van tabel 4.4 blijkt dat als gevolg van de marktwerking met name de plaatsen waar de desbetreffende opleidingsachtergrond minder cruciaal is niet volledig zullen worden vervuld. Voor het $\mathrm{HBO}$ betekent dit, dat - zoals verwacht mag worden - met name buiten het vakspecifieke domein een aanzienlijk deel van de vraag uiteindelijk niet vervuld zal worden. Voor het $\mathrm{MBO} /$ leerlingwezen en het wO blijkt echter het omgekeerde te gelden. Vanwege de relatieve schaarste aan personeel blijven er relatief veel plaatsen binnen het vakspecificke domein onvervuld, zodat er per saldo een verschuiving van de werkgelegenheid natar het niet-vakspecifieke domein plaatsvindt.

\section{Opleidingsniveau}

Een tweede invalshoek bij de karakterisering van het beroependomein van de werkenden met een bepaalde opleidingsachtergrond betreft het niveau van het werk. Dit opleidingsniveau van beroepen kan op verschillende wijzen worden vastgesteld. In tabel 3.24 van de Statistische Bijlage wordt per opleidingstype aangegeven welk deel van de schoolverlaters zelf van oordeel is, dat het vereiste opleidingsniveau voor de functie die zij uitoefenen lager is dan hun eigen opleidingsniveau. In deze paragraaf is het niveau van de verschillende beroepsgroepen daarentegen getypeerd door na te gaan wat het opleidingsniveau van de werkenden in dit beroep doorgatans is. Voor een groot aantal beroepsgroepen wordt op deze wijze niet een uniek niveau gevonden, maar blijken de werkenden een uiteenlopend opleidingsniveau te hebben. Enerzijds weerspiegelt dit de heterogeniteit van de desbetreffende beroepsgroepen en de werkenden hierin. Zo zal werkervaring in bepaalde beroepen een duidelijk sulstituut zijn voor een hogere opleiding. Aan de andere kant kan het echter ook vanuit de optick van de werkgever begrijpelijk zijn dat mensen van verschillende opleidingsniveaus worken geworven voor dezelfde functie. Als binnen een bepaald beroep het loonverschil tussen werknemers met een hoger en een lager opleidingsniveau correspondeen met hun productiviteitsverschil in deze functie, zal een werkgever immers geen sterke voorkeur voor éen van beide opleidingsniveaus hebben.

Tabel 4.5 geeft per opleidingsniveau een beeld van het percentage werkenden dat op grond van deze typeringen een beroep heeft beneden of boven he gevolgde opleidingsniveau. Doordat wetenschappelijk onderwijs het hoogst onderscheiden niveatu is. is het niet mogelijk dat WO-opgeleiden boven hun opleidingsniveau werkzaam zijn. Om vergelijkbare reden kunnen werkenden met alleen basisonderwijs als opleidingsachtergrond niet beneden hun niveau werkzaam zijn. Omdat er bij de classificatic van beroepsgroepen echter geen enkel beroep uitsluitend als basisonderwijs is getypeerd. 
maar alleen combinaties met VBO en eventueel $\mathrm{MBO}$ voorkomen, kan het bij deze definitie van het begrip ook niet voorkomen dat VBO'ers beneden hun niveau werken.

Tabel 4.5

Percentage werkenden per opleidingsniveau dat werkzaam is in een functie onder, op, of boven het eigen opleidingsniveau in 1997 en 2002

\begin{tabular}{lrrrrrr} 
& \multicolumn{2}{c}{ onder niveau } & \multicolumn{2}{c}{ eigen niveau } & \multicolumn{2}{c}{ boven niveau } \\
Opleidingsniveau & 1997 & $\mathbf{2 0 0 2}$ & $\mathbf{1 9 9 7}$ & $\mathbf{2 0 0 2}$ & $\mathbf{1 9 9 7}$ & $\mathbf{2 0 0 2}$ \\
& $\%$ & $\%$ & $\%$ & $\%$ & $\%$ & $\%$ \\
Basisonderwijs & - & - & 49 & 43 & 51 & 57 \\
VBO, MAVO & - & - & 67 & 67 & 33 & 33 \\
MBO/LLW, HAVO/NWO & 7 & 7 & 86 & 87 & 7 & 6 \\
HBO & 24 & 24 & 71 & 71 & 5 & 5 \\
WO & 32 & 35 & 68 & 65 & - & -
\end{tabular}

Bron: ROA

De tabel laat zien dat de onderbenutting, in de zin van het percentage werkenden dat werk heeft onder het gevolgde opleidingsniveau, toeneemt met het opleidingsniveau. Van de middelbaar opgeleiden werkt slechts $7 \%$ beneden het eigen opleidingsniveau, terwijl van de WO'ers $32 \%$ werk heeft op een gezien hun opleidingsachtergrond te laag functieniveau. De hoogste onderbenuttingspercentages worden dan ook bij opleidingstypen uit het hoger onderwijs gevonden, zoals $H B O$ toerisme en recreatie $(76 \%)$, HBO landbouw en veeteelt (59\%), WO econom(etr)ie (53\%), WO informatica en bestuurlijke informatiekunde (51\%) en WO elektrotechniek (49\%). Voor het aandeel van de werkgelegenheid boven het opleidingsniveau geldt de omgekeerde tendens. Het percentage werkenden dat werkzaam is boven het gevolgde opleidingsniveau loopt af van $51 \%$ bij basisonderwijs tot $5 \%$ bij het HBO. Naast het basisonderwijs worden hier de hoogste percentages alangetroffen bij VBO fijmmechanische techniek, VBO elektrotechniek, VBO lamdboure en naturrlijke omgeving en VBO grafische techniek. Voor al deze opleidingstypen werkt meer dan $40 \%$ boven het opleidingsniveau.

Het perentage werkenden dat werkzatm is op het eigen opleidingsniveau is het hoogst voor het MBO/leerlingwezen. Op dit opleidingsniveau wordt zowel relatief weinig boven als onder het gevolgde opleidingsniveau gewerkt. Bij deze sterk beroepsgerichte opleidingen vindt datrdoor gemiddeld $86 \%$ van de werkenden emplooi op het eigen niveau. Het opleidingstype $M B O L L W$ bout scoort hierbij het laagste, maar zelfs hier blijkt nog 70\% van de werkgelegenheid op het eigen niveaut te zijn. Naast de middellate opleidingen is dit percentage werk op het eigen opleidingsniveau ook hoog vor de valkspecificke opleidingen WO tandbeelkunde (100\%) en WO (dier)geneeskamde (95\%) en HBO (fiso) therapie (89\%), matar ook voor HBO informatica $(87 \%)$.

Dit beeld zal de komende jaren natr verwachting vrij stabiel blijven. Alleen voor degenen met slechts basisonderwijs is er een toename van de werkgelegenheid in de berocpen watrvoor in feite een hoger opleidingsniveau is vereist. Bij het WO zal daarentegen het deel van de werkenden dat werkzatam is beneden het gevolgde opleidingsnivealu stijgen. Bij het basisonderwijs wordt dit veroorzalakt doordat de werkgelegenheid 
in de ongeschoolde beroepen krimpt. Omgekeerd blijken voor de hoger opgeleiden met name de banen op HBO-niveau sterker te groeien dan de functies op academisch niveau.

De voorspelde aanbodtekorten bij een groot aantal opleidingen blijken overigens een belangrijke oorzak te zijn van de verschuivingen in het beroependomein van bepaalde opleidingstypen. Zo zal als gevolg van de verwachte tekorten bij de opleidingstypen $H B O$ secretariaat, $H B O$ verpleegkunde en $H B O$ transport de werkgelegenheid op het eigen niveau aanzienlijk stijgen. Voor $H B O$ secretariaat gaat het om een stijging van $41 \%$ naar $54 \%$; voor $H B O$ verpleegkunde van $81 \%$ naar $87 \%$ en voor $H B O$ transport van $74 \%$ naar $95 \%$. De toenemende schaarste aan mensen met deze opleidingsachtergronden zal er toe leiden dat zij in toenemende mate ingezet zullen worden in beroepen die sterker aansluiten bij de desbetreffende opleidingen. Hoewel ook HBO bestuur en recht een goed arbeidsmarktperspectief tot 2002 kent, zal voor dit opleidingstype de werkgelegenheid juist verschuiven naar werk beneden het eigen opleidingsniveau. De sterke vraag voor dit opleidingstype blijkt vooral voort te komen uit een toenemende vraag in functies op MBO/leerlingwezen-niveau.

Tabel 4.6

Werkgelegenheidsontwikkeling per opleidingsniveau uitgesplitst naar de effecten in de verschillende baanniveaus

\section{Opleidingsniveau}

Basisonderwijs

eigen

boven

VBO, MAVO

onder

eigen

boven

MBO/LLW, HAVO/VWO

onder

eigen

boven

$\mathrm{HBO}$

onder

eigen

boven

WO

onder

eigen

Bron: ROA
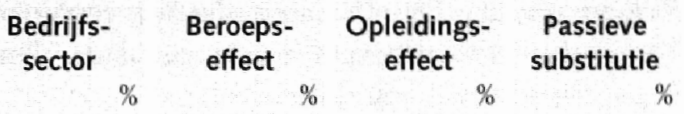

Actieve substitutie $\%$

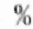

10,5

$$
-4,2
$$

$-1,2$

$$
\begin{aligned}
& -22,0 \\
& -27,1
\end{aligned}
$$

0,6

15,0

47,4 
fect op alle opleidingsniveaus groter is voor de functies onder het gevolgde niveau. Dat betekent dat met name de bedrijfssectoren, waarin relatief veel laaggeschoold werk te vinden is, sterk groeien. De ontwikkeling van de beroepenstructuur binnen deze bedrijfssectoren levert overigens een tegenwicht tegen deze tendens. Het beroepseffect is negatief voor de vraag naar arbeidskrachten met alleen basisonderwijs en VBO'ers in functies op hun eigen niveau en voor de vraag naar MBO'ers in functies onder hun niveau. Omgekeerd blijkt het beroepseffect het hoogst te zijn voor HBO'ers in functies boven hun niveau en WO'ers in functies op hun eigen niveau.

Ook het opleidingseffect laat een aanzienlijke verschuiving van de vraag in de richting van de hogere opleidingsniveaus zien. VBO'ers verliezen vanwege deze upgradingstendens vecl vraag in functies boven hun niveau, terwijl MBO'ers terrein winnen in functies beneden hun niveau. Een vergelijkbare verschuiving wordt aangetroffen bij aan de ene kant MBO'ers met betrekking tot de vraag in beroepsgroepen boven hun niveau en aan de andere kant in HBO'ers beroepen onder hun niveau. Ook voor universitair opgeleiden is het opleidingseffect het sterkst bij de functies onder hun niveau.

De passieve substitutie doet zich ook met name voor in de beroepsgroepen op een hoger opleidingsniveau. De sterkste passieve substitutie - die voorkomt uit aanbodtekorten bij verwante opleidingstypen - doet zich bij het MBO/leerlingwezen en het HBO voor bij de beroepsgroepen boven het eigen niveau en bij het WO bij de werkgelegenheid op het eigen niveau. Dit illustreert dat bij een tekortschietend aanbod voor bepaalde opleidingstypen werkgevers in een aantal gevallen arbeidskrachten met een lagere opleidingsachtergrond aantrekken.

De actieve substitutie geef - als deze positief is - aan in welke beroepen werkenden met een opleidingsachtergrond waarvoor er een aanbodoverschot is, door een verhevigde concurrentie alsnog werk zullen vinden. Voor degenen met alleen basisonderwijs blijkt een dergelijke verhoogde concurrentie met name tot werk in functies boven het eigen opleidingsniveau te leiden, omdat werk op het eigen niveau steeds minder beschikbatar is. Een negatieve actieve substimtie geeft daarentegen alan welke werkgelegenheid niet meer vervuld zal worden als gevolg van het verwachte alanboltekort Met name op HBO-niveau leiden deze tekorten tot een sterke reductie van het aantal werkenden in functies op een lager niveau.

\section{Vereiste vaardigheden}

De verschillende beroepen waltrin mensen met een bepalalde opleidingsachtergrond werkzaam zijn, kunnen uiteenlopende vaardigheden vereisen. Zowel verschuivingen in de vratag als substitutieprocessen als gevolg van vrag-aanbod-discrepanties kunnen derhalve to verschuivingen leiden in de atard van de vereiste valadigheden in de functies walar degenen met een bepalalde opleidingsachtergrond emplooi vinden. Op grond van een lypering van beroepen natar vereiste valardigheden in de nieuwe beroepenclassificatie van het CBS ${ }^{4}$, is een indicator ontwikkeld die per beroepsgroep angeeft in

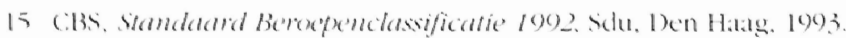


welke mate vakspecifieke vaardigheden, managementvaardigheden, communicatieve vaardigheden, algemene vaardigheden en kunstzinnige vaardigheden vereist zijn ${ }^{\text {to }}$.

Tabel 4.7 geeft per opleidingsniveau de verwachte verschuivingen in de vraag naar deze vijf vaardigheden weer, aangevuld met de verschuivingen in de vraag die betrekking hebben op functies waarvoor geen specifieke vaardigheden zijn vereist. Vakspecifieke vaardigheden hebben betrekking op kwantitatieve, technische en handvaardigheden. Deze blijken met name voor de ongeschoolden en het VBO- en $\mathrm{MBO} / \mathrm{LLW}$-niveau van belang te zijn. Echter ook voor HBO'ers en WO'ers blijken deze vakspecifieke vaardigheden in bijna de helft van de functies een rol te spelen. Het is opmerkelijk dat voor het $\mathrm{HBO}$ en WO een toename van het belang van vakspecifieke vaardigheden wordt verwacht, gezien het afnemende percentage dat emplooi vindt in het eigen vakspecifiek beroepsterrein. Deze stijging kont met name voort uit een toenemend belang van kwantitatieve vaardigheden in de functies waarin hoger opgeleiden emplooi vinden. Op MBO- en VBO-niveau daalt het belang van de vakspecifieke valardigheden. Deze daling wordt met name veroorzaakt door het afnemend werkgelegenheidsaandeel van beroepen waarbij technische en handvaardigheden van belang zijn. $\mathrm{MBO}$ - en VBO-opleidingen zijn uiteraard sterk gericht op dergelijke functies. Voor het werkterrein waarin degenen met alleen basisonderwijs emplooi vinden, wordt daarentegen wel een stijging van het belang van de vakspecifieke vardigheden verwacht. Dit komt omdat vanwege het verdwijnen van werk waarvoor überhaupt geen vaardigheden worden vereist, ook ongeschoolden steeds vaker terecht komen in functies warvoor bepaalde vaardigheden vereist zijn. Hierdoor stijgt voor ongeschoolden het belang van alle genoemde vaardigheden. Deze tendens onderstreept de toenemende spanning tussen de vereiste vaardigheden en de eigen opleidingsachtergrond waar ongeschoolden mee te maken krijgen. Meer en meer worden zij geconfronteerd met werk walrvoor zij in ieder geval formeel gezien onvoldoende kwalificaties hebben. Deels zullen zij deze achterstand kunnen compenseren door hun werkervaring, maar deels duidt dit ook op een evidente scholingsbehoefte aan de onderkant van de arbeidsmarkt.

Het belang van managementeaardigheden blijkt op alle opleidingsniveats toe te nemen. De enige uitzondering hierbij is het MBO/leerlingwezen-niveau waar een lichte daling op zal treden in het belang van managementvaardigheden voor de functies waarin degenen met deze opleidingsachtergrond werkzaam zijn. Ook de behoefte a an communicatieve vaardigheden daalt op dit opleidingsniveau enigszins. Deze daling hangt in beide gevallen samen met de al eerder geconstateerde lichte daling van het aandeel MBO'ers dat werk vindt in functies op HBO-niveau. Voor de hoger opgeteiden blift het belang van communicatieve vaardigheden op hetzelfde hoge niveau liggen. Voor degenen met alleen basisonderwijs en de VBO'ers stijgt naar verwachting hee belang van communicatieve vardigheden in de functies walan men werkzatam is.

Naast communicatieve vaardigheden wordt de laatste tijd veed gewezen op hed betang van zogenaamde algemene vaardigheden. Deze algemene vardigheden heblen hier

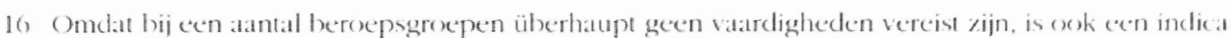

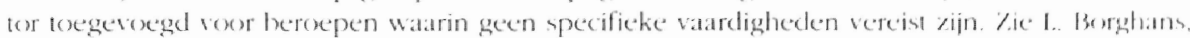
A. de Grip. W. Smits. H. Zuurbier, Itet beroefendomein ian opleidingen. ROA-R-196)7, 2. Natastich. $199^{-}$. 
betrekking op het vermogen om het werk te ordenen en te organiseren, ruimtelijk voorstellingsvermogen en oplettendheid. Opmerkelijk genoeg blijkt voor alle opleidingsniveaus, met uitzondering van degenen met alleen basisonderwijs, het belang van deze algemene vaardigheden iets af te nemen. De oorzak van deze afname is dat met name ruimtelijk voorstellingsvermogen en oplettendheid vereiste vaardigheden zijn die door het CBS veelal gekoppeld zijn aan technische bezigheden zoals monteren en repareren. Hierdoor zijn deze algemene vaardigheden vaak gekoppeld aan duidelijke vakspecialismes, terwijl de werkgelegenheidsontwikkelingen meer een tendens in de richting van meer algemeen georiënteerde beroepen in de dienstverlening laten zien.

Kunstzinnige vaardigheden blijken op de meeste opleidingsniveaus vrijwel geen rol te spelen. Alleen op HBO-niveau bestaan er vanwege het werk van kunstenaars en grafisch ontwerpers, die vaak dit opleidingsniveau hebben, functies waarvoor kunstzinnige vaardigheden zijn vereist. De vraag naar deze vaardigheden blifft naar verwachting vrijwel constant. Daarnaast is er een aantal beroepen waarbij er geen specifieke vaardigheden vereist worden. Zoals reeds eerder werd opgemerkt, zijn ook in de functies waarin ongeschoolden werkzaam zijn steeds vaker bepaalde vaardigheden vereist. Voor de werkenden op VBO- en MBO/LLW-niveau wordt daarentegen een lichte stijging verwacht van de werkgelegenheid in de beroepen waarvoor geen specifieke vaardigheden worden vereist. Met name voor de VBO'ers lijkt de werkgelegenheidsstructuur steeds dichter bij die van de ongeschoolden te komen liggen, waardoor de afnemende hoeveelheid werk waarvoor geen specifieke vaardigheden zijn vereist steeds meer door beide groepen wordt verricht.

Tabel 4.7

Percentage werkenden per opleidingsniveau dat werkzaam is in functies waarvoor bepaalde vaardigheden vereist zijn in 1997 en 2002

\begin{tabular}{|c|c|c|c|c|c|c|}
\hline \multirow[b]{2}{*}{ Opleidingsniveau } & \multicolumn{2}{|c|}{$\begin{array}{l}\text { vakspecifieke } \\
\text { vaardigheden }\end{array}$} & \multicolumn{2}{|c|}{$\begin{array}{l}\text { management } \\
\text { vaardigheden }\end{array}$} & \multicolumn{2}{|c|}{$\begin{array}{l}\text { communicatieve } \\
\text { vaardigheden }\end{array}$} \\
\hline & $\begin{array}{r}1997 \\
\%\end{array}$ & $\begin{array}{r}2002 \\
\%\end{array}$ & $\begin{array}{r}1997 \\
\%\end{array}$ & $\begin{array}{r}2002 \\
\%\end{array}$ & $\begin{array}{r}1997 \\
\%\end{array}$ & $\begin{array}{r}2002 \\
\%\end{array}$ \\
\hline Basisonderwijs & 69 & 73 & 2 & 3 & 2 & 28 \\
\hline VBO, MAVO & 72 & 70 & 3 & 4 & 37 & 37 \\
\hline MBO/LIWW, HAVONWO & 66 & 65 & 7 & 7 & 56 & 55 \\
\hline HBO & 48 & 49 & 13 & 14 & 82 & 82 \\
\hline \multirow[t]{2}{*}{ WO } & 48 & 49 & 14 & 15 & 87 & 87 \\
\hline & \multicolumn{2}{|c|}{$\begin{array}{c}\text { algemene } \\
\text { vaardigheden }\end{array}$} & \multicolumn{2}{|c|}{$\begin{array}{l}\text { kunstzinnige } \\
\text { vaardigheden }\end{array}$} & \multicolumn{2}{|c|}{$\begin{array}{l}\text { geen specifieke } \\
\text { vaardigheden }\end{array}$} \\
\hline \multirow[t]{2}{*}{ Opleidingsniveau } & 1997 & 2002 & 1997 & 2002 & 1997 & 2002 \\
\hline & $\%$ & $\%$ & $\%$ & $\%$ & $\%$ & $\%$ \\
\hline Basisonderwijs & 42 & 45 & 0 & 0 & 15 & 11 \\
\hline VBO, MANO & 46 & 45 & 0 & 0 & 9 & 9 \\
\hline MBO/LLW, HAVOAWO & 52 & 51 & 1 & 1 & 3 & 3 \\
\hline $\mathrm{HBO}$ & 4.3 & 43 & 2 & 2 & 0 & 0 \\
\hline WO & 48 & 46 & 1 & 1 & 0 & 0 \\
\hline
\end{tabular}

Bron: ROA 
Als laatste aspect, dat de aard van het werk typeert, zal worden ingegaan op de kans dat werkenden geconfronteerd worden met fysiek belastend werk ${ }^{1-}$. Tabel 4.8 geeft per opleidingsniveau voor zowel het vakspecifieke als het niet-vakspecifieke beroepsterrein aan in welke mate de werkenden in fysiek belastende functies werkzaam zijn. Fysiek belastend werk neemt duidelijk af met het opleidingsniveau. Dit geldt voor zowel het vakspecifieke als het niet vakspecifieke beroepsdomein. Bij universitair opgeleiden komt fysiek belastend werk slechts zeer sporadisch voor, maar voor HBO'ers is nog altijd ongeveer $15 \%$ van het werk fysiek belastend. Hierbij speelt vooral het werk in de verpleging en de paramedische beroepen een belangrijke rol. Voor ongeschoolden, VBO'ers en MBO'ers komt vooral in het vakspecifieke domein veel fysiek belastend werk voor. Met name vanwege de verschuiving van de werkgelegenheid in de richting van het niet-vakspecifieke domein valt op alle niveaus een daling van het fysiek belastende werk te voorzien.

Tabel 4.8

Percentage werkenden per opleidingsniveau dat werkzaam is in functies waarin het werk fysiek belastend is, verbijzonderd naar de verschillende beroepsterreinen in 1997 en 2002

\begin{tabular}{lrrrrrr} 
& \multicolumn{2}{c}{ vakspecifiek } & \multicolumn{2}{c}{ overig } & \multicolumn{2}{c}{ totaal } \\
Opleidingsniveau & 1997 & $\mathbf{2 0 0 2}$ & $\mathbf{1 9 9 7}$ & $\mathbf{2 0 0 2}$ & $\mathbf{1 9 9 7}$ & $\mathbf{2 0 0 2}$ \\
& $\%$ & $\%$ & $\%$ & $\%$ & $\%$ & $\%$ \\
Basisonderwijs & 87 & 88 & 64 & 62 & 67 & 64 \\
VBO, MAVO & 79 & 76 & 48 & 47 & 55 & 54 \\
MBO/LLW, HAVO/NWO & 48 & 48 & 33 & 32 & 39 & 38 \\
HBO & 16 & 16 & 15 & 15 & 15 & 15 \\
WO & 2 & 2 & 6 & 6 & 4 & 4
\end{tabular}

Bron: ROA

\subsection{Structurele aanpassingen en mogelijkheden voor beleid}

In de vorige paragraf is ingegaan op de te verwachten gevolgen van de verschuivingen in de vraag en de verwachte aanpassingsprocessen op de arbeidsmarkt die voontvloeien uit de discrepanties tussen vraag en aanbod. In reactie op deze discrepanties zal een marktmechanisme in werking treden waardoor arbeidskrachten met een opleidingsachtergrond waarvoor aanbodtekorten worden verwacht moeilijker geworven kunnen worden en daardoor steeds meer ingezet worden op die plaatsen waar hun specifieke opleiding het grootste belang heeft voor de functie. Zij gaan dus met name werken in functies warvoor de werkgevers geen goede alternatieven heblen. Personen met een opleidingsachtergrond watrvor alanboloverschotten worken verwacht zullen omgekeerd concessies moeten doen alan het werk dat zij krijgen en zullen daardoor vaker genoegen moeten nemen met een functie op een lager niveau dan de gevolgde opleiding. een lagere beloning of tijdelijk in plaats van vast werk. Doordat hel vor werkgevers makkelijker of goedkoper wordt werknemers met de\% opleidings-

$1^{-}$Zie L. Borghans. A. de Grip. W. Smits, H. Zuurbier. Het beroependemein van opleidingen. Re A R 1997 2. Maastricht. 1997. 
achtergrond te werven zullen zij vaker worden ingezet in functies waarin juist wel goede substitutiemogelijkheden bestaan.

Dergelijke arbeidsmarktmechanismen leiden er dus toe dat de arbeidsmarkt zich zoveel mogelijk aanpast aan de geconstateerde discrepanties. Werkgevers proberen de gevolgen van aanbodtekorten voor hun bedrijfsvoering zo veel mogelijk te reduceren, terwijl werknemers de consequenties van een slechte arbeidsmarktpositie proberen te vermijden. Hoewel een groot deel van de arbeidsmarktdiscrepanties vanwege dergelijke aanpassingsprocessen worden 'opgelost', betekenen dergelijke aanpassingen niet dat de discrepanties geen probleem meer opleveren. Werkgevers zullen immers extra kosten maken in de vorm van hogere salarissen en hogere wervingskosten, wanneer zij personeel uit een opleidingstype met aanbodtekorten blijven werven, terwijl werkgevers die uitwijken naar personeel met een andere opleidingsachtergrond geconfronteerd zullen worden met een lagere productiviteit van hun personeel of aanvullende trainingskosten moeten maken om de kennis en vaardigheden van deze werknemers aan te passen aan de eisen die de functie stelt. Aan de aanbodkant zullen degenen die een opleiding hebben gevolgd waarvoor er een aanbodoverschot bestaat, geconfronteerd worden met een lager salaris of een tijdelijk contract in plaats van een vaste aanstelling. In het geval dat ze uit moeten wijken naar een andere functie, kan daarnaast de tevredenheid met de verworven positie minder zijn. De studiekeuze zal immers mede gebaseerd zijn geweest op een voorkeur voor bepaalde beroepen, die achteraf niet verwezenlijkt wordt.

Bij een aanbodoverschot heeft de werkgever de voordelen, terwijl de werknemer de nadelen ondervindt. Omgekeerd zijn bij een aanbodtekort de nadelige gevolgen voor de werkgever en heeft de werknemer voordeel van de situatie. De kosten van de verliezende partij blijken echter altijd hoger te zijn dan de baten van de partij die voordeel uit de discrepantie haalt ${ }^{\text {IA }}$. Ofschoon de gevolgen van vraag-aanbod-discrepanties dus niet altijd duidelijk zichtbaar zijn in de vorm van een hoge werkloosheid of openstaande vacatures, wijzen ook de meer verborgen gevolgen op een gebrekkige aansluiting tussen onderwijs en arbeidsmarkt.

Dor tijclig te anticiperen op dergelijke discrepanties tussen vraag en aanbod kunnen deze nadelige gevolgen in belangrijke mate worden vermeden. In deze paragraaf zal daarom, in aanvulling op de analyse van de gevolgen van de arbeidsmarktdiscrepanties op de korte termijn, zoals die in de vorige paragraaf zijn beschreven, worden ingegaan op de mogelijke structurele anpassingen op de arbeidsmarkt die vraag en aanbod dichter bij elkaar zouden kunnen brengen. Er wordt achtereenvolgens ingegaan op:

- verschuivingen in het studiekeuzegedrag van leerlingen;

- veranderingen in de gemiddelde werkweek om zo het aanbod in volume aan te passen a a de vratag:

- veranderingen in de participatiegraad;

- verschuivingen in de structuur van de vaag die tot stand komen doordat bepaalde bedrijtssectoren zich sneller ontwikkelen dan andere.

Is Zie L. Borghans, Edtreational Choice and Labour. Market Information, Rijksuniversiteit Limburg. Matistricht, 1093 
Net als bij de aanpassingen op de arbeidsmarkt die een reactie vormen op bestaande vraag-aanbod-discrepanties, kunnen economische krachten ook dergelijke structurele verschuivingen tot stand brengen. Zo zal een langdurige slechte arbeidsmarktpositie voor een bepaald opleidingstype veelal leiden tot een verminderde instroom van leerlingen. Verder zal een aanhoudend tekort voor een bepaald opleidingstype vaak een positieve invloed hebben op de participatie, doordat de drempel om te gaan werken lager wordt. Dergelijke veranderingen komen echter veelal traag op gang en bovendien is in een aantal gevallen de invloed op de arbeidsmarktsituatie pas na enkele jaren voelbaar. Zo duurt het vier à vijf jaar alvorens een verschuiving in het keuzegedrag van leerlingen tot verschuivingen in de instroom op de arbeidsmarkt leidt. Ook zullen de feitelijke verschuivingen in de vraag op de arbeidsmarkt pas lange tijd nadat bepaalde investeringsbeslissingen bij werkgevers plaatsvonden, ontstaan. Hoewel langdurige grote discrepanties tussen vraag en aanbod uiteindelijk wel tot dergelijke structurele aanpassingen zullen leiden, ontstaat er door deze vertragingen in het aanpassingsproces ruimte voor beleid. Bovendien kunnen bepaalde aanpassingsprocessen, bijvoorbeeld het verloren gaan van hoogwaardige werkgelegenheid, maatschappelijk als ongewenst worden beschouwd. Door een afweging van de verschillende wijzen waarop structurele verschuivingen op de arbeidsmarkt vraag en aanbod dichter bij elkaar kunnen brengen, zou sturing kunnen worden gegeven aan het aanpassingsproces.

Dergelijke verschuivingen hebben, zoals hierboven werd opgemerkt, vaak pas na enige tijd een voelbare invloed op de ontwikkelingen op de arbeidsmarkt. Om een indruk te kunnen krijgen van de ernst van de verwachte arbeidsmarktdiscrepanties en de omvang van de structurele aanpassingen die vereist zijn om vraag en aanbod met elkaar in evenwicht te brengen, worden in deze paragraaf echter analyses uitgevoerd waarin er vanuit wordt gegaan dat deze aanpassingen nog een volledige doorwerking in de periode 1997-2002 zullen hebben.

\section{De studiekeuze}

Aan de aanbodzijde van de arbeidsmarkt is uiteratard de studiekeuzevoorlichting cen van de belangrijkste instrumenten om arbeidsmarktdiscrepanties te voorkomen. Ondat het doorgaans vier tot viff jaar duurt voordat een leerling, die een bepaalde richting in het onderwijs is ingeslagen, instroomt op de arbeidsmarkt, vraagt een dergelijke alanpassing om een adequate anticipatie van de toekomstige ontwikkelingen op de arbeidsmarkt. Om die reden worden in dit rapport ook middellange-termijn-prognoses gepresenteerd. Als leerlingen tijdig inzicht krijgen in de arbeidsmarktperspectieven van de verschillende opleidingen, mag een zekere aanpassing in het keuzegedrag verwacht worden.

De arbeidsmarktperspectieven zullen echter niet de enige determinant zijn van de studiekeuze van leerlingen. Naast de arbeidsmarktperspectieven zullen immers ook de capaciteiten en de voorkeuren van de leerlingen vanzelfsprekend een belangrijke rol spelen bij de keuze voor een bepaalde opleiding ${ }^{13}$. Bij een zorgvuldig tot stand geko-

19) Zie bijvoorbeeld H. Oosterbeck en D. Webbink, Enrolment in Higher Education in the Netherlands. De Economist, wol. 143. 1995. pp. 367-380 en F.J.T.A. Willems en A de Grip, fongeren en lechniek. Beleidsstudies Technologie Economie 26. Ministerie van Economische Zaken. Den Hatg. 1993. 
men studiekeuze zal daarom een afweging van interesse, mogelijkheden en perspectieven tot de uiteindelijke keuze leiden. De consequentie hiervan is dat een verslechtering van het arbeidsmarktperspectief voor een bepaald opleidingstype niet zal leiden tot een gedragsverandering bij alle leerlingen die deze opleiding zouden willen gaan volgen. Ook hoeft hun alternatief niet vanzelfsprekend de opleiding met de meest gunstige perspectieven te zijn. Voor een groot deel van de leerlingen zal immers, ondanks het verschil in arbeidsmarktperspectief, de gekozen opleiding nog steeds het meest aantrekkelijk zijn. Interesse en capaciteiten wegen in dat geval sterker. Daarnaast zullen leerlingen, vanwege hun voorkeuren en capaciteiten, met bepaalde uitwijkmogeligheden meer affiniteit hebben dan met andere.

Het is daarom van belang inzicht te hebben in de alternatieven die leerlingen bij hun studiekeuze overwegen. Figur 4.2 geeft een beeld van deze keuzemogelijkheden binnen het MBO/leerlingwezen. Daarbij zijn de opleidingstypen die vanuit een studiekeuze-optiek dicht bij elkaar liggen zoveel mogelijk bij elkaar gesitueerd en met elkaar verbonden. Omdat er geen gegevens beschikbaar zijn over de alternatieven die leerlingen overwogen bij hun feitelijke opleidingskeuze, is de figuur gebaseerd op gegevens over de opleidingstypen waarvan schoolverlaters achteraf aangaven dat ze deze opleiding liever hadden gevolgd ${ }^{20}$. Aangenomen mag worden dat deze informatie echter ook een redelijk beeld geeft van de opleidingen die bij de studiekeuze als alternatieven fungeren voor het desbetreffende opleidingstype.

De betekenis van de relatie tussen de verschillende opleidingstypen, zoals die is aangegeven in figuur 4.2, is dat als opleidingstypen die dicht bij elkaar liggen vergelijkbare arbeidsmarktperspectieven hebben, veranderingen in de studiekeuze relatief weinig mogelijkheden bieden om het arbeidsmarktperspectief te verbeteren. Een overstap naar een geheel andere positie op deze opleidingenkaart zou immers voor de meeste leerlingen te ver buiten hun interesse- en competentiesfeer liggen. Zo kan het zijn dat voor sommige leerlingen de keuze voor een opleiding met redelijke arbeidsmarktperspectieven binnen een qua interesse en capaciteiten beperkt keuzedomein, qua arbeidsmarkiperspectieven de beste keuze is, omdat de perspectieven voor de andere opleidingen binnen dit keuzedomein slechter zijn.

De figuur laat zien dat er inderdaad een dergelijke structuur in de arbeidsmarktperspectieven te ontdekken is. Er zijn op het MBO/leerlingwezen-niveau drie clusters te onderscheiden. Binnen die clusters worden relatief vaak twee opleidingen als een alternaticve keuze gezien. Deze clusters zijn respectievelijk van boven naar beneden medisch-verzorgend, economisch-administratief en technisch. In een aantal gevallen worden overigens ook twee opleidingen uit verschillende clusters als alternatieven bij de opleidingskeuze gezien. MBO/LLW handel, MBO/LLW administratie en HAVO/VWO worden vanuit veel onderling sterk verschillende opleidingstypen als een alternatief voor de studiekeuze gezien. Opmerkelijk is bijvoorbeeld de relatie tussen $M B O / L L W$ betweging en therapie en MBO/LLW elektrotechniek. De perspectieven bij de medische en verzorgende opleidingen op MBO-niveau en ook de perspectieven van de opleidingstypen in het economisch-administratief cluster zijn over het algemeen minder gun-

20 Dèe informatic is athomstig uit de RI BS schoolverlatersenquête. 
Figuur 4.2

Relatie tussen de opleidingen op $\mathrm{MBO} /$ /eerlingwezen-niveau vanuit een studiekeuze-optiek

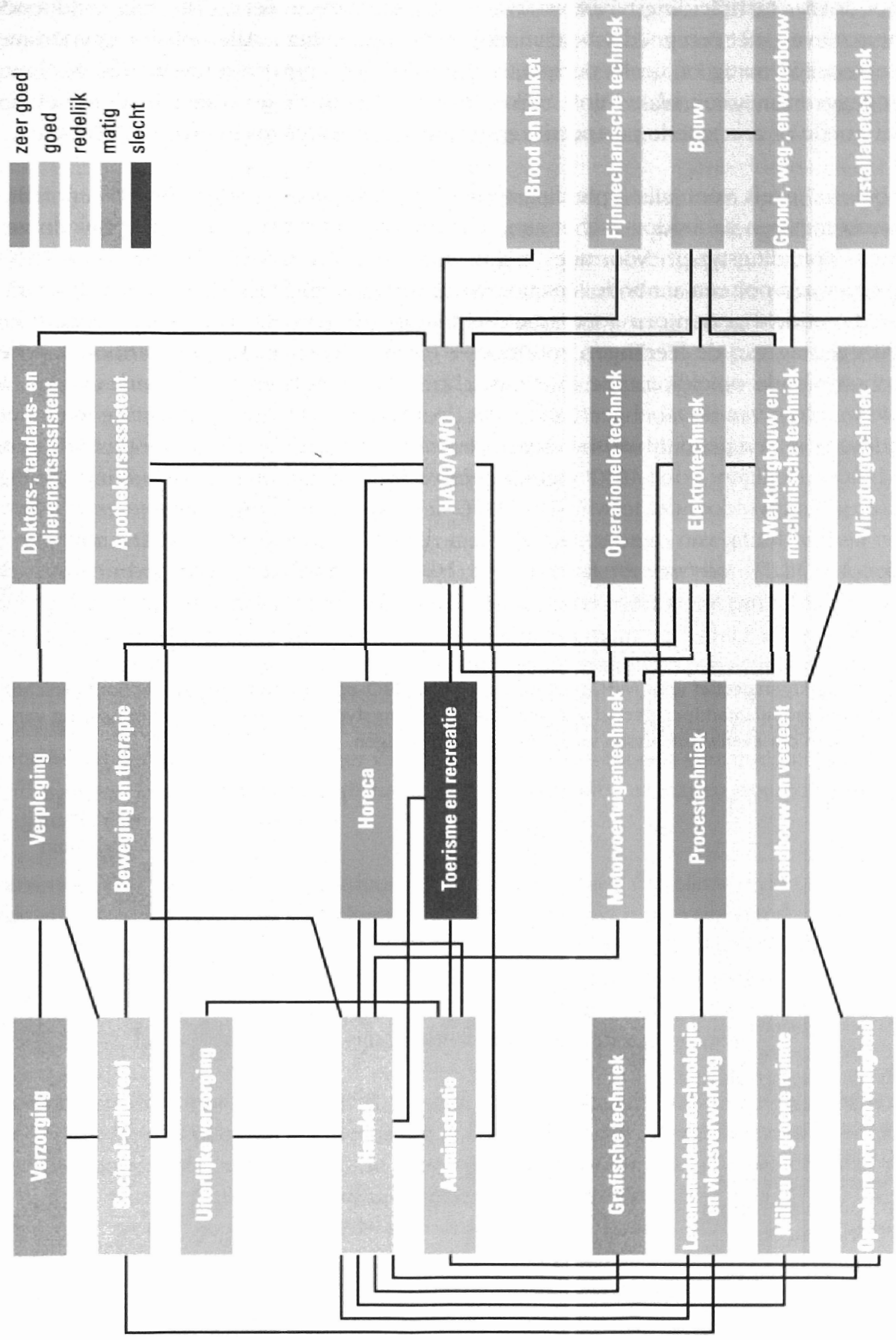


stig dan de perspectieven voor MBO/leerlingwezen-opleidingen in de technische richtingen. Dit kan een bevestiging zijn voor het vermoeden dat studiekeuze-alternatieven voor opleidingen met een minder gunstig perspectief zelf ook minder gunstige perspectieven hebben. Dit is echter niet juist. De figuur laat echter zien dat er momenteel voor de meeste opleidingstypen waarvan de perspectieven niet gunstig zijn, voldoende alternatieven met een goed arbeidsmarktperspectief bestaan. Alle opleidingstypen met een redelijk, matig of slecht perspectief op MBO/leerlingwezen-niveau (in de figuur aangegeven met een blauw-tint) blijken een alternatief bij de studiekeuze te hebben met goede of zeer goede perspectieven (in de figuur aangegeven met een geel-tint).

Tabel 4.9 geeft voor alle opleidingstypen op $\mathrm{MBO} /$ leerlingwezen-niveau en $\mathrm{HBO}$ niveau met een aanbodoverschot aan, wat het gemiddelde perspectief is van de verwante opleidingstypen. Voor alle opleidingstypen op $\mathrm{MBO} /$ leerlingwezen- en HBOniveau waarvoor een aanbodoverschot wordt verwacht blijkt dat de verwante opleidingen gemiddeld gezien een goed arbeidsmarktperspectief hebben. De mate waarin het keuzegedrag van de leerlingen zou moeten veranderen om vraag en aanbod van het desbetreffende opleidingstype in evenwicht te brengen loopt echter sterk uiteen. De laatste kolom van de tabel geeft aan welk deel van de instroom van richting moet veranderen om een goed arbeidsmarktperspectief voor het desbetreffende opleidingstype te bewerkstelligen. Voor MBO sociaal-cultureel is een minimale verschuiving van het keuzegedrag voldoende, terwijl voor $M B O / L L W$ bandel en $H B O$ toerisme en recreatie een vermindering van minder dan $10 \%$ van de instroom voldoende is. Daarentegen is voor $M B O / L L W$ loerisme en recreatie en $H B O$ personeelswerk een halvering van de instroom nog niet voldoende om vraag en aanbod weer in balans te krijgen.

Tabel 4.9

Arbeidsmarktperspectief voor $\mathrm{MBO} /$ leerlingwezen- en $\mathrm{HBO}$-opleidingen met een aanbodoverschot, gemiddeld arbeidsmarktperspectief van verwante opleidingstypen en benodigde vermindering van de instroom om evenwicht tussen vraag en aanbod te krijgen

Opleiding

\section{gemiddelde ITA \\ verwante opleidingen}

\section{benodigde \\ vermindering instroom}

$\%$
IIAVONWO

MBO/L,LW grafische techniek

MBO dokters-, tandarts-en

dierenartsassistent

MIBO socialal-cultureel

MBSOA.LW verzorging

MBO/I.IW beweging en therapie

MBO/LIW handel

MBO/LISW toerisme en recreatie

IIBO milieukunde en

levensmiddelentechnologie

HBO) commerciële economie

IIBO toerisme en recreatie

HBO) personeelswerk

Bron: ROA 
Het opleidingstype $M B O / L L W$ verpleging blijkt voor drie opleidingen met een verwacht aanbodoverschot het alternatief met het gunstigste perspectief te zijn. Ook $M B O / L L W$ elektrotechniek is voor zowel $M B O / L L W$ grafische techniek als voor $M B O / L L W$ beweging en therapie een alternatief met een goed perspectief. Voor $H A V O / V W O$ biedt dit opleidingstype eveneens een alternatief met goede perspectieven, maar $M B O / L L W$ boreca is voor $H A V O / V W O$ een alternatief met betere perspectieven. Voor wat betreft de keuze van MAVO'ers voor een HAVO/VWO- of een MBO-opleiding, is het vanzelfsprekend van groot belang in hoeverre de HAVO/VWO-opleiding eindonderwijs zal zijn. Ook voor $M B O / L L W$ handel is $M B O / L L W$ boreca het gunstigste alternatief.

Een enkel alternatief met goede perspectieven binnen een domein van opleidingstypen met minder gunstige perspectieven, biedt daarmee reeds een goede mogelijkheid voor aanpassingsprocessen in het keuzegedrag van leerlingen. Overigens zullen - als de in tabel 4.9 getraceerde verschuivingen daadwerkelijk plaatsvinden - de perspectieven voor opleidingstypen waarvoor momenteel een goed tot zeer goed arbeidsmarktperspectief wordt verwacht - zeker als het om relatief kleine opleidingen gaat - aanzienlijk kunnen veminderen. Voor $M B O / L L W$ verpleging zouden vanwege het zeer grote alanbodtekort dat voor dit opleidingstype wordt voorzien de perspectieven die thans zeer goed zijn, echter altijd nog goed blijven, hoewel de Indicator Toekomstige Arbeidsmarktperspectieven zou oplopen van 0,81 naar 0,91 .

Ook door middel van gerichte beleidsmaatregelen kan een verschuiving van de instroom in het onderwijs worden bewerkstelligd. In de eerste plaats kan natuurlijk door middel van een arbeidsmarktfixus de instroom in richtingen met minder gunstige perspectieven worden verminderd. Een dergelijk instrument ligt echter alleen voor de hand als de instroom in het onderwijs de toekomstige vraag in aanzienlijke mate overtreft $^{21}$. Een zeer restrictieve arbeidsmarktfixus leidt er immers toe dat de perspectieven voor degenen die wel worden toegelaten sterk verbeteren. Hierdoor krijgen toekomstige leerlingen geen signalen meer van de markt, die hen tot een keuzeverandering ain zullen zetten, waardoor de arbeidsmarktfixus tot in lengte van dagen noodzakelijk zou kunnen blijven.

Bovendien leidt een arbeidsmarktfixus er toe dat leerlingen die niet worden toegelaten een alternatieve opleiding zullen kiezen. Als de alternatieven die voor handen zijn geen betere perspectieven bieden dan de opleiding warrvor de fixus wordt ingestedd, dan leidt de verbeterde situatie bij een opleiding tot een toename van de problemen bij andere opleidingen. Een eventueel in te stellen arbeidsmarktfixus zou daarom altijd in het licht van het keuzegedrag in zijn totaliteit bezien moeten worden.

Ook andere instrumenten kunnen mogelijk bijdragen aan een verschuiving van de instroom van opleidingstypen met matige of slechte perspectieven naar opleidingstypen met goede perspectieven. In de eerste plaats kan hierbij gedacht worden ain het vergroten van het aantal opleidingsplaatsen waar een opleiding met goede perspectieven wordt aangeboden. Als bijvoorbeeld de opleiding MBO/LWW verpleging

21 L. Borghans. A. de Grip. Numerus fixus en de arbeidsmarkt, in: Economisch Statistische berichen. 5 februari 1997, vol. 82. no. 4092. p. $111-113$. 
wordt aangeboden aan alle instellingen waar ook de andere medische en verzorgende opleidingen worden aangeboden kan in ieder geval vermeden worden dat geografische restricties de instroom van een dergelijke opleiding beperken. In de tweede plaats zal het in een aantal gevallen mogelijk zijn om nieuwe opleidingsrichtingen aan te bieden die qua arbeidsmarktmogelijkheden sterk overeenkomen met een opleiding met gunstige perspectieven, maar qua vereiste competenties en interessesfeer leerlingen weten aan te trekken die aanvankelijk zouden kiezen voor opleidingen met minder gunstige perspectieven. Figuur 4.2 laat zien dat voor de technische richtingen op MBO/leerlingwezen-niveau dergelijke stimulerende maatregelen veelal weinig effect zullen sorteren. Omdat voor de meeste technische opleidingstypen de arbeidsmarktperspectieven gunstig zijn, zal een verhoogde instroom bij het ene technische opleidingstype ten koste gaan van de instroom naar andere opleidingen met goede perspectieven. In dat geval is er slechts sprake van een verschuiving van de problematiek.

Beslissingen over het starten van nieuwe opleidingen om daarmee de verwachte discrepanties op de arbeidsmarkt tegen te gaan, dienen dus niet louter gebaseerd te worden op de arbeidsmarktperspectieven van de desbetreffende opleiding. Bij een dergelijke afweging dient ook de vraag betrokken te worden welke leerlingen men hiermee additioneel aan denkt te trekken. Van belang is dan welke perspectieven deze leerlingen bij hun aanvankelijke opleidingskeuze reeds hadden, en in welke mate de capaciteiten en interesses van deze leerlingen voor de in de nieuwe opleidingsrichting vereiste vaardigheden een restrictie kunnen betekenen voor de gewenste verschuiving van de instroom.

\section{Arbeidstijd}

Naast veranderingen bij de instroom van schoolverlaters op de arbeidsmarkt, kunnen structurele aanpassingen van het aanbod aan de vraag voor een bepaald opleidingstype ook tot stand komen door een verandering in de gemiddelde werktijdfactor van de reeds werkzame personen of door een wijziging in de participatiegraad.

Doordat een aanpassing van het aantal gewerkte uren per week van invloed is op het volume van het arbeidsaanbod kan een reductie van de gemiddelde werkweek voor mensen met een bepaalde opleidingsachtergrond een te hoog aanbod in balans brengen met de vraag. Omgekeerd zou een aanbodtekort bestreden kunnen worden met langere gemiddelde werkweken. Afgezien van overwerk - dat vaak op de korte termijn gebruikt zal worden ter bestrijding van problemen bij de recrutering van personeel - ligt een dergelijke toename van de gemiddelde werkweek maatschappelijk gezien niet erg voor de hand. Er zal hier dan ook met name worden ingegaan op de mogelijkheid om de perspectieven van opleidingstypen met een aanbodoverschot te verbeteren. Daarbij moet overigens wel worden bedacht dat als de arbeidsmarkt op deze wijze in evenwicht zou worden gebracht, dit de mogelijkheden ontneemt om dit aanbodoverschot via omscholing geschikt te maken voor segmenten waar sprake is van een tekortschietend aanbod.

In de literatuur is uitgebreid gediscussieerd over de vraag welke invloed een reductie van de arbeidstijd heeft op de vraag naar arbeid. Er zijn duidelijke aanwijzingen dat afhankelijk van de omvang van de functie en de wijze waarop de arbeidstijdreductie 
wordt gerealiseerd - een afname van het aantal gewerkte uren niet volledig wordt gecompenseerd door een uitbreiding van het aantal personen dat wordt aangesteld. Omdat dit hoofdstuk in de eerste plaats bedoeld is om een beeld te krijgen van de omvang van de benodigde aanpassingen op de arbeidsmarkt gezien de verwachte vraag-aanbod-discrepanties zal hier echter eenvoudigheidshalve wel worden aangenomen dat de vraag in volume-termen niet daalt als gevolg van een reductie van de werkweek.

Tabel 4.10 geeft een beeld van de veranderingen in het gemiddeld aantal gewerkte uren per week dat voor de opleidingstypen met een aanbodoverschot benodigd is om in het jaar 2002 vraag en aanbod in evenwicht te krijgen. Omdat een verandering in het gewerkte aantal uren het aanbod van alle werkenden beïnvloedt en niet alleen betrekking heeft op een verandering in het aanbod van nieuwkomers, zijn voor de meeste opleidingstypen relatief geringe veranderingen in de aanvang van de gemiddelde werkweek voldoende om het aanbod op het niveau van de vraag te krijgen. Bij de meeste

Tabel 4.10

Gemiddeld aantal gewerkte uren per week en de lengte van de gemiddelde werkweek die nodig is om vraag en aanbod in evenwicht te krijgen bij de opleidingstypen met een aanbodoverschot

Opleiding

Basisonderwijs

VBO bouwtechniek

VBO installatietechniek

VBO motorvoertuigentechniek

VBO brood en banket

VBO horeca en levensmiddelentechniek

VBO administratie, handel en textiel

$\mathrm{VBO}$ verzorging

HAVONWO

MBO/LLW grafische techniek

MBO/LLW brood en banket

MBO dokters-, tandarts- en dierenartsassistent

MBO sociaal-cultureel

$\mathrm{MBO} / \mathrm{LLW}$ verzorging

$\mathrm{MBO} / \mathrm{LLW}$ beweging en therapie

MBO/LLW handel

MBO/LLW toerisme en recreatie

HBO milieukunde en levensmiddelentechnologie

HBO commerciële economie

$\mathrm{HBO}$ toerisme en recreatie

HBO personeelswerk

Wo landbouw en milieukunde

Wo farmacie

Wo kunstwetenschappen

\section{huidig aantal \\ gemiddeld \\ gewerkte uren}

benodigd aantal uren in $\mathbf{2 0 0 2}$
36

40

39

41

41

38

33

28

35

40

42

30

32

28

32

40

36

39

40

35

37

38

42

38 
opleidingstypen met een aanbodoverschot is een reductie in de werkweek van minder dan drie uur voldoende. Voor VBO motorvoertuigentechniek, VBO brood en banket, $V B O$ boreca en levensmiddelentechniek en WO kunstwetenschappen zijn aanzienlijk grotere reducties in de werkweek vereist om een evenwicht tussen vraag en aanbod te bewerkstelligen. Bij VBO administratie, handel en textiel, MBO/LLW toerisme en recreatie en $H B O$ personeelswerk is de vereiste reductie in de gemiddelde werkweek zo fors dat het gemiddeld aantal gewerkte uren per week onder de 30 uitkomt. Bij de opleidingstypen $V B O$ verzorging en $M B O / L L W$ verzorging, waar de gemiddelde werkweek overigens reeds korter is dan 30 uur, zal daarentegen slechts een geringe reductie van de gemiddelde werkweek noodzakelijk zijn voor het in evenwicht brengen van vraag en aanbod.

Zoals reeds eerder werd opgemerkt lijkt het niet reëel om een verlenging van de werkweek te zien als een mogelijk instrument om het arbeidsaanbod te vergroten. Voor een aantal opleidingstypen zou dit - gezien de verwachte aanbodtekorten - bovendien zeer lange werkweken vereisen. Bij $M B O / L L W$ landbouw en veelteelt, $M B O / L L W$ operationele techniek, HBO landbouw en veeteelt, HBO vervoer en logistiek, $H B O$ recht en bestuur, WO bouwkunde, WO civiele techniek, WO informatica en bestuurlijke informatiekunde en WO tandheelkunde zou de werkweek in dat geval boven de 50 uur uitkomen. $\mathrm{Bij} M B O / L L W$ landbouw en veeteelt en $H B O$ landbouw en veeteelt wordt dit mede veroorzaakt doordat hier thans reeds zeer lange werkweken worden gemaakt van respectievelijk 49 en 47 uur. Bij WO accountancy en belastingen zou als door middel van een uitbreiding van de werkweek het arbeidsaanbod aangepast zou worden aan de vraag, een toename van de gemiddelde werkweek van 43 uur op dit moment naar 64 uur per week in 2002 vereist zijn.

\section{Participatie}

Bij de prognoses van de arbeidsmarktperspectieven per opleidingstype wordt verondersteld dat personen die reeds langer dan een jaar werkloos zijn geen direct inzetbaar arbeidsaanbod zijn en derhalve niet concurreren met de schoolverlaters die dezelfde opleidingsachtergrond hebben. Wanneer er sprake is van alanbodtekorten kunnen voor deze langdurig werklozen de mogelijkheden om een baan te krijgen echter verbeteren. Bovendien is er bij de meeste opleidingen ook een aanzienlijke groep personen tussen de 15 en 65 jaar die zich niet aanbiedt op de arbeidsmarkt, terwijl ook geen dagonderwijs wordt gevolgd. Gedeeltelijk bestaat deze groep uit mensen die niet willen werken en arbeidsongeschikten die niet kunnen werken. Anderzijds kan een deel van de nietparticiperenden als een zogenaamde 'stille reserve' worden beschouwd. Aanbodtekorten en de datrmee gepaard gaande problemen bij de recrutering van personeel kunnen er toe leiden dat er een verhoogde aantrekkingskracht op deze personen wordt uitgeoefend. De drempel naar de arbeidsmarkt wordt wellicht lager doordat het eenvoudiger wordt werk te vinden, terwijl werkgevers daarnalst wellicht de arbeidsvoorwaarden met name voor deze herintreders gunstiger maken en bereid zijn in de eventueel vereiste bijscholing voor deze herintreders te investeren.

Nagegaan zal worden in hoeverre langdurig werklozen en de stille reserve van non-participanten op de arbeidsmarkt ingezet zouden kunnen worden on de verwachte aanbodtekorten bij een groot aantal opleidingstypen te voorkomen. Hierbij is eerst nage- 
gaan of de inzet van alle langdurig werklozen voldoende zou zijn om het aanbodtekort op te heffen. Vervolgens is voor de opleidingstypen, waarvoor de groep langdurig werklozen te klein is om de kloof tussen vraag en aanbod te dichten, onderzocht in welke mate de intrede van niet op de arbeidsmarkt participerende personen met de desbetreffende opleidingsachtergrond vraag en aanbod bij elkaar kan brengen.

In totaal zijn er 445.000 arbeidskrachten nodig om in alle aanbodtekorten te voorzien. terwijl er maar 110.000 langdurig werklozen met de juiste kwalificaties zijn. Over het geheel genomen is de inzet van langdurig werklozen derhalve volstrekt niet toereikend om het evenwicht tussen vraag en aanbod op alle arbeidsmarktsegmenten te herstellen. Tabel 4.11 geeft een overzicht van de opleidingstypen waarvoor de inzet van de langdurig werklozen wel voldoende effect zou kunnen sorteren om de discrepantie tussen vraag en aanbod op te heffen. Het gaat hier om zestal opleidingstypen waar variërend van $12 \%$ bij $H B O$ voeding tot $94 \%$ bij $H B O$ maatschappelijk werk en bulpverlening van de langdurig werklozen ingezet zou moeten worden om het evenwicht tussen vraag en aanbod te bewerkstelligen. Bij de overige opleidingstypen met een goed of zeer goed perspectief is de inzet van alle langdurig werklozen niet voldoende om in het gevratagde aanbod te voorzien.

Tabel 4.11

\section{Opleidingstypen waarbij de verwachte aanbodtekorten opgelost kunnen worden door langdurig} werklozen in te schakelen

Opleiding

VBO mechanische techniek

MBO/LLW levensmiddelentechniek/vleesverwerking

HBO lerarenopleiding expressie

$\mathrm{HBO}$ voeding

HBO maatschappelijk werk en hulpverlening

Bron: ROA

Tabel 4.12 laat zien bij welke opleidingstypen in aanvulling op deze inzet van langdurig werklozen het evenwicht tussen vraag en aanbod hersteld kan worden door een afname van het percentage niet-participerenden met de desbetreffende opleidingsachtergrond. Bij een aantal opleidingstypen zoals MAVO, VBO landbouw' en naturtijke omgeving, MBO/LLW installatietechniek, MBO/LIW apotbekersassistent, IIBO communicatie en journalistiek en WO werktuigbouwkunde is een betrekkelijke geringe verhoging van de participatiegraad voldoende om de arbeidsmarkt voor het destetreffende opleidingstype in balans te krijgen. Voor een groot antal van de in de tabet genoemde opleidingstypen zou echter meer dan de helft van de nict-participerenden met de deshetreffende opleidingsachtergrond zich moeten aanbieden op de arbeidsmarkt. Een dergelijke hoge arbeidsmarktintrede is vereist bij de opleidingstypen VB() elektrotechniek, MBO/LLW landbotuw en veeteelt, MBO/LLW installatietechniek, MBO) openbare orde en veiligheid, HBO (fysiontherapie, HBO accountancy en bedrifsecone, mie, $H B O$ bedrijfskunde, HBO openbare orde en veiligheid en WO u'iskunde' en 
Tabel 4.12

Opleidingstypen waarbij de verwachte aanbodtekorten opgelost kunnen worden door het inschakelen van de niet-participerenden

Opleiding

MAVO

VBO landbouw en natuurlijke omgeving

vBO fijnmechanische techniek

VBO elektrotechniek

VBO vervoer

MBO/LLW landbouw en veeteelt

MBO/LLW milieu en groene ruimte

MBO/LLW laboratorium

MBO/LLW installatietechniek

MBO/LLW werktuigbouw en mechanische

techniek

MBO/LLW fijnmechanische techniek

MBO/LLW vliegtuigtechniek

MBO/LLW elektrotechniek

MBO/LIW vervoer

MBO/LLW apothekersassistent

MBO/LLW verpleging

MBO/LLW uiterlijke verzorging

MBO/LLW horeca

MBO/LLW administratie

MBO/LLW secretariaat

MBO openbare orde en veiligheid

HBO lerarenopleiding basisonderwijs

HBO lerarenopleiding talen

HBO lerarenopleiding natuur en techniek

HBO lerarenopleiding economie en

maatschappii

HBO lerarenopleiding lichamelijke opvoeding

HBO lerarenopleiding medisch en verzorging

IIBO tolk en vertaler

HBO laboratorium

IIBO elektrotechniek

HBO (fysio)therapie

HBO accountancy en bedriffseconomie

IIBO secretariaat

IIBO bedrijfskunde

IHBO conmunicattie en journalistiek

IIBO bibliotheek en documentatie

HIBO nitvoerende en beeldende kunsten

HIBO openbare orde en veiligheid

Wo letteren

Wo wiskunde en nattuurwetenschappen

Wo werktuigbouwkunde

Wo (dier) geneeskunde

Wo rechten en bestuurskunde

wo sociale wetenschippen

\section{huidige non-participatie}

$\%$

41

20

$-$

10

10

10

-

21

12

13

16

-

9

13

32

34

36

17

20

34

16

27

20

13

18

18

35

37

21

10

16

9

22

6

16

21

12

12

8

7

7

8

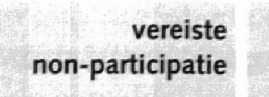

$\%$

41

19

-

5

6

3

$-$

19

3

9

11

-

1

8

31

19

29

2

18

26

4

16

10

0

3

15

27

28

18

2

8

3

13

3

-

8

16

-

9

3

-

4

6 vereiste

vermindering

non-participatie

$\%$

0

1

10

51

43

71

43

7

71

27

33

44

85

42

1

44

21

91

9

22

72

41

48

97

83

16

24

23

13

82

53

63

42

54

1

48

21

56

24

56

6

44

18

46

Bron: ROA 
natuurwetenschappen, terwijl voor $M B O / L L W$ elektrotechniek, MBO/LLW boreca, HBO lerarenopleiding natuur en techniek, HBO lerarenopleiding economie en maatschappij, HBO elektrotechniek, HBO vervoer en logistiek en $H B O$ verpleegkunde zelfs een intrede van meer dan $80 \%$ van de niet-participerende potentiële beroepsbevolking vereist is. Het valt niet te verwachten dat een dergelijk sterke mate van herintreding verwezenlijkt zou kunnen worden.

Tabel 4.13 laat echter in aanvulling hierop zien dat voor nog eens 24 opleidingstypen zelfs een volledige inzet van de niet-participerenden onder de 65 jaar onvoldoende zou zijn om het aanbod op het niveau van de vraag te krijgen. Het betreft hier een opleiding op VBO-niveau, vijf opleidingen op MBO/LLW-niveau en maar liefst negen opleidingen op HBO-niveau en negen opleidingen op WO-niveau. Voor een aantal van deze richtingen is een veelvoud van de beschikbare non-participanten vereist. Voor WO informatica en bestuurlijke informatiekunde - dat vanwege zijn leeftijdsopbouw een lage non-participatie kent - zou het inschakelen van niet-participerenden niet meer zijn dan een druppel op een gloeiende plaat.

Tabel 4.13

Opleidingstypen waarbij de aanbodtekorten niet opgelost kunnen worden

\section{Opleiding}

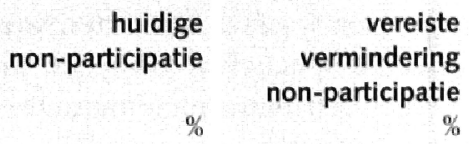

huidige non-participatie

$\%$

vermindering non-participatie

VBO beveiliging
MBO/LLW bouw
MBO/LLW grond-, weg- en waterbouw
MBO/LLW motorvoertuigentechniek
MBO/LLW operationele techniek
MBO/LLW procestechniek
HBO landbouw en veeteelt
HBO bouwkunde
HBO civiele techniek
HBO werktuigbouwkunde
HBO informatica
HBO chemische technologie
HBO vervoer en logistiek
HBO verpleegkunde
HBO recht en bestuur
WO theologie
WO bouwkunde
WO civiele techniek
WO elektrotechniek
WO informatica en bestuurlijke informatiekunde
WO tandheelkunde
WO econom(etr)ie
WO bedrijfskunde
WO accountancy en belastingen

194

$13-118$

$9 \quad 117$

$9 \quad 111$

- 226

- 368

$\begin{array}{ll}- & 239\end{array}$

$-240$

207

649

138

$16 \quad 102$

$14 \quad 106$

547

127

668

684

347

20.006

531

244

1.423

1.027

Bron: ROA 
De hierboven besproken structurele aanpassingen op de arbeidsmarkt die kunnen dienen om vraag en aanbod voor de verschillende opleidingstypen met elkaar in evenwicht te brengen hadden allemaal betrekking op de aanbodzijde van de arbeidsmarkt. Het is echter ook denkbaar dat ontwikkelingen aan de vraagzijde van de arbeidsmarkt de discrepanties tussen vraag en aanbod verkleinen. Een dergelijke verschuiving kan optreden wanneer bedrijfssectoren die sterk gehinderd worden door recruteringsproblemen, minder groeien dan bedrijfssectoren die minder met problemen in de personeelsvoorziening worden geconfronteerd, of wanneer het beleid stimulerende maatregelen neemt die de werkgelegenheid bevorderen in bedriifssectoren waar met name personen met minder gunstige arbeidsmarktperspectieven emplooi kunnen vinden.

Een toename van de werkgelegenheid in een bepaalde bedrijfssector zal vanzelfsprekend voor alle opleidingstypen die in deze sector vertegenwoordigd zijn een verbetering van het perspectief betekenen. De discrepanties tussen vraag en aanbod op de arbeidsmarkt zullen afnemen, als de werkgelegenheid groeit in de bedrijfssectoren waarin relatief veel werkgelegenheid bestaat voor mensen met een opleidingsachtergrond waarvoor een redelijk, matig of slecht perspectief wordt verwacht. In dat geval nemen de overschotten immers sneller af, dan de tekorten toenemen. Daarentegen zullen de knelpunten in de personeelsvoorziening groter worden als de werkgelegenheid zou toenemen in een bedriffssector waarin relatief veel mensen werkzaam zijn met een opleiding waarvoor tekorten worden verwacht. Vanwege de huidige gunstige arbeidsmarktperspectieven voor een groot aantal opleidingstypen heeft echter $66 \%$ van de werkenden een opleidingsachtergrond met een goed of zeer goed perspectief, 34\% heeft daarentegen een redelijk, matig of slecht perspectief. Hierdoor zullen slechts in weinig bedrijfssectoren meer arbeidskrachten met een redelijk, matig of slecht arbeidsmarktperspectief werkzaam zijn dan met een gunstig perspectief.

Taluel 4.14 laat zien wat het effect is van een groei van de werkgelegenheid in de verschillende bedriffssectoren op de alanshitingsproblematiek tussen vraag en aanbod op de arbeidsmarkt. De tabel geeft per bedriffssector een overzicht van de verhouding van de verbetering van het arbeidsmarktperspectief tussen de opleidingen met een aanbodoverschot en de opleidingen met een atanbodtekort. Wanneer deze ratio groter is dan I leidt een toename van de werkgelegenheid in de desbetreffende bedrijfssector per saldo tot een verbetering van de atansluiting tussen vraig en aanbod op de arbeidsmarkt. Dit is alleen het geval in de sectoren thees-en visterwerking, oterige voedingsproducten, textiel. hout- en boummaterialen, grafische industrie en de horeca. Dat betekent dat het met name deze sectoren zijn warvoor een extra stimulans vooral een werkgelegenheidsgroei zou kunnen opleveren voor degenen die thans minder gunstige arbeidsmarktperspectieven hebben. Ongekeerd geld voor de basiscbemie, metaalproducten, energie, onderwijs en orerbeid dat een algehele groei van de werkgelegenheid in deze sectoren met name extra vratag zou impliceren naar opleidingstypen waarvoor reeds grote wervingsproblemen worden verwacht. 
Tabel 4.14

Effect op de Indicator Toekomstige Arbeidsmarktperspectieven (ITA) bij een groei van de werkgelegenheid op de aansluitingsproblematiek tussen vraag en aanbod

ratio*

Tuinbouw

0,76

Veehouderij

0,44

Akkerbouw, bosbouw en visserij

0,43

Vlees- en visverwerking

1,52

Overige voedingsproducten

1,27

Drank en tabaksproducten

0,85

Basischemie

0,28

Eindproducten chemie

0,43

Kunststofverwerking

0,85

Basismetaal

0,57

Metaalproducten

Machine-industrie

0,92

0,26

0,48

0,43

Transportmiddelen

2,56

Textiel

1,02

Hout- en bouwmaterialen

0,95

Papier

1,35

0,25

0,58

Bouw

0,57

0,70

0,68

0,78

0,89

0,76

0,64

1,45

0,82

0,56

0.74

0,68

0.46

0,11

0,33

Overheid

* verhouding van de verbetering van het arbeidsmarktperspectief tussen de opleidingen met een aanbodoverschot en de opleidingen met een aanbodtekort 


\section{Besluit: veranderende perspectieven op de arbeidsmarkt}

In de voorgaande hoofdstukken is een overzicht gegeven van de ontwikkelingen die zich naar verwachting de komende viff jaar voor zullen doen op de arbeidsmarkt. Op basis van deze ontwikkelingen is een beeld geschetst van de arbeidsmarktperspectieven voor schoolverlaters en de te verwachten knelpunten in de personeelsvoorziening voor de periode 1997-2002. In aanvulling hierop is informatie gepresenteerd over de actuele arbeidsmarktsituatie en de structurele positie die opleidingstypen innemen op de arbeidsmarkt.

De ontwikkelingen op de arbeidsmarkt zoals die voor de komende viff jaar worden verwacht, wijzen op een sterke omslag in de arbeidsmarktsituatie in de loop van de jaren negentig, die deels in de actuele arbeidsmarktsituatie reeds tot uiting komt. De economische groei is de laatste jaren voorspoedig te noemen, waardoor de werkgelegenheid aanzienlijk groeit. Daarnaast blijft door de vergrijzing de vervangingsvraag - die toch al de omvangrijkste component van de vraag naar nieuwkomers was - de komende tijd toenemen. Aan de aanbodkant leidt de ontgroening daarentegen tot een sterke afname van het aantal schoolverlaters dat de komende jaren tot de arbeidsmarkt zal toetreden.

Tabel 5.1 toont op duidelijke wijze de omwenteling die de arbeidsmarkt in tien jatar tijd doormaakt. In de tabel wordt een vergelijking gemaakt van arbeidsmarktperspectieven voor schoolverlaters op grond van de an het eind van de jaren tachtig door het ROA opgestelde prognoses voor $1992^{22}$ en de huidige prognoses voor het jaar 2002. In 2002 wordt voor $89 \%$ van de schoolverlaters een goed of zeer goed perspectief verwacht, terwijl dit percentage bij de prognoses voor 1992 slechts 16\% was. Aan de andere kant kende maar liefst $83 \%$ van de schoolverlaters in het begin van de jaren negentig matige tot slechte perspectieven, terwijl dat thans nog slechts $4 \%$ betreft.

Tabel 5.1

Arbeidsmarktperspectieven voor schoolverlaters volgens de ROA-prognoses voor 1992 en 2002

Typering

1992

2002

Zeer goed

Goed

Redelijk

Matig

Slecht

04

Bron: ROA

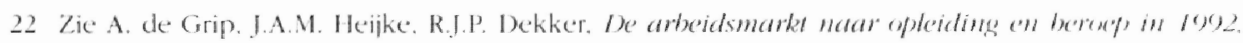
ROA-R-1989 \&, Maastricht, 1989). Om een zo goed mogelijke vergelijking te maken tussen lexide. prognoses is de Indicator Toekomstige Arbeidsmarktperspectieven bij de prognoses van Ige) 2 atangepast aan de bij de prognoses voor 2002 gehanteerde berekeningswijze. 
Deze veranderende perspectieven op de arbeidsmarkt hebben grote invloed op de wijze waarop ontwikkelingen in de aansluiting tussen onderwijs en arbeidsmarkt gevolgd zullen worden. Bekommernissen over de arbeidsmarktmogelijkheden van schoolverlaters zullen plaats maken voor analyses van de wervingsproblematiek bij bedrijven. Toch zijn de verwachte ontwikkelingen minder uniform dan dit macrobeeld suggereert. Als men inzoomt op de arbeidsmarktontwikkelingen van de afzonderlijke opleidingstypen en de achterliggende ontwikkelingen nader analyseert, blijken de arbeidsmarktperspectieven toch sterk uiteen te lopen tussen de verschillende opleidingstypen. Op ieder opleidingsniveau zijn er nog steeds zowel opleidingstypen met gunstige, als opleidingstypen met minder gunstige arbeidsmarktperspectieven te vinden. Verder kent de Nederlandse arbeidsmarkt, structureel gezien, sterkere en zwakkere plekken en zijn er, met name aan de onderkant van de arbeidsmarkt, nog steeds groepen die ondanks de verbeterende arbeidsmarktperspectieven een zwakke positie op de arbeidsmarkt blijven innemen.

Dit gevarieerde beeld van de arbeidsmarkt blijkt zowel vanuit individueel als vanuit beleidsmatig perspectief diverse aanknopingspunten te bieden om te werken aan een verbeterde aansluiting tussen onderwijs en arbeidsmarkt. In dit hoofdstuk zullen de in het rapport weergegeven ontwikkelingen op de arbeidsmarkt worden belicht vanuit een aantal van deze beleidsmatige invalshoeken. Daarbij gaat het achtereenvolgens om:

- knelpunten in de personeelsvoorziening;

- de onderkant van de arbeidsmarkt;

- de arbeidsmarktperspectieven van allochtonen;

- hoge arbeidsmarktinstroom en slechte arbeidsmarktperspectieven;

- veranderingen in het onderwijsaanbod en macrodoelmatigheid;

- scholingsbeleid.

\section{Knelpunten in de personeelsvoorziening}

Bij de twee jaar geleden opgestelde prognoses voor de periode 1995-2000 werd reeds duidelijk dat voor het HBO en het wetenschappelijk onderwijs het op dat moment heersende beeld van veel te grote aantallen afgestudeerden die steeds vaker met banen onder hun niveau genoegen moesten nemen en op deze wijze de lager opgeleiden uit hun functies verdrongen, zijn geldingskracht zou gaan verliezen. Als gevolg van de stagnerende deelname aan het hoger onderwijs enerzijds en de zich voortzettende groei van de vraag naar HBO'ers en met name WO'ers anderzijds, werd reeds toen een duidelijke omslag voor de hoger opgeleiden op de arbeidsmarkt voorzien. De recente problemen bij de werving van personeel voor de informaticabranche zijn een duidelijk voorbeeld van het feit dat deze omslag thans reeds werkelijkheid is geworden. De verwachte verdere toename van de vraag - zowel de uitbreidingsvraag als de vervangingsvraag - en de verdere afname van de instroom van schoolverlaters, leiden er toe dat inmiddels ook voor een groot aantal opleidingstypen op MBO-niveau problemen in de personeelsvoorziening worden verwacht.

23 Researcheentrum voor Onderwijs en Arbeidsmarkt. De arbeidsmarkt naar opleiding en beroep tot 2000, ROA-R-1995/3, Maastricht, 1995. 
Zoals in hoofdstuk 3 is aangegeven, komen in vrijwel alle bedrijfssectoren opleidingstypen voor waarbij naar verwachting problemen bij de recrutering zullen ontstaan ${ }^{24}$. Bij een tiental opleidingstypen zijn de knelpunten erg groot. Als hiervoor in de vraag zou moeten worden voorzien door een toenemende omvang van de werkweek, zou er gemiddeld meer dan 50 uur - en voor WO accountancy en belastingen zelfs meer dan 60 uur - gewerkt moeten worden. Een dergelijke optie biedt uiteraard geen reëel perspectief voor het verlichten van de knelpunten in de personeelsvoorziening. Het stimuleren van de arbeidsmarktparticipatie van mensen met de desbetreffende opleidingsachtergrond zou een alternatief kunnen vormen warmee voorzien zou kunnen worden in de personeelsbehoefte van werkgevers. Voor een 24-tal opleidingstypen blijkt echter zelfs een volledige inzet van de potentiële beroepsbevolking met de deshetreffende opleidingsachtergrond onvoldoende te zijn om in de vraag te voorzien. Voor nog eens 12 opleidingstypen zou de non-participatie met meer dan de helft moeten worden teruggebracht.

Als echter de vraagkant van de arbeidsmarkt zich aan zou moeten passen aan de verwachte discrepanties tussen vraag en aanbod, zouden alle sectoren hun vraag moeten reduceren. Alleen de bedriffssectoren vlees- en visverwerking, overige voedingsproducten, textiel, hout- en bouwmaterialen, grafische industrie en de boreca doen per saldo, een sterker beroep op de opleidingstypen met een redelijk, matig of slecht perspectief dan op opleidingstypen met een goed of zeer goed perspectief. Een dergelijke rem op de werkgelegenheidsgroei is ook geen bevredigend alternatief. Als men echter wil vermijden dat de sectorale werkgelegenheidsontwikkeling zich aan dient te passen aan de verwachte personeelstekorten voor diverse opleidingstypen, kan niet volledig worden teruggevallen op de genoemde toename van de werktijd of toename van de participatiegraad. Deze bieden onvoldoende rek om in de tekorten te voorzien. Voor een volledige oplossing van de knelpunten in de personeelswerving zouden dan ook scholingsinspanningen vereist zijn die tot stand komen door ofwel verschuivingen in het studiekeuzegedrag van jongeren ofwel een toename van de activiteiten op het gebied van om- of bijscholing. Aan het eind van dit hoofdstuk zal hierop nader worden ingegian.

\section{De onderkant van de arbeidsmarkt}

Naast de verbetering van de arbeidsmarktperspectieven voor het hoger onderwijs dic zich enkele jaren geleden inzette en de versteviging van de positie voor een grom aantal opleidingstypen op het MBO/leerlingwezen-niveau, is bij de prognoses tot 2002 ook een aantal VBO-opleidingen te vinden met goede perspectieven voor schoolverlaters. Nadere analyse van deze positieverbetering van degenen die met een VBO-diploma de arbeidsmarkt betreden, wijst echter uit dat er voor deze opleidingstypen geen sprake is van een toenemende vraag. De oorzaak voor de verbetering van het arbeidsmarktperspectief ligt hier geheel aan de aanbodkant. Steeds minder leerlingen betreden de arbeidsmarkt met alleen een VBO-diploma, terwijl bovendien veel van hen na enkele jaren alsnog een diploma op MBO/leerlingwezen-niveau behalen.

24 In tabel 1.13 van de Statistische Bijlage wordt een volledig overzicht gegeven van de opleidingsty pen waarvoor grote tot zeer grote knelpunten in de personeelsworziening worden verwacht 
Het mes snijdt hierbij aan twee kanten. Doordat voor steeds meer functies minimaal een diploma uit het middelbaar beroepsonderwijs wordt gevraagd, verbetert de positie van deze groep bijscholers aanzienlijk. Het afnemend aantal functies dat nog beschikbaar is voor de lagere opleidingsniveaus komt daardoor terecht bij de groep die kennelijk niet in staat is dit zogenaamde 'startkwalificatie'-niveau te behalen. Deze ontwikkelingen van vraag en aanbod leiden er toe dat de arbeidsmarktpositie van schoolverlaters op dit opleidingsniveau niet verslechtert. Andere ontwikkelingen laten echter zien dat de positie van deze laag geschoolden niet zonder meer rooskleurig genoemd kan worden.

Ten eerste is bij de ongeschoolden en veel opleidingstypen op VBO-niveau sprake van een krimpende werkgelegenheid. Deze manifesteert zich echter met name in een hoge arbeidsmarktuitstroom van laag geschoolde werkenden op een vaak relatief jonge leeftijd. Deze uitstroom creëert weliswaar tot op zekere hoogte vervangingsvraag voor schoolverlaters met een lagere opleiding, maar als de situatie op de arbeidsmarkt in dit opzicht niet verandert, hebben ook deze schoolverlaters slechts een perspectief op een kortstondig verblijf op de arbeidsmarkt. Alleen door verder te leren via het leerlingwezen of door via andere opleidingstrajecten een startkwalificatie voor de arbeidsmarkt te behalen, kan men dit ongunstige langere-termijn-perspectief waarschijnlijk ontlopen.

Daarnaast blijkt dat de 'ongeschoolden' met alleen basisonderwijs steeds sterker afhankelijk worden van functies waarvoor terdege bepaalde kwalificaties zijn vereist. In een aantal gevallen zal het gebrek aan onderwijs in dit opzicht gecompenseerd kunnen worden door werkervaring, maar in andere gevallen zal er een spanning ontstaan tussen de competenties waarover de betrokkene beschikt en de vaardigheden die het werk vereist. Zelfs als informele 'on-the-job training' de betrokkenen op een voldoende hoog werkniveau heeft gebracht, kan een gebrek aan formele kwalificaties en het in onvoldoende mate beschikken over bredere kwalificaties, waardoor de verworven kennis ook in andere functies kan worden benut, de positie van de laaggeschoolden erg kwetsbaar maken.

\section{De arbeidsmarktperspectieven van allochtonen}

Lit tabel 5.2 blijkt dat allochtonen op basis van hun opleidingsachtergrond een duidelijk minder goed arbeidsmarktperspectief hebben dan de gemiddelde in Nederland woonachtige beroepsbevolking. Wel blijkt uit de lage ITA-waarden dat ook allochtonen zullen profiteren van de goede arbeidsmarktperspectieven die voor veel opleidingstypen worden verwacht. Het valt echter op dat er ook tussen de diverse groepen allochtonen grote verschillen bestaan. De arbeidsmarktpositie van allochtonen uit landen die worden genoemd in de Wet Bevordering Arbeidsdeelname Allochtonen (WBEAA) is vaak slechter dan de positie van Nederlanders en allochtonen die overwegend uit westerse landen afkomstig zijn. Turken en Marokkanen zullen het minst profiteren van de verwachte gunstige arbeidsmarktperspectieven voor veel opleidingstypen. Dit komt in belangrijke mate doordat zij vaak een opleidingsachtergrond hebben waarvoor de werkgelegenheid krimpt. Surinamers en Antillianen hebben daarentegen een wat beter perspectief. Allochtonen afkomstig uit het voormalige Joegoslavië blijken, vooral door het hoge gemiddelde opleidingsniveau van deze groep, de beste perspectieven te hebben van de allochtonen afkomstig uit de WBEAA-landen. 
Allochtonen uit niet-WBEAA-landen hebben opmerkelijk genoeg gemiddeld genomen iets betere perspectieven dan autochtone Nederlanders. Dit geldt met name voor allochtonen afkomstig uit de overige E.U.-landen, Oost-Europa en de Verenigde Staten. Enerzijds zijn de perspectieven van deze groepen beter doordat het hier gaat om personen met een relatief hoog opleidingsniveau. Anderzijds is er wellicht sprake van een 'pull-effect'. Opleidingstypen met goede perspectieven trekken mensen uit deze landen aan. Toch zijn er ook bij de allochtonen afkomstig uit de niet-WBEAA-landen groepen met een wat minder gunstige arbeidsmarktpositie. Zo hebben allochtonen die afkomstig zijn uit de zuidelijke E.U.-landen Portugal, Spanje, Italië en Griekenland arbeidsmarktperspectieven die vergelijkbaar zijn met de gemiddelde perspectieven van allochtonen afkomstig uit de WBEAA-landen. Ook de arbeidsmarktperspectieven van Tunesiërs, Algerijnen en Chinezen zijn minder gunstig. Evenals bij de allochtonen afkomstig uit de WBEAA-landen zijn de minder goede arbeidsmarktperspectieven van deze groepen allochtonen hoofdzakelijk het gevolg van hun lagere opleidingsniveau. Dat impliceert dat deze allochtonen veelal in beroepen werkzaam zijn waarin hun opleidingsachtergrond steeds minder wordt gevraagd.

Tabel 5.2

Gemiddelde jaarlijkse uitbreidingsvraag en gemiddelde indicator toekomstige arbeidsmarktperspectieven (ITA) naar land van herkomst

Land van herkomst

\section{Uitbreidingsvraag per opleidingstype}

\section{Uitbreidingsvraag per beroepsgroep}

ITA
Niet-WBEAA-landen

Nederland

Zuidelijke E.U.-landen

Overige E.U.-landen

Oost-Europa

Verenigde Staten

Indonesië/Indische Nederlanders

Tunesië/Algerije

China

Totaal niet-WBEAA-landen (excl. Nederland)

Turkije

Marokko

Suriname

Ned. Antillen/Aruba

Voormalig Joegoslavië

Totaal WBEAA-landen

\section{1,8}

1,5

3,1

3,7

4,2

2,1

1,6

0,7

2,4

$-0,6$

$-0,7$

1,3

1,9

2,9

0.9
1,6

1,5

1,8

1,9

2,1

1,8

1,6

1,4

1,8

1,3

1,5

1,7

1,7

1,3

1,5
0,96

0,97

0,93

0,92

0,91

0,95

0,97

0,99

0,95

1,01

1,02

0,97

0,96

0,93

0,98

Bron: ROA

Over het algemeen zijn allochtone arbeidskrachten oververtegenwoordigd an de onderkant van de arbeidsmarkt. Het gaat dan vooral om ongeschoolden, MAVo'ers en VBO'ers elektro en mechanische techniek. Wel lijkt het gemiddelde opleidingsniveau 
van de werkzame allochtonen de laatste jaren enigszins te stijgen. Het percentage allochtonen met een VBO-opleidingsachtergrond blijft constant of daalt, terwijl het percentage allochtonen bij een aantal MBO-opleidingen stijgt.

\section{Hoge arbeidsmarktinstroom en slechte arbeidsmarktperspectieven}

Voor slechts enkele opleidingstypen zijn de arbeidsmarktperspectieven voor 2002 matig of slecht. Bij vijf opleidingstypen is er sprake van slechte perspectieven, terwijl voor acht opleidingstypen de perspectieven matig zijn. Opvallend is echter dat met name bij deze opleidingstypen veelal sprake is van een hoge of erg hoge instroom van schoolverlaters. Tabel 5.3 laat zien dat alle opleidingstypen met een slecht perspectief gekenmerkt worden door een hoge of zeer hoge arbeidsmarktinstroom. Bij de opleidingstypen met matige perspectieven heeft 63\% een hoge of erg hoge instroom. Overigens blijkt dat een erg hoge instroom niet automatisch leidt tot slechte of matige perspectieven. Bij de meeste opleidingstypen is ondanks een (erg) hoge instroom van schoolverlaters het arbeidsmarktperspectief goed of redelijk.

Tabel 5.3

\section{De relatie tussen arbeidsmarktperspectief en instroom schoolverlaters}

Instroom schoolverlaters

Erg laag

Laag

Gemiddeld

Hoog

Erg hoog

\section{Zeer goed

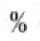

Goed

Goed $\begin{gathered}\text { Arbeidsmarktperspectief } \\ \%\end{gathered} \quad$ Redelijk

13

44

25

19
3

19

$\begin{array}{lll}50 & 54 & 38\end{array}$

$\begin{array}{ll}22 & 9\end{array}$

$\begin{array}{lll}5 & 36 & 13\end{array}$
Slecht $\%$ 40

60

Bron: ROA

Beperking van de hoge onderwijsinstroom in de opleidingen met slechte perspectieven lijkt een belangrijke bijdrage te kunnen leveren aan het verbeteren van de arbeidsmarktperspectieven voor deze opleidingen. Een dergelijke beperking van de instroom kan in de eerste platts worden bevorderd door bij de studie- en beroepskeuzevoorlichting ook de arbeidsmarktperspectieven van de verschillende opleidingen voor het voetlicht te brengen. Verwacht mag worden dat als leerlingen en hun ouders doordrongen zijn van de matige of slechte perspectieven van een opleiding, de belangstelling voor de desbetreffende richting af zal nemen.

Om zeer extreme discrepanties tussen vraig en aanbod op de arbeidsmarkt te beperken zou ook overwogen kunnen worden een instroombeperking in te stellen. Een dergelijke arbeidsmarktfixts kan zeer sterke schommelingen in de instroom en het arbeidsmarktperspectief - de zogenaamde varkenscyclus - stabiliseren. Hierbij dient men zich wel af te vragen welke alternatieven er voor de desbetreffende groep leerlingen beschikbaar zijn. Als de alternatieven voor leerlingen die niet worden toegelaten tot een opleidingstype met slechte perspectieven, zelf ook slechte perspectieven hebben, zal een dergelijke instroombeperking per saldo niet leiden tot een verbetering van de artheidsmarktperspectieven voor deze leerlingen. De consequenties kunnen zelfs nog 
negatiever zijn als de instroombeperking er toe zou leiden dat een bepaalde groep leerlingen überhaupt geen beroepsopleiding meer zou volgen, of een studie gaat kiezen die minder aansluit bij hun interesse en capaciteiten, waardoor er sprake zal zijn van een hogere studie-uitval. In dat geval leidt een instroombeperking tot een verslechtering in plaats van tot een verbetering van het arbeidsmarktperspectief voor deze leerlingen.

Bovendien leidt een arbeidsmarktfixus er toe dat leerlingen die niet worden toegelaten een alternatieve opleiding zullen kiezen. Ook hier geldt dat als de alternatieven die voor handen zijn geen betere perspectieven bieden dan de opleiding waarvoor de fixus wordt ingesteld, de verbeterde arbeidsmarktsituatie bij de ene opleiding tot een toename van de problemen bij andere opleidingen leidt. Een eventueel in te stellen arbeidsmarktfixus zou daarom altijd in het licht van het keuzegedrag in zijn totaliteit bezien moeten worden. Een goed functionerende arbeidsmarkt is bovendien gebaat bij een beperkt gebruik van de arbeidsmarktfixus ${ }^{25}$. Als een arbeidsmarktfixus voor een bepaalde opleiding gedurende lange tijd wordt ingesteld, ontneemt deze fixus de arbeidsmarkt haar aanpassingsvermogen. Toekomstige leerlingen krijgen in dat geval immers geen signalen meer van de markt, die hen tot een keuzeverandering aan zouden kunnen zetten. Hierdoor zou de arbeidsmarktfixus tot in lengte van dagen noodzakelijk kunnen blijven.

Wanneer de arbeidsmarktfixus te lang blifft bestaan, kan de beperking van de leerlingeninstroom van het desbetreffende opleidingstype er ook toe leiden dat de vereiste wervingsinspanningen van werkgevers zullen toenemen. Hierdoor zullen werkgevers in hun afweging tussen de verschillende opleidingstypen waaruit zij kunnen werven, voor functies waarvoor er duidelijke substitutiemogelijkheden bestaan, steeds vaker arbeidskrachten met een andere opleidingsachtergrond prefereren. De vraag zoals die gepercipieerd wordt voor het opleidingstype waarvoor een arbeidsmarktfixus is ingesteld, blijft dan structureel lager dan het geval zou zijn bij een niet-gereguleerde markt. Ook hierdoor kan de vermeende noodzaak tot het instellen van de arbeidsmarktfixus blijven bestaan. Bovendien zal het beroependomein van de desbetreffende opleiding beperkt blijven tot die functies waarvoor de desbetreffende opleidingsachtergrond specifiek vereist is. Dit beperkte beroependomein leidt daarmee tot een structurect zwakkere positie van de desbetreffende opleiding. Een arbeidsmarktfixus als instrument om vraag en aanbod met elkaar in evenwicht te brengen zou daarom alleen ingeret moeten worden als er sprake is van een plotselinge verschuiving op de arbeidsmarkt meestal vanwege een sterke toename in het aanbod - terwij daarbij bovendien een instroomniveau gekozen zou moeten worden dat arbeidsmarktaanpassingen niet structureel zal belemmeren.

\section{Veranderingen in het onderwijsaanbod en macrodoelmatigheid}

Een arbeidsmarktfixus is als instrument met name gericht op het terugdringen van de instroom van opleidingstypen met slechte perspectieven. Omgekeerd kan het beleid ook gericht worden op het bevorderen van de instroom in opleidingstypen met gocede

25 Zie L. Borghans. A. de Grip, Numerus fixus en de arbeidsmarkt, in: Iiconomisch Statistische Berichten, 5 februari 1997. pp. 111-113. 
of zeer goede perspectieven. Het zonder meer vergroten van het onderwijsaanbod zal echter niet altijd de gewenste effecten sorteren. Een vergroting van de opleidingscapaciteit garandeert immers niet dat deze capaciteit ook benut zal worden. Een verruimde geografische spreiding of de introductie van een opleidingsvariant die op dat moment nog niet wordt aangeboden, zal doorgaans wel de instroom voor het desbetreffende opleidingstype verhogen, doordat mobiliteitsdrempels worden weggenomen of beter ingespeeld kan worden op de interesse of capaciteiten van leerlingen.

Een vraag die zich voordoet bij een dergelijke uitbreiding van het onderwijsaanbod is echter welke leerlingen hiermee worden aangetrokken. Als een verhoogde geografische spreiding er alleen toe leidt dat leerlingen dezelfde opleiding minder ver van huis kunnen volgen, of als de extra belangstelling voor een nieuwe opleiding met goede perspectieven leerlingen trekt die anders een opleiding met zeer goede perspectieven hadden gekozen is de 'macrodoelmatigheid' van de nieuwe opleiding ondanks de gunstige arbeidsmarktperspectieven beperkt.

Nieuw aanbod van opleidingen zal daarom met name baat hebben wanneer er leerlingen worden aangetrokken die anders een opleiding zouden kiezen met duidelijk slechtere perspectieven. Zo kan de keuze voor opleidingen met slechte perspectieven het gevolg zijn van geografische belemmeringen. Ook kan de oorzaak liggen in de capaciteiten en interesse van de leerlingen. Een nieuwe opleiding die door het aanbieden van een leerweg voor leerlingen met beperkte capaciteiten, deze leerlingen toch adequaat opleidt in een richting met goede perspectieven, kan in dat opzicht een zeer waardevolle aanvulling zijn van het opleidingsaanbod. Op vergelijkbare wijze kan een nieuwe opleiding in een richting met goede perspectieven, die door een andere invulling van het onderwijs meer belangstelling van een bepaalde groep leerlingen weet te wekken, een verhoogde instroom bewerkstelligen. Een duidelijk voorbeeld daarvan zijn technische opleidingen met (zeer) goede arbeidsmarktperspectieven die meer meisjes weten aan te trekken. Vanuit deze optiek is het overigens niet in de eerste plaats van belang dat er sprake is van een zeer goed arbeidsmarktperspectief, maar wordt de aansluiting onderwijs-arbeidsmarkt met name verbeterd als leerlingen die aanvankelijk zouden kiezen voor een richting met minder goede perspectieven nu kiezen voor een opleiding met een beter perspectief.

Natast het arbeidsmarktperspectief, dat gebaseerd is op de verwachte ontwikkelingen in vratag en atanbod, kan het onderwijsbeleid ook de structurele positie van opleidingen als richtlijn nemen. Zoals in hoofdstuk 3 werd aangegeven, zijn er bepaalde opleidingen die een hoge mate van conjunctuurgevoeligheid combineren met beperkte uitwijkmogelijkheden. Veranderingen in het onderwijs, watardoor de opleiding verbreedt en daardoor toegang verschaft tot een breder beroependomein, kan deze kwetsbaarheid verminderen. Omgekeerd kunnen ontwikkelingen aan de vraagkant van de arbeidsmarkt leiden tot een behoefte aan personeel met zeer specifieke vaardigheden. Hierdoor kan het wenselijk zijn een meer specialistische opleiding te starten. Hierbij dient altijd wel overwogen te worden in hoeverre de vraag naar deze vakspecialisten stabiel is, ondat de voordelen van het specialisme op moeten wegen tegen de risico's die met een dergelijke specialisatie worden gelopen. 


\section{Scholingsbeleid}

De verwachte krapte op de arbeidsmarkt voor een groot aantal opleidingstypen zou een belangrijke hinderpaal kunnen gaan vormen voor de internationale concurrentiepositie van de Nederlandse economie. Gezien de omvang van de voor de prognoseperiode verwachte knelpunten in de personeelsvoorziening voor een groot aantal opleidingstypen en de beperkte mogelijkheid om hierop door verschuivingen in de arbeidsmarktinstroom vanuit het initiële onderwijs in te spelen, is het evident dat een belangrijke impuls zal moeten worden gegeven aan het bij- of omscholen van het beschikbare arbeidsaanbod. Ter afsluiting van dit hoofdstuk zal een indicatie worden gegeven van de reikwijdte die een dergelijk scholingsbeleid zou moeten hebben om de verwachte tekorten te beperken.

In totaal is er bij de opleidingstypen met grote tot zeer grote tekorten in de personeelsvoorziening een aanbodtekort van 445.000 arbeidskrachten. Tabel 5.4 geeft een eerste indicatie van het mogelijke arbeidsaanbod dat via een bij- of omscholingstraject gerecruteerd zou kunnen worden voor moeilijk vervulbare functies. Het gaat hierbij om een macro-beeld, waarbij er ook niet is nagegaan in hoeverre de noodzakelijke scholing voor de desbetreffende groepen een reële optie is gezien hun huidige opleidingsachtergrond $^{20}$. In de tabel is een onderscheid gemaakt tussen het aanbodoverschot bij de opleidingstypen waarbij er geen sprake is van een goed arbeidsmarktperspectief, de langdurig werklozen en de niet-participerende potentiële beroepsbevolking. Bij de laatste twee groepen is bovendien een onderscheid gemaakt tussen degenen die een opleidingsachtergrond hebben waarvoor het arbeidsmarktperspectief goed is en degenen waarvoor dat niet het geval is.

Uit de tabel blijkt dat er een aanbodoverschot van circa 155.000 mensen is bij de opleidingen waarbij er geen sprake is van een goed arbeidsmarktperspectief. 1)arbij moet bedacht worden dat de grote knelpunten in de personeelsvoorziening zich valak voordoen bij de hoger opgeleiden, terwijl de aanbodoverschotten zich concentreren bij de. lager opgeleiden. Desalniettemin kwam in paragraaf 4.4 naar voren dat er bij vecl opleidingsperspectieven met minder gunstige arbeidsmarktperspectieven terdege reële opleidingsalternatieven zijn met goede arbeidsmarktperspectieven. Een belangrijke doelgroep voor het bij- of omscholingsheleid is ongetwijfeld de groep langdurig werklozen. Het is opmerkelijk dat bijna de helft van de langdurig werklozen ecen opleidingsachtergrond heeft waarvoor de arbeidsmarktperspectieven goed zijn. Hel gata hier om 110.000 mensen. Daarnaast zijn er ruim 117.000 langdurig werklozen mex een opleidingsachtergrond watrvoor cke arbeidsmarktperspectieven niet goed zijn. Voor cke groep zal de afstand tot een succesvolle arbeidsmarktintrede vanzelfsprekend groter zijn.

26. In A. de Grip. et al. Werkgelegenhesid en scholing 1996, ROA-R-1997/1, Matastricht, 1907 worde wel nader ingegaan op de opleidingstypen die vor bepalde probleemgrexpen cen reed perspectiel bieden op het vinden van emplosi door bij- of omscholing. 
Tabel 5.4

Mogelijke doelgroepen voor bij- of omscholing binnen de potentiële beroepsbevolking

\section{Opleidingsachtergrond Opleidingsachtergrond} met goed perspectief met aanbodoverschot

Aanbodtekort

Aanbodoverschot

Langdurig werklozen

Niet-participerenden ${ }^{*}$
445.000

977.000
Totaal

227.000

2.644 .000

" exclusief degenen die participeren in het dagonderwijs

Bron: ROA

Ten slotte wordt in tabel 5.4 de omvang weergegeven van de niet-participerende potentiële beroepsbevolking. Het is bekend dat dit een zeer groot deel van de potentiële beroepsbevolking betreft. Voor een deel van deze groep zal de wil en de noodzaak tot arbeidsmarktintrede gering zijn, of in het geheel niet aanwezig zijn. Gezien de zeer grote omvang van deze groep kunnen de niet-participerenden waarschijnlijk toch een belangrijke doelgroep zijn voor het wervingsbeleid voor opleidingstypen met grote knelpunten in de personeelsvoorziening. De analyses in hoofdstuk 4 lieten echter zien dat voor een groot aantal opleidingstypen een hoge of zelfs volledige inzet van de nietparticiperenden met de desbetreffende opleidingsachtergrond onvoldoende zou zijn om de tekorten in de personeelsvoorziening op te heffen. Ook bij het inzetten van deze groep niet-participerenden zou daarom in een groot aantal gevallen additionele scholing vereist zijn. 


\section{Enkele centrale begrippen}

\section{Allochtoon}

Het begrip allochtoon wordt in dit rapport gehanteerd volgens de CBS-definitie. Deze definitie houdt in dat iedereen die een niet-Nederlandse nationaliteit bezit, of die buiten Nederland is geboren, allochtoon is. De allochtonen worden onderscheiden naar land van herkomst. Van speciaal belang vanuit beleidsoogpunt zijn de allochtonen uit de landen die genoemd worden in de Wet Bevordering Evenredige Arbeidsdeelname Allochtonen (WBEAA). Deze landen zijn: Aruba, Nederlandse Antillen, Ethiopië, Irak, Iran, voormalige Joegoslavië, Marokko, Somalië, Suriname, Turkije en Vietnam. Op grond van deze wet zouden echter ook kinderen van allochtonen tot de doelgroep gerekend moeten worden, ongeacht zij een niet-Nederlandse nationaliteit bezitten.

\section{Arbeidsvolume}

Het totaal aantal arbeidsjaren, waarbij is uitgegaan van een werkweek van 40 uur.

\section{Baanopeningen}

De totale vraag naar nieuwkomers op de arbeidsmarkt, zoals deze is bepaald door de werkgelegenheidsgroei (positieve uitbreidingsvraag) en de vervangingsvraag.

\section{Bedrijfssector}

Alle voorkomende bedrijven zijn ingedeeld in een aantal clusters. De in dit rapport gepresenteerde informatie is veelal verbijzonderd naar 35 bedrijfssectoren. De prognoses van de uitbreidingsvraag zijn slechts verbijzonderd natar 13 bedrijfssectoren. 1) e laatste indeling komt overeen met de door het Centraal Planbureau bij de sectorprognoses gehanteerde bedrijfssectorindeling.

\section{Beroepsgroep}

Alle voorkomende beroepen zijn ingedeeld in een aantal clusters. In dit rapport wordt hoofdzakelijk uitgegaan van 127 beroepsgroepen. Deze kunnen verder worden geclusterd tot 11 beroepssectoren. Voor 123 beroepsgroepen kon een prognose van de loekomstige vraagontwikkelingen op de arbeidsmarkt worden opgesteld.

\section{Publicatie:}

Centraal Bureau voor de Statistiek, Standaard Beroepenclassificalie 1992, Sdu, I)en Haag, 1993.

27 Een meer specifieke toelichting op de gehanteerde definities in het prognosemoxtel is te vinden in L. Borghans et. al. Methodiek arbeidsmarktprognoses en -indicatoren 1997-20(1)2. R()A-W. 1907 (6. Maastricht. 1997. 
Beroepsbevolking

De beroepsbevolking omvat de werkenden en werkzoekenden zonder baan. Iedereen met een leeftijd tussen de 15 en 65 jaar, die minstens 12 uur per week betaalde arbeid verricht of zou willen verrichten wordt tot de beroepsbevolking gerekend. Als men reeds meer dan 12 uur per week werkt, wordt men tot de werkzame beroepsbevolking gerekend. Werkt men niet of minder dan 12 uur, maar wil men wel minstens 12 uur per week betaalde arbeid verrichten, dan behoort men tot de werkloze beroepsbevolking.

\section{Publicatie:}

Centraal Bureau voor de Statistiek, Enquête Beroepsbevolking 1996, Voorburg/Heerlen, 1997.

\section{Conjunctuurgevoeligheid}

De conjuncturgevoeligheid van de werkgelegenheid heeft betrekking op de mate waarin de werkgelegenheid in een beroepsklasse, of voor mensen met een bepaalde opleidingsachtergrond, gevoelig is voor veranderingen van de economische situatie. Deze indicator geeft daarmee de mate van werkzekerheid aan. De conjuncturgevoeligheid wordt bepaald door de sectorale werkgelegenheidsfluctuaties in het verleden te relateren aan de mate waarin een beroepsgroep momenteel in de verschillende bedriffssectoren is vertegenwoordigd. Hierbij wordt rekening gehouden met het feit dat niet ieder beroep even sterk meefluctueert met de werkgelegenheidsschommelingen van de bedrijfssector.

\section{Flexibele arbeidsrelatie}

Van een flexibele arbeidsrelatie is sprake bij uitzendkrachten, oproepkrachten, invalskrachten, contracten zonder een vast aantal arbeidsuren en indien geen vast dienstverband is overeengekomen. Een arbeidscontract wordt als niet-vast beschouwd als de contractuele termijn korter is dan een jaar en er geen vooruitzicht is op een vast dienstverland.

Instroom van schoolverlaters

Het aanbod van nieuwe arbeidskrachten op de arbeidsmarkt, zoals deze is bepaald door de verwachte uitstroom van schoolverlaters uit het initiële dagonderwijs, de schoolverlaters van het deeltijdonderwijs, het niet-reguliere voltijdonderwijs en de beroepsgerichte volwasseneneducatie.

\section{Publicaties:}

H. Berendsen, R.J.P. Dekker, A. de Grip, P.J.E. van de Loo (1992), Prognose arbeidsmarktinstroom can schoolverlaters per opleidingstype. ROA-W-1992/2, Maastricht

A. Matheeuwsen, A. de Grip, De doorstroom van het reguliere naar het niet-reguliere onderuijs, ROA-W-1997/4, Maastricht. 


\section{Knelpunten in de personeelsvoorziening}

Als de vraag naar werkenden met een bepaalde opleidingsachtergrond groter is dan het aanbod kunnen knelpunten in de personeelsvoorziening verwacht worden. Vergelijkbaar met de indicator toekomstige arbeidsmarktsituatie (ITA) geeft de indicator van de toekomstige knelpunten in de personeelsvoorziening (ITKP) deze vraag-aanbod-spanning aan. Verschil met de ITA is dat bij de ITKP de uitstroom van werkenden als gevolg van een krimpende werkgelegenheid is meegerekend in de vraag, ondat verwacht mag worden dat bij knelpunten in de personeelsvoorziening deze (gedwongen) uitstroom kan worden afgeremd of elders werk zou kunnen vinden. Naarmate de waarde van de indicator lager wordt, zijn de verwachte knelpunten groter.

\section{Onderbenutting}

Een indicatie van de mate warin arbeidskrachten werkzaam zijn op een functieniveau dat lager is dan hun opleidingsniveau. In hoofdstuk 3 is de onderbenutting vastgesteld door de schoolverlaters zelf te laten aangeven welk opleidingsniveau vereist is voor de door hen uitgeoefende functie. Daarentegen is in paragraaf 4.2 de onderbenutting afgeleid van de typering van het vereiste opleidingsniveau van de verschillende beroepen op basis van de opleidingsachtergrond van de werkenden.

\section{Publicaties:}

L. Borghans, A. de Grip, W. Smits en H. Zuurbier, Het beroependomein van opleidingen, ROA-R- 1997/2, Maastricht, 1997.

A. de Grip, R.K.W. van der Velden, M.H. Wieling (1993), De inpassing van schoolverlatersinformatie in het ROA-informatiesysteem onderwijs-arbeidsmarkt, ROA-R-1993/9, Maastricht.

\section{Opleidingstype}

Alle voorkomende opleidingen zijn samengevoegd tot een aantal clusters. In dit rapport worden 104 opleidingstypen onderscheiden. Voor 98 opleidingstypen kon een prognose van de toekomstige vraag- en aanbodontwikkelingen op de arbeidsmarkt worden opgesteld.

\section{Participatie(graad)}

Er wordt onderscheid gemaakt tussen de netto- en de bruto-participatiegraad. De nettoparticipatiegraad is gedefinieerd als de werkzame beroepsbevolking gedeeld door de totale bevolking tussen 15 en 65 jaar. Bij de bruto-participatiegraad gat het om de gehele beroepsbevolking, die zowel werkzamen als werklozen omvat, als aandeel van de totale bevolking tussen de 15 en 65 jaar.

\section{Substitutie-effect (passief en actief)}

Als gevolg van discrepanties tussen vraag en aanbod op de arbeidsmarkt treden er verschuivingen op in de werkgelegenheidsstructuur. Schoolverlaters in een aanbodoverschotsituatie kunnen anders opgeleiden gaan verdringen, terwijl werkgevers dic te 
kampen hebben met een tekortschietend arbeidsaanbod, personen met een andere opleidingsachtergrond kunnen gaan werven. De vraag die hierdoor verloren gaat of ontstaat wordt aangeduid als het passieve-substitutie-effect. Als het passieve substitutieeffect positief is gaat het om extra baanopeningen als gevolg van tekorten bij andere opleidingen. Een negatief substitutie-effect duidt daarentegen op een verlies aan baanopeningen, omdat men verdrongen wordt door andere opleidingen. Het actieve-substitutie-effect geeft - als het positief is - aan in hoeverre werkenden met een opleidingsachtergrond waarvoor er een aanbodoverschot is door een verhevigde concurrentie alsnog werk zullen vinden door arbeidskrachten met een andere opleidingsachtergrond te verdringen. Een negatieve actieve substitutie geeft daarentegen aan welke werkgelegenheid niet meer vervuld zal worden als gevolg van de verwachte aanbodtekorten.

\section{Publicaties:}

L.Borghans en J.A.M. Heijke, Forecasting the Educational Structure of Occupations: A Manpower Requirement Approach with Substitution, Labour, vol. 10, no. 1, p. 151-192, 1996.

A. de Grip, L. Borghans, W. Smits, Future developments in the job level and domain of highly-skilled workers, in: H. Heijke, L. Borghans (eds.), Towards a transparent labour market for educational decisions, Avebury, Aldershot (verschijnt binnenkort).

\section{Substitutiemogelijkheden bij de personeelswerving}

De mate warin werkgevers voor een bepaald beroep arbeidskrachten kunnen aantrekken met een uiteenlopende opleidingsachtergrond, zodat ze niet afhankelijk zijn van het arbeidsaanbod van een bepaald opleidingstype. De substitutiemogelijkheden worden bepaald met behulp van een spreidingsindex.

\section{Toekomstig arbeidsmarktperspectief}

Het toekomstig arbeidsmarktperspectief geeft de verhouding tussen aanbod en vraag in de prognoseperiode voor een opleidingstype weer. De vraag- en aanbodprognoses zijn gebaseerd op de actuele arbeidsmarktpositie van een opleiding. Als het arbeidsmarktperspectief van een opleiding slecht is, betekent dit dat er de komende jaren veel meer aanbod van nieuwkomers is dan baanopeningen. Hierdoor zal de arbeidsmarktpositie galan verslechteren. Deze verslechtering kan een hogere werkloosheid betekenen, maar door aanpassingsprocessen op de arbeidsmarkt kan dit ook leiden tot het moeten alanvalarden van banen op een lager niveau, een lagere beloning en meer tijdelijke contracten. Omgekeerd zal een goed perspectief tot een grotere kans op werk, maar ook tot een verbeterde positie op andere punten leiden. Het toekomstig arbeidsmarktperspectief per opleidingstype wordt bepaald door middel van de indicator toekomstige arbeidsmarkiperspectieven (ITA), die is gedefinieerd als de verhouding tussen enerzijds de verwachte instroom van schoolverlaters en het aantal kortdurig werklozen en anderzijds de verwachte baanopeningen en de passieve substitutievraag. Naarmate de watarde van de indicator hoger is wordt het perspectief slechter.

Publicatie:

L. Borghans et al., Methodiek arbeidsmarktprognoses en -indicatoren 1997-2002, ROAW-1997/6, Malastricht, 1997. 


\section{Uitbreidingsvraag}

De vraag naar nieuwe arbeidskrachten die ontstaat door groei van de werkgelegenheid. Als er sprake is van een werkgelegenheidsdaling, is de uitbreidingsvraag negatief.

\section{Publicaties:}

L. Borghans, H. Heijke, Het voorspellen van de beroepenstructuur van bedrijfstakken binnen bet kader van bet Athena-model, ROA-W-1994/1, Maastricht.

L. Borghans, H. Heijke, Forecasting the Educational Structure of Occupations: A Manpower Requirement Approach with Substitution, Labour; vol. 10, no. 1, p. 151-192, 1996.

\section{Uitwijkmogelijkheden}

De mate waarin arbeidskrachten met een bepaalde opleidingsachtergrond of met een bepaald beroep terecht kunnen komen in andere beroepsgroepen op een aansluitend of hoger functieniveau, respectievelijk in andere bedrijfsklassen. Deze maatstaf geeft daarmee aan in hoeverre arbeidskrachten afhankelijk zijn van de arbeidsmarktsituatie in een bepaald beroep of een bepaalde bedrijfssector. De uitwijkmogelijkheden worden bepaald met behulp van een spreidingsindex. Deze index geeft een indicatie van het aantal beroepsgroepen of bedrijfsklassen waarnaar men kan uitwijken.

\section{Publicatie:}

L. Borghans, H. Heijke, Flexibility and the Structure of the Dutch Labour Market, in: H. Heijke, L. Borghans (eds.), Towards a transparent labour market for educational decisions, Avebury, Aldershot (verschijnt binnenkort).

\section{Upgrading}

Door een toenemende complexiteit van de te verrichten werkzaamheden kunnen er voor een bepaald beroep door werkgevers hogere opleidingseisen worden gesteld. In dat geval spreekt men van upgrading van de kwalificatie-eisen. Overigens kan ook een verschuiving van de werkgelegenheid van lagere naar hogere beroepen als een upgratdingsproces worden getypeerd.

\section{Vakspecifiek}

Het beroepsterrein van de werkenden met een bepaalde opleidingsachtergrond kan worden opgesplitst in een aan de gevolgde opleiding verwant vakspecifiek beroepsterrein en het niet-lakspecifiek beroepsterrein. Van een vakspecifiek beroepsterrein is sprake als het overgrote deel van de werkenden de desbetreffende opleidingsrichting heeft gevolgd. Beroepen waarin werkenden een sterk uiteenlopende opleidingsachtergrond hebben, worden daarentegen als 'niet-vakspecifiek' getypeerd. Bij de analyse van de vereiste vaardigheden wordt ook vakspecifieke vaardigheden onderscheiden. De invalshoek is hier geheel anders. Vakspecifieke vaardigheden heblxen betrekking op kwalitatieve, technische of handvaardigheden. 